Historic, Archive Document

Do not assume content reflects current scientific knowledge, policies, or practices. 



\section{The "Cream" Of The Crop}

$5 \%$ discount (and free delivery for points east of the Mississippi River) is allowed on orders for bulbs amounting to $\$ 1.00$ or more and accompanied by cash reaching us not later than July 15,1920 . (Such orders can be packed specially in Holland where labor is cheap).

\section{Bulbs and Seeds; Free Delivery Terms}

We Deliver Free, Bulbs amounting to $\$ 1.00$ or more, cash accompanying order, in the U. S. A. east of the Mississippi River. Delivery is made by parcel post, or express at our option. If prepayment to points west of the Mississippi River, Canada and the outlying possessions of the U.S. A. is desired, $10 \%$ of the amount of the order must be added. Canadian import duties to be paid by the purchaser.

We Deliver Free, if cash accompanies the order All Lawn Grass Mixtures and Flower Seeds anywhere in the United States and its possessions, and Canada. Delivery is made by parcel post, express, or freight at our option. Canadian import duties to be paid by purchaser.

We Do Not Pay Transportation charges on miscellaneous garden supplies, implements, fertilizers, insecticides, plants, clumps, grain and grass seeds (other than Lawn Grass mixtures) nor on charge purchases (except flower seeds which are sent postpaid).

Charge Accounts are readily opened with responsible persons sending references with their orders. As a matter of convenience accounts are due on the 15th of the month following shipment. On such orders no discount is allowed and transportation, if prepaid, is charged to purchaser's account.

To Foreign Customers. We forward bulbs and seeds at customers' expense to any post office in foreign countries by International Parcel Post when mail routes are open. Domestic post rates, 8th Zone, apply to Alaska, the Canal Zone, Guam, Hawaii, Porto Rico and the Philippine Islands.

Cultural Directions. Upon request with each shipment of bulbs we send printed cultural directions.

Shipping Instructions. Please send full shipping instructions. State whether goods are to be shipped by express or parcel post, and by what route. In the absence of instructions, we will ship by whatever method and route we think best.

Time of Delivery. Bermuda Lilies arrive in August; Roman Hyacinths, Freesias, Candidum Lilies and Paper-White Narcissi in September; Dutch Bulbs, Hyacinths, Tulips, etc. in October or November. In ordering, please state whether you wish bulbs shipped as they arrive, or all in one shipment. In absence of instructions we will send all bulbs in one shipment, except Japanese Lilies and Lilyof-the-Valley, which will be shipped upon arrival, in November, December, or following Spring. Transportation conditions are still so unsettled that we cannot guarantee time of delivery, but, in the event of late delivery, northern orders will be shipped first and extreme southern ones last.

Remittances should be made by Draft on Bank, Post-Office Order, Registered Letter or Express Money Order. When Personal Checks are sent, please add 10 cents for exchange. Small sums may be sent in postage stamps of small denominations.

Gardeners' and Farmers' Situations. We have at all times the names of practical gardeners and farm managers in want of situations. If parties desiring such will write us, we shall be glad to put them in communication with men whom we deem suitable. We make no charge for this service.

Questions and Correspondence. We endeavor to answer promptly all letters of inquiry - which should be on separate paper from orders-but we cannot undertake the planning of entire gardens and grounds without charge.

Non-Warranty. Arthur T. Boddington Company, Inc., give no warranty, express or implied, as to description, quality, productiveness, or any other matter, of any Seeds, Bulbs or Plants, they send out, and will not be responsible for the crop. If the purchaser does not accept the goods on these terms, they are at once to be returned. All claims must be made within 5 days after receipt of goods.

\section{RARE AND UNUSUAL BULBS}

The following varieties are of great merit and are recommended to discriminating buyers with the assurance that each of them is a distinct advance over existing kinds.

\section{Hyacinths}

Prince Henry. Very fine new light rose; compact flower; good forcing variety.

Queen of the Whites. The finest, largest, purest white Hyacinth, extra show variety. .

Doz.

100

$\$ 3.50 \$ 26.00$

$7.00 \quad 52.00$

Duke of Westminster. Large, compact flower, the florets are deep purplish blue with velvety sheen, lighter blue to almost white in the center; good forcer

Washington Irving. New light blue, with lilac tinge .

\section{Single Early Tulips}

Enchantress. About the same size and habit as a large Proserpine, color wine red, each petal edged pale buff; charming color effect

Ibis. Tall, deep brilliant pink excellent forcer ... 1.50

President Taft. Beautiful silvery cerise on white undertone; very large flower.

White Beauty. The white sport of Pink Beauty; same perfect type plant but pure white.

\section{Double Tulips}

Velasquez. A large, golden yellow Murillo, having the same excellent qualities...

\section{Breeder Tulips}

Professor Schotel. Bright grayish violet......

Grand Monarque. Plum-purple, wine center

Superba. Chestnut brown with golden brown edge. 1.35

Yellow Perfection. Bronze yellow, shaded deep gold.

10.00

Xerxes

Large, light purplish-mauve

\section{Darwin Tulips}

Doz.

100

Duchess of Westminster (Yolande). Soft cerise, tinted salmon....................... $\$ 4.50 \$ 34.00$

Flamingo. Rosy flesh, pointed flower............ $1.20 \quad 8.50$

\section{Cottage Tulips}

Golden Spire. Enormous, deep golden yellow flower, finely edged orange-scarlet; reflexing petals........................... 1.20

La Ravissante (La Panachee). Rose, flaked on white ground, foliage variegated..............

Norham Beauty. Dull lilac, with golden bronze reflex.

\section{Narcissus}

Herbert Smith. Immense, deep yellow trumpet of noble form; large, light yellow perianth of fine substance.......................................... trumpet, with a finely frilled brim, well formed sulphur-yellow perianth.

Leedsii, White Lady. Pale canary cup with a broad, round, overlapping perianth.............

Leedsii, White Queen. Resembles a white Sir Watkin; pure white perianth, pale yellow cup with a frilled edge.

Poeticus Thelma. White perianth of great substance; large, overlapping petals, broad cup,

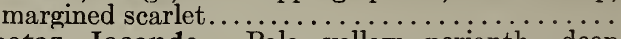

Poetaz Joconde. Pale yellow perianth, deep golden yellow cup. Produces four or five flowers on a stem. 


\section{How to Have Flowers in the House Thanksgiving}

\section{Day, Christmas and until Easter}

An abundant supply of flowers can be had in every home from Thanksgiving until Easter at comparatively small cost with no greater facilities than exist in every dwelling-house.

Chinese Sacred and Paper-White Narcissi can be bloomed by Thanksgiving, and are perhaps the most satisfactory bulbs that can be grown in a sunny window for Winter flowers. Cultural Directions. Plant the bulbs in shallow pans or boxes having a depth of $41 / 2$ in. in ordinarily good garden soil. The bulbs should be planted thickly so that they almost touch. They should be set at such a depth that the tops protrude slightly above the surface of the soil when the potting is done. Provide drainage by placing a piece of broken flower-pot over the hole in the bottom of the pot. The surface of the oil in the pan should be half an inch below the rim of the pan, so as to allow the bulbs to be watered efficiently.

As soon as planted the pan should be well watered and set away in the coolest part of the cellar, not near the furnace or any fire heat. If the cellar is light, the bulbs should be covered with boxes or old bagging, or anything that is convenient to keep them dark.

If the soil gets dry it must be watered and a natural condition of moisture maintained. Bulbs that have been potted early in September should be thoroughly rooted by November 10 . They may then be brought into the living-room and will bloom in seventeen to twenty-one days. After bringing the pans into the living-room they should be freely watered. By taking a pan or more of bulbs from the cellar every week or ten days, a succession of flowers for the table can be had through the Winter and Spring.

Dutch Hyacinths, Tulips and Single and Double Narcissi can be treated in the same manner, except that the bulbs should not be brought out of the cellar before February 8 to 10 .

Polyanthus and Paper-White Narcissi and Chinese Sacred Narcissi are not hardy. Do not allow the frost to reach them, or failure will result.

Culture in Water with Pebbles. Chinese Sacred Narcissus, Paper-White and all the Polyanthus or bunch-flowered Narcissi can also be grown in water, with pebbles, in shallow dishes and bowls or in our Prepared Fiber.

BODDINGTON'S FRENCH PAPER-WHITE NARCISSI $\quad$ XX Doz. 100 BODDINGTON'S FRENCH PAPER-WHITE NARCISSI. X $\mathrm{X} \ldots \ldots .60 \quad \$ .50$

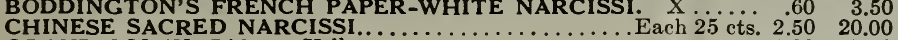
GRAND SOLEIL D'OR. Yellow.

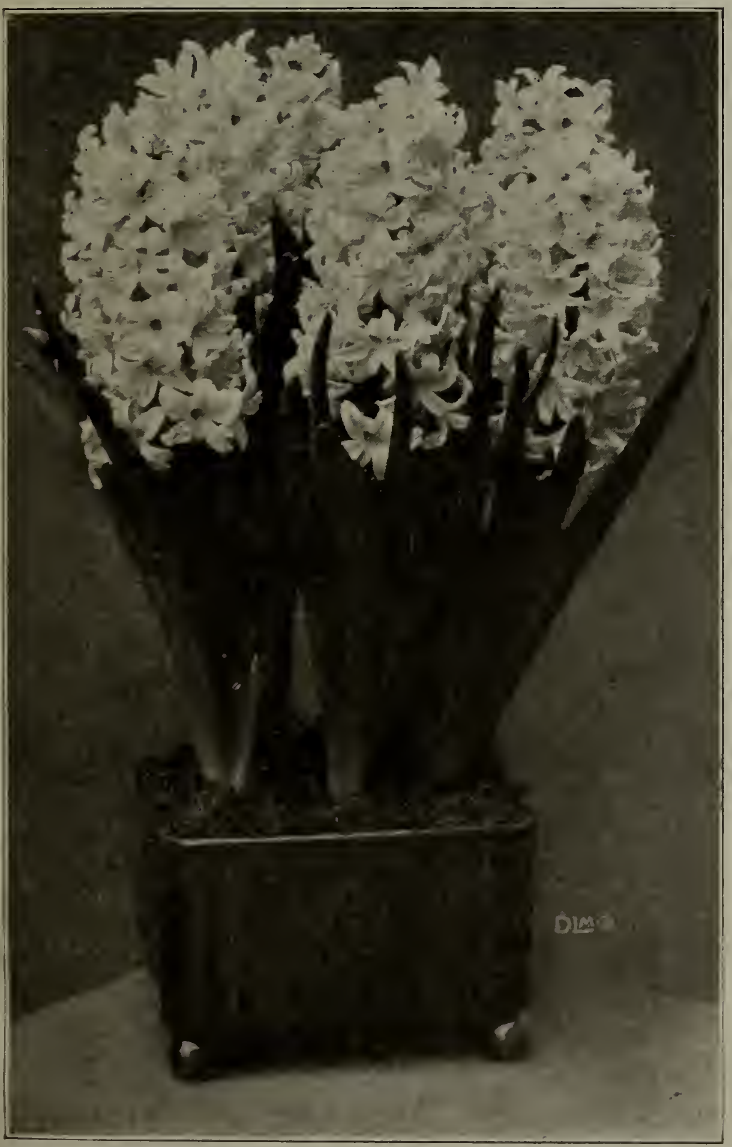

GLASS BOWLS FOR 3 BULBS OF NARCISSI PAPER-WHITE......Each $25 \mathrm{cts}$ GLASS BOWLS FOR 6 BULBS OF NARCISSI PAPER-WHITE..... Each $35 \mathrm{cts}$.

\section{House Culture of Bulbs in Fiber}

How to Grow Bulbs inVases, Bowls, Jardinieres, etc., without drainage

Our specially prepared Fiber is fertilized and mixed with pulverized charcoal and crushed oyster shells. This combination furnishes all the plant-food elements required by bulbs, and only needs to be moistened with water before use. Any of the Spring-flowering bulbs may be grown in our prepared Fiber, in non-porous bowls without drainage.

CULTURAL DIRECTIONS. - When growing bulbs in vases without drainage it is first necessary to water the Fiber, then rub it through the hands until it is free from lumps. If the mixing is properly done the Fiber will increase in bulk, and if taken in the hand and squeezed, little or no water should drop out. When potting, put the large pieces of charcoal (which we send with the Fiber) in the bottom of the vase to absorb the impurities and keep the mixture sweet, then put in 1 to 3 inches of the Fiber, according to the depth of the bowl. After placing the bulbs in position so that their tips reach to within half an inch of the rim, the spaces between and around the bulbs should be filled with the moistened Fiber. It is not necessary or desirable to press it tightly, as the roots do not grow freely if it is pressed too firmly. Small bulbs such as Freesias, ('rocuses, should le planted fairly close together in order to produce the best effect. After planting, the bowls should be kept in a cool, airy cellar or room (not a confined closet) for about ten to twelve weeks, so that they may develop good root-growth, which is very essential in order to get good results. The bowls should be examined once a week, and a little water given when necessary, as the Fiber must not be allowed to get dry or the flower buds become "blind," The surface should always look moist, but if too much water has been given, the bowl may be held carefully on its side so that the surplus water can drain away. As the growth increases more water will be required and as much light as possible to insure sturdy foliage. A succession of bloom may be had during the Winter by taking into the house a few dishes at intervals of about two weeks.

\section{Hyacinth Bulbs (1st size, named)}

Suitable for growing in Fiber, your selection of color or variety. $25 \mathrm{cts}$ each, $\$ 2.00$ per doz., $\$ 15.00$ per 100 .

\section{Boddington's Prepared Fiber}

\section{(FERTILIZED)}

Single Dutch Hyacinth La Grandesse, growing in Boddington's Prepared Fertilized Ftber

Half-peck 30 cts., peck 50 cts., half-bushel $8.5 \mathrm{cts}$., bushel $\$ 1.50$. We do not pay transportation on Prepared Fiber. If wanted by parcel post, add for postage at your zone rate from New York, on $1 / 2$ peck, postage for $4 \mathrm{lbs}$, peck, postage for 7 lbs., bushel, postage for 27 lbs. 


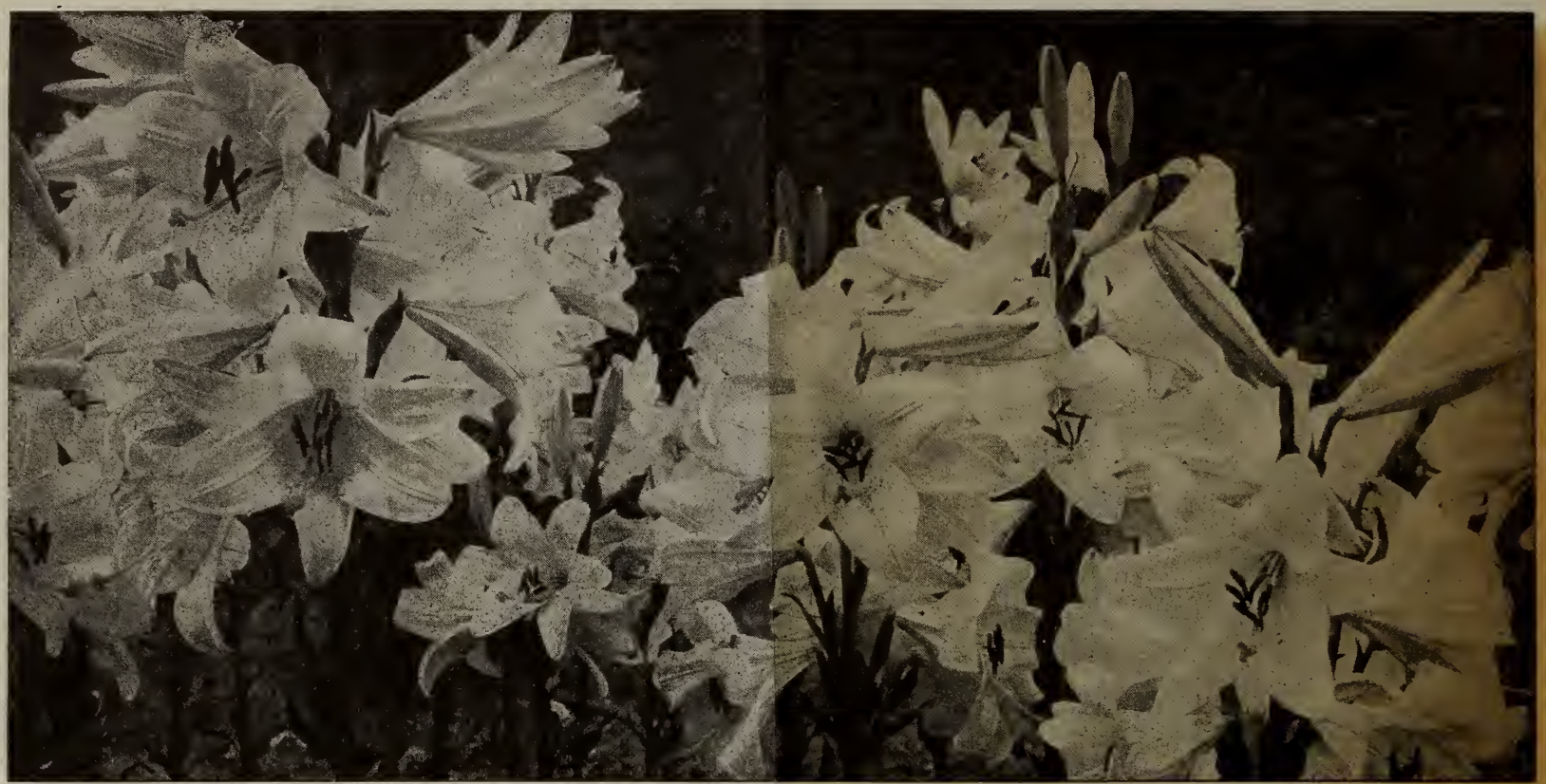

Lilium candidum (Madonna, St. Joseph, or Annunciation Lily). Perfectly hardy; flowers outdoors in June

\section{Lilies for Growing and Forcing Under Glass in the Greenhouse or Conservatory or Outdoor Planting}

Pot Culture.-Lily bulbs should be potted immediately after they are received. The soil should be rich, and well drained by placing three or four pieces of broken flower-pot over the hole in the pot. In planting, place each bulb so that its top shall be half an inch below the surface of the soil, and an inch below the rim of the pot, so as to allow the pot to be watered efficiently.

After potting give a thorough watering and set outside in a coldframe or bury the pots outdoors. After they have stood about two months, they may be brought into a greenhouse having a night temperature of 58 to 60 degrees.

After the plants show buds, slightly higher temperature may be used to advantage.

\section{September-October LILIUM CANDIDUM (Madonna, St. Joseph, Delivery LILIUM CANDIDUM or Annunciation Lily)}

This is the old-fashioned garden Lily. Can be forced for Easter and is perfectly hardy, blooming in the open ground in June. The many snow-white flowers, borne on a stem 3 to 4 feet high, make this Lily most effective. This variety should be planted in the early Fall, as it makes an Autumn growth. Bulbs grown for us near Paris, France; the large-flowering, thick-petaled variety. 20 cts. each, $\$ 2.00$ per doz., $\$ 15.00$ per 100 . Monster bulbs, 25 cts. each, $\$ 2.75$ per doz., $\$ 20.00$ per 100 .

\section{EASTER LILIES}

\section{Lilium longiflorum formosum}

The earliest type of the well-known Easter Lily. Ready for delivery in September. Easy to force in the greenhouse, and hardy outdoors with slight protection. Flowers in the open ground in June.

7- to 9-inch bulbs (300 in a case)

9 - to 10 -inch bulbs (200 in a case) $\ldots . . \$ 0.40 \quad \$ 4.00 \quad \$ 30.00$

$\begin{array}{rrrr}10 \text { - to } 12 \text {-inch bulbs (150 in a case) } \ldots . . . & 1.10 & 12.00 & 90.00\end{array}$

11- to 13 -inch bulbs (100 in a case) $\ldots . .2 .00 \quad 17.50 \quad 130.00$

\section{Lilium longiflorum giganteum}

This dark-stemmed variety flowers later than Formosum, but is of larger size and of greater substance. November delivery. Hardy outdoors with slight protection. Flowers in the open ground in June.

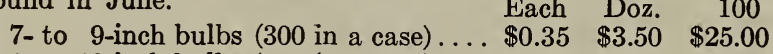

8 - to 10 -inch bulbs (225 in a case) $\ldots . . . \quad r 65 \quad 6.50 \quad 50.00$

$\begin{array}{lllll}9 \text { - to } 10 \text {-inch bulbs (200 in a case) . . . } & 1.00 & 10.00 & 80.00\end{array}$

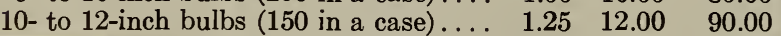

\section{Lilium longiflorum multiflorum}

One of the best Japanese Easter Lilies, not so early as the Formosum type but a month earlier than Giganteum.

$\begin{array}{rrrrr} & \text { Each } & \text { Doz. } & 100 \\ 7 \text { - to } & \text { 9-inch bulbs (300 in a case) } \ldots & \$ 0.35 & \$ 3.50 & \$ 25.00 \\ 9 \text { - to } 10 \text {-inch bulbs (200 in a case) } \ldots & 1.00 & 10.00 & 80.00 \\ 10 \text { - to } 12 \text {-inch bulbs (150 in a case) } \ldots & \ldots & 1.10 & 12.00 & 95.00\end{array}$

\section{Lilium Harrisii}

Ready for delivery in August. Hardy with protection.

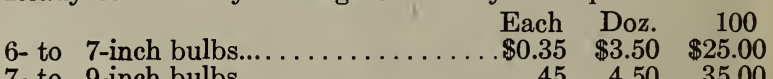

7- to 9-inch bulbs...

$\begin{array}{ll}.45 & 4.50\end{array}$

35.00

\section{Lilium longiflorum (Azores Grown)}

Azores grown longiflorums are remarkably free from disease and bloom as early as Formosum.

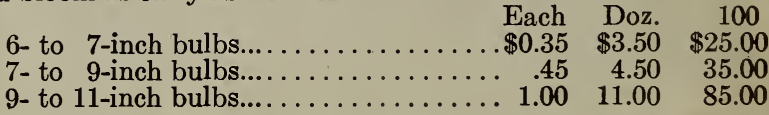


ARTHUR T. BODDINGTON Co., Inc. SEEDSIMEN

128 CHAMBERS STREET

NEW YORK N. Y. 
.

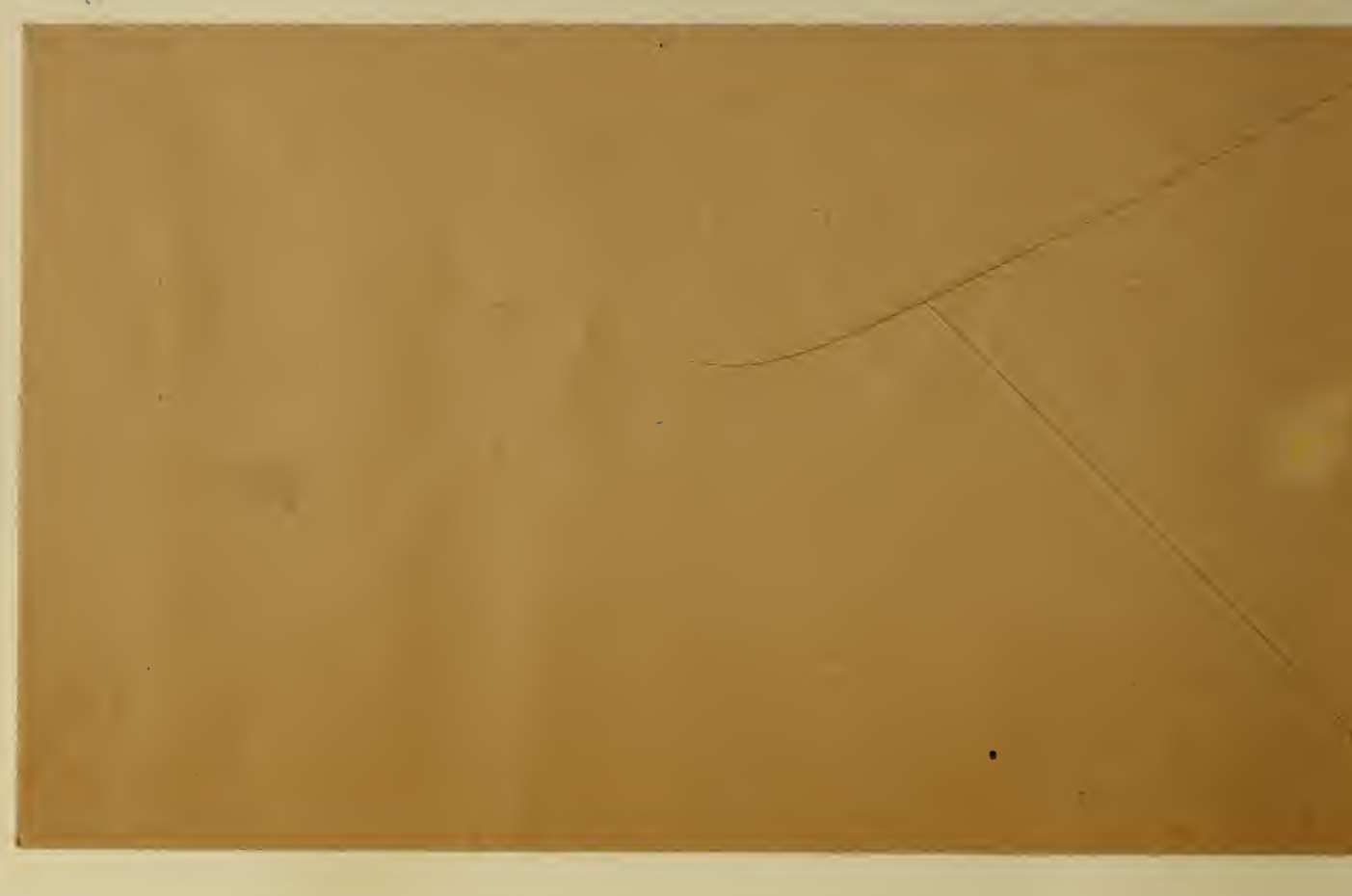




\section{HARDY LILIES}

\section{For Outdoor Planting, or Growing in Pots for Summer Flowering}

Special Notice.-Japanese and some of the European Lilies seldom arrive in New York until about November 15 . As the ground is likely to be frozen in many localities about this date, the ground where the bulbs are to be planted should be protected with a covering of manure, old bagging, or any other material that may be handy, to keep the frost out of the ground until the bulbs are received. Tarieties arriving after December 1 we will deliver in the early spring, unless we are notified to the contrary. For pot culture of Lilies, ee page 2 .

Outdoor Culture of Lilies.-A deep, moist, rich loam is necesary for Lilies. They all thrive best in soil containing an abundance of decomposing vegetable matter, and a partially shaded location is desirable, such as an open space in the shrubbery or perennial border. If manure is used in the preparation of the bed, be sure that it is well rotted and that it does not come in direct contact with the bulbs; n fact, we recommend placing an inch of sand immediately beneath each bulb to provide drainage. Due to the varying sizes of bulbs of different varieties, it is not possible to make any hard-and-fast rule as to the depth that Lily bulbs should be planted. It is a safe practice, however, to cover the bulbs twice their own depth.

\section{Lilium auratum \\ Golden-rayed Lily of Japan}

Monstrous white flowers, thickly studded with crimson spots, ch petal marked with a wide gold band. Each Doz 100

8 to 9 -inch bulbs.................... \$0.35 $\$ 3.50 \$ 25.00$

9 to 11 -inch bulbs........................ $45 \quad 4.50 \quad 35.00$

11 to 13 -inch bulbs.......................... $65 \quad 6.50 \quad 50.00$

Monsters........................ .80 $8.00 \quad 65.00$

\section{Lilium speciosum magnificum \\ (Oriental Orchids)}

Frosted white, spotted, clouded and bordered with deep pinkish crimson. A superior variety of the Speciosum to Roseum, Rubrum or Melpomene. For the border, among hardy plants or naturalized mong Rhododendrons, this is an equal favorite with the Lilium auratum. Splendid for pot culture. Blooms outside during August.

8 to 9 -inch bulbs .................... \$0.35 \$3.50 \$25.00

9 to 11 -inch bulbs ................... $45 \quad 4.50 \quad 35.00$

11 to 13 -inch bulbs............................. $65 \quad 6.50 \quad 50.00$

13 to 15 -inch bulbs.................. $80 \quad 8.00 \quad 65.00$

\section{Lilium speciosum album}

The white Speciosum, which is usually grown with Magnificum and Lilium auratum. It flowers outside in the border or among Rhododendrons at the same time as Auratum and Magnificum, and is one of the most extensively cultivated varieties. Each Doz. 100

8 to 9 -inch bulbs................. \$0.35 $\$ 3.50 \quad \$ 25.00$

9 to 11 -inch bulbs...................... $60 \quad 6.00 \quad 40.00$

11 to 12 -inch bulbs

\section{Lilium Henryi}

(The Yellow Speciosum)

A new and very beautiful hardy Lily from Northern China. The plants are of vigorous growth, frequently attaining the height of 6 feet. This Lily is noted for its graceful habit and is an unusually excellent bloomer. It is thoroughly hardy, and, when well established, will increase rapidly. Color rich golden yellow, lightly spotted with brown, and in shape quite resembles the Speciosum types.

Choice bulbs, 75 cts. each, $\$ 7.50$ per doz., $\$ 60.00$ per 100 .

\section{Lilium regale (Myriophyllum)}

\section{(The Regal Lily)}

Perhaps the most satisfactory of the hardy Lilies. White, slightly suffused pink, canary yellow at the center. Absolutely hardy and excellent for Easter forcing. In view of possible complete plant exclusion in 1925. We suggest that persons having greenhouses would do well to experiment with this Lily for Easter forcing. It blooms out of doors in early July.

$\$ 1.25$ each, $\$ 12.00$ per doz., $\$ 90.00$ per 100 .

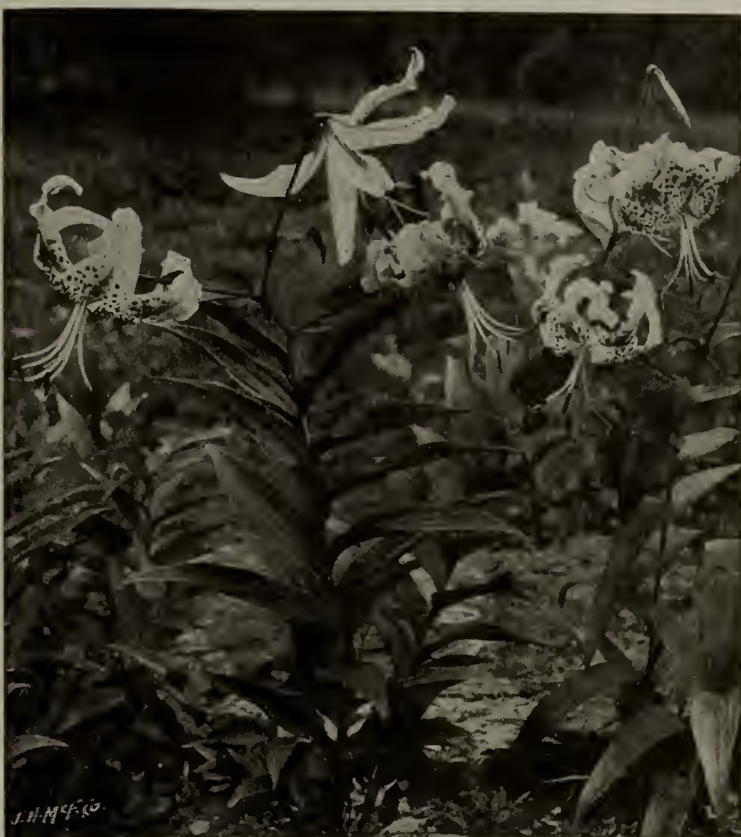

Lilium speciosum magnificum

\section{OTHER HARDY LILIES}

\section{Suitable for Garden Culture}

Batemanii. A Japanese variety, growing 3 feet Each Doz. 100 high, with six to eight apricot-colored flowers on a stem. Blooms in July and

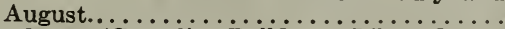
$\$ 0.40 \$ 4.00 \quad \$ 30.00$ Canadense (Canadian Bellilower Lily). One of
the most beautiful native Lilies; flowers bright yellow, with spots of red. Blooms in July and August.

$.30 \quad 3.00$

20.00

Davuricum. Of easy culture, grows 2 to 3 feet high, and blooms in umbels of three to five upright scarlet flowers, dotted black

Davuricum, Yellow. Similar to the above except in color, which is a pure yellow... .

Elegans, Leonard Joerg. Rich apricot,

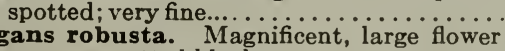

Elegans robusta. Magnificent, large flower
orange, spotted black................

Elegans, Mixed. A mixture of apricot and orange sorts...

Hansonii. Attains a height of 3 to 4 feet. Flowers reddish orange, eight to twelve in a cluster; petals thick and durable..

Pardalinum (Leopard Lily). Scarlet and yellow flowers spotted rich brown..

Superbum. In deep, rich soil this Lily often grows 8 feet high, with twenty to thirty flowers. It is of the easiest 'culture, and may be grown as a wild flower in any swampy or rough part of a place where the grass is not mown. Extra selected bulbs.

Tenuifolium. Grows 20 inches high, with finely cut foliage, slender stems and beautifully shaded coral-red flowers. Blooms very early.

Tigrinum splendens. The finest type of the quaint and much-loved Tiger Lily. Large, selected bulbs.

$\begin{array}{lll}30 & 3.00 \quad 20.00\end{array}$

$\begin{array}{lll}30 & 3.00 & 20.00\end{array}$

$\begin{array}{lll}30 & 3.00 \quad 20.00\end{array}$

$\begin{array}{lll}30 & 3.25 & 20.00\end{array}$

$\begin{array}{lll}.25 & 2.50 \quad 18.00\end{array}$

$.75 \quad 7.50$

60.00

$.30 \quad 3.00$

20.00

Tigrinum splendens, Double. The double form of the above

Wallacei. This Lily is very floriferous, each bulb throwing up four to six flower stems, each one of which is crowned with eight to ten beautiful, upright blossoms, of a delicate, bright apricot color..
$.25 \quad 2.50$

18.00

$\begin{array}{lll}.30 & 3.00 & 20.00\end{array}$

20.00

$\begin{array}{lll}30 & 3.00 & 20.00\end{array}$ 


\section{Arthur T. Boddington Co., Inc., 128 Chambers St., New York City}
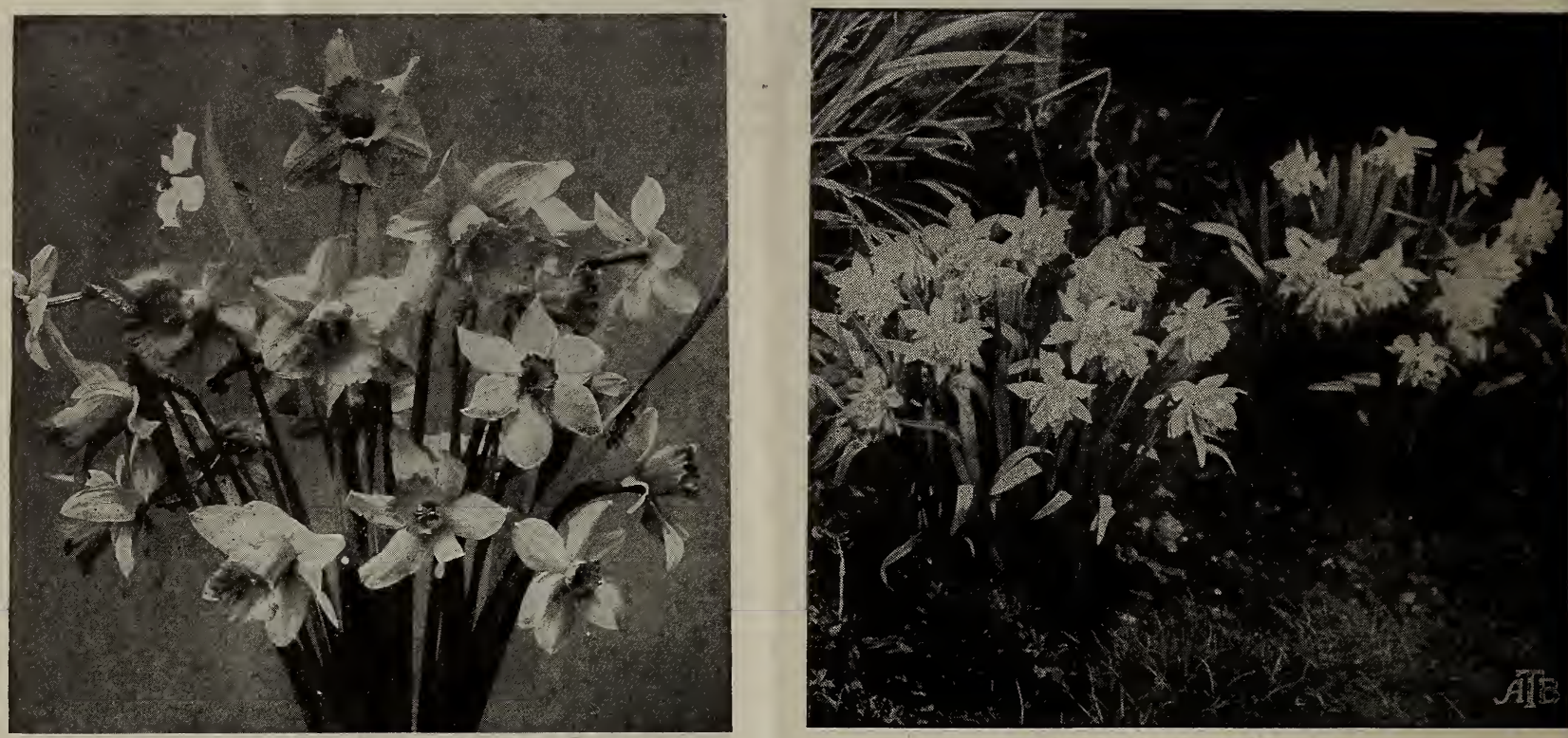

Single Trumpet and Chalice-Cup Narcissus in variety

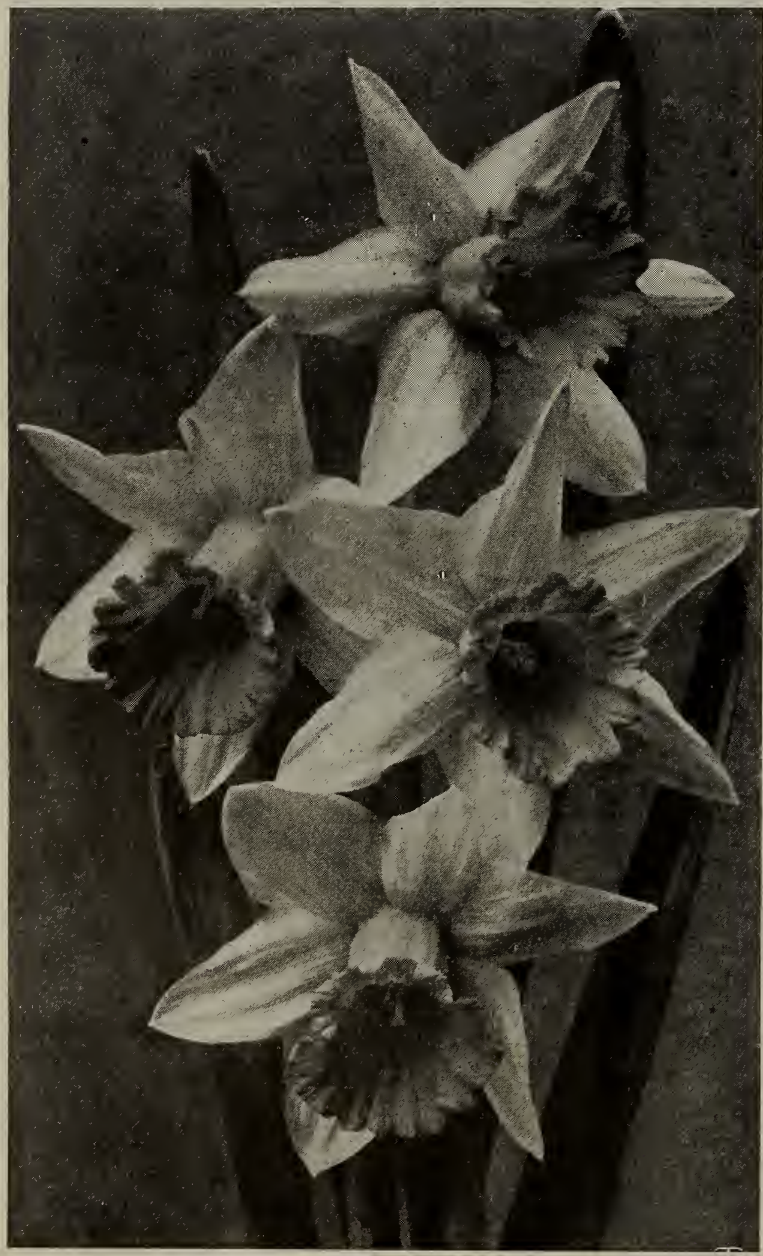

Double Narcissus, Von Sion 


\section{NARCISSI}

GULTURAL DIRECTIONS SAME AS FOR TULIPS

\section{Giant Single Trumpet Narcissi}

Albicans. Perianth white, trumpet primrose, passing to white................\$0.75 \$5.50 $\$ 50.00$ Ard Righ (Irish King). Perianth yellow, trumpet deep yellow; one of the best of the

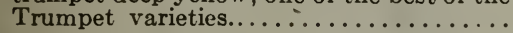
$\begin{array}{lll}.75 & 5.50 \quad 50.00\end{array}$

Emperor. A noble single Narcissus; pure golden yellow, of very large size, with immense trumpet.

First-size round bulbs. X............... .75 $5.50 \quad 50.00$

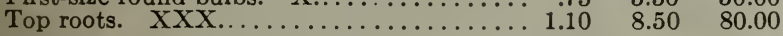

Empress. Pure white perianth, with rich, yellow trumpet; a splendid variety.

First-size round bulbs. $\mathrm{X} \ldots \ldots \ldots \ldots \ldots \ldots . \quad .75$

Top roots. XXX........................ 10

Glory of Leiden. Long, large yellow trumpet perianth primrose-yellow. Top roots.... $1.25 \quad 8.00 \quad 75.00$

Glory of Noordwijk. Perianth sulphur-white, trumpet chrome-yellow, very long and elegantly reflexed at the brim; of good size and substance. Height 14 inches. Top roots.. 1.5010 .00

95.00

Glory of Sassenheim. Larger flower and earlier than Victoria; white perianth, yellow trumpet. Top root bulbs.............

Golden Spur. Deep yellow perianth and trumpet; very large; equally good as a forcer and for the garden.

First-size round bulbs. $\mathrm{X} \ldots \ldots \ldots \ldots \ldots . .75$

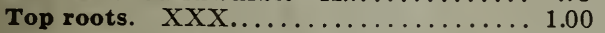

Guernsey-Grown. Can be flowered under

glass by January 1 .............................. glass in December......................

Henry Irving. Magnificent flowers of richest yellow; trumpet beautifully frilled.........
sfieldii. Discarded. Victoria is recom-

Morsfleldii. Discar
mended instead.

King Alfred. Golden yellow perianth and trumpet; of beautiful form with deeply frilled mouth; gigantic flower; strong grower; does not force well. Top roots.....

Madame de Graaff. Perianth pure white, $\begin{array}{llll}\text { trumpet pale primrose. Top roots........ } 1.10 & 8.50 \quad 80.00\end{array}$

Madame Plemp. Pure white perianth; golden yellow trumpet. A bold and solid flower.

Top roots............................ pale lemon trumpet, passing into white, elegantly frilled; one of the best growers among white Trumpets, and a free bloomer.

Obvallaris. Perianth and trumpet yellow.....

Olympia. Pale yellow perianth, yellow trumpet; as large as King Alfred. Good forcer. Top roots........... $35 \mathrm{c}$. each 3.50

6.00

8.00

55.00

$.75 \quad 5.50$

50.00

.856 .50

60.00

$.75 \quad 6.00$

55.00

1.008 .00

75.00

.85

$6.50 \quad 60.00$

$\begin{array}{lll}.70 & 5.00 \quad 45.00\end{array}$

25.00

Princeps. Early; sulphur trumpet, white perianth. A popular forcing variety

Double-nose bulbs. X................

Top roots. XXX..................

Silver Spur. Resembles Empress. The earliest Bicolor variety for forcing..........

Sir Watkin. Perianth sulphur, cup yellow, tinted bright orange; large flower.

Double-nose. X..................... 1.00

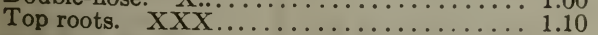

Trumpet Major. (French-grown). Excellent for Christmas forcing; not worth growing for any other purpose.............

Van Waveren's Giant. Primrose perianth, $b_{\text {right yellow trumpet; larger than King }}$ lfred and a better forcer.....35c. each

Victoria. White perianth, yellow trumpet.

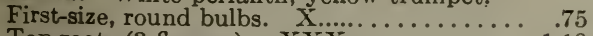

Top roots (3 flowers).

5.50

$6.50 \quad 60.00$

$8.50 \quad 80.00$

7.50

70.00
GIANT SINGLE TRUMPET NARCISSI-Continued $\begin{array}{llll}\text { Von Sion, Single. Fine yellow trumpet..... } \$ 0.75 & \$ 5.50 & \$ 52.00\end{array}$ Trumpets, Mixed. Many varieties........ $.70 \quad 5.00 \quad 48.00$

\section{Double Narcissi, or Daffodils}

Von Sion (True Double Yellow Daffodil). Doz. 100 10uv Top-root bulbs. XXXX.............. \$1.10 $\quad \$ 8.00 \quad \$ 75.00$

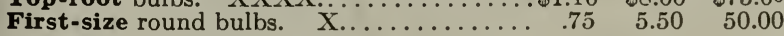

Alba-plena odorata (Gardenia-flowered Daffodil). Double, snow-white flowers; very sweet-scented; late flowering.............

$.50 \quad 4.00 \quad 35.00$

Incomparabilis fl.-pl. (Butter and Eggs). Rich yellow and white; double; good forcer and excellent for the garden.............

Orange Phœnix (Bacon and Eggs). Beautiful white and orange Narcissi...........

Sulphur, or Silver Phonix (Codlins and Cream). Creamy white, pale sulphur center

Boddington's "Quality" Double Mixture.

Excellent for bedding or naturalizing...... $\quad .75 \quad 5.50 \quad 50.00$

$\begin{array}{lll}.75 & 6.00 & 55.00\end{array}$

$\begin{array}{lll}.75 & 6.00 & 55.00\end{array}$

$\begin{array}{lll}.75 & 6.00 & 55.00\end{array}$

\section{New Narcissi, Poetaz Hybrids}

Hybrids between $N$. poeticus ornatus and $N$. polyanthus varieties

\section{Perfectly Hardy}

Admiration. Sulphur-yellow perianth, sulphur-yellow eye, bordered scarlet. Perhaps the finest of all the Poetaz varieties. Doz. 100 30c. each $\$ 2.00 \$ 15.00$

Alsace. Petals pure white, with yellow eye; when bursting into flower the eye is slightly edged reddish. Broad, large flowers of true Poet form; one of the earliest. Has three

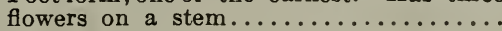

$\begin{array}{lll}.85 & 6.50 & \$ 60.00\end{array}$

Elvira. Pure white, with yellow eye; large flower of remarkably good substance. Longstemmed, and a good keeper; four flowers on a stem. Highly recommended........

$\begin{array}{lll}.75 & 6.00 \quad 55.00\end{array}$

Ideal. Perianth white, with dark orange eye; large truss bearing six or seven flowers; beautiful, striking color.................. Eight or nine flowers on a stem............. golden yellow eye............30 . each 2.0015 .00

Mignonne. White, orange-scarlet cup; four to five flowers on a stem.

1.259 .00

\section{Poet's Narcissi}

Delicately perfumed and charming in form and color. The Poet's Narcissi all have snowy-white perianth and a feathered edge or short crown, usually yellow, edged scarlet, though sometimes entirely scarlet. All are sweet-scented. They are adapted for indoor plants in pots, and also fine for planting among shrubbery or in the grass. A rich, deep soil of a moist character suits then best.

Poeticus (type) (Pheasant's Eye, or Poet's Doz. 100 Narcissus). Mother bulbs.............\$0.60 $\$ 4.50 \quad \$ 40.00$

Poeticus, Cassandra. Strong grower; flowers of fine substance with broad, white perianth cup deeply rimmed dark red.....30c. each $2.00 \quad 15.00$

Poeticus, Horace. Broad snowy white perianth; large cup deeply edged blood-scarlet. Very beautiful...............30c. each $2.00 \quad 15.00$

Poeticus, King Edward VII. Snow-white petals and beautiful shape; cup canary-

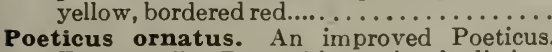
Forces well. Pure white perianth, distinct red crow口. Top roots. XXX ...........70 $5.00 \quad 45.00$ 


\section{Arthur T. Boddington Co., Inc., 128 Chambers St., New York City}

\section{NARGISSI AND DAFFODILS-Continued}

\section{Chalice-Cup, or Star Narcissi}

Barrii, Conspicuus. Large soft yellow peri- Doz. 1001000 anth; short cup, edged orange-scarlet.... $\$ 0.70 \quad \$ 5.00 \$ 45.00$ Incomparabilis, Gloria Mundi. Clear yellow perianth orange-scarlet cup........ Incomparabilis, Lucifer. White perianth, Incomparabilis, Figaro. Perianth primrose-sulphur; cup bordered orange-red....

Leedsii, Mrs. Langtry. Broad white perianth and large white cup, edged bright yellow

Leedsii, Queen of England. Beautiful large flowers, with fine, fringed, citron-

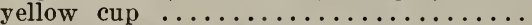

Cup Narcissi, Mixed. Many varieties... $.50 \quad 4.00 \quad 36.00$

\section{JONQUILS $\underset{\substack{\text { Narcissus } \\ \text { Jonuuilla }}}{\substack{\text { J } \\ \text { J }}}$}

Double Sweet-scented. Fine, deep yellow. $\$ 0.60 \quad \begin{array}{lll}\$ 4.50 & \$ 40.00 & 100\end{array}$ Single Sweet-scented. Deep yellow .... $\quad .50 \quad 3.50 \quad 30.00$ Giant Campernelle. Large; yellow..... $.50 \quad 3.50 \quad 30.00$ Rugulosus. Very fragrant, large Jonquils.

Double-nosed bulbs. XXX ................ $60 \quad 4.50 \quad 40.00$

\section{Boddington's "Quality" Paper-White Narcissi}

Most useful for early forcing is the well-known Paper-IVhite Narcissus Grandiflora. The flowers are pure white, chaste and beautiful, borne on long stems, sometimes as many as fifteen to a stem. This variety is not hardy and can only be grown under glass, or in a sunny window. For cultural directions, see page 1 . Paper-White, Grandiflora.

XXX, 15 centimeters and up.

XX, 14 centimeters and up.

Doz. $100 \quad 1000$ $\$ 0.85 \$ 5.00 \$ 45.00$

$\begin{array}{lll}.75 & 4.50 & 40.00\end{array}$

\section{Polyanthus, or Bunch-Flowered Narcissi}

Polyanthus Narcissi are not hardy, and must not be subjected to frost at any time. For culture, see page 1.

Chinese Sacred. White, yellow cup. Top Doz. 1001000 roots................25 cts. each. $\$ 2.50 \$ 20.00$

$\begin{array}{lllll}\text { Double Roman. White flowers, yellow cup } & 50 & 3.50 & 30.00\end{array}$ GRAND SOLEIL D'OR. The "Yellow

Paper-White."

Erench-grown. Earlier than Guernsey-

grown ......................

Guernsey-grown. Not so early, but can be flowered for Christmas; superior as

to color ................... $1.00 \quad 7.50 \quad 70.00$

$\begin{array}{lllll}\text { Grand Monarque. White flower, yellow cup } & .60 & 3.50 & 30.00\end{array}$ Grand Primo. Large, white flower, citron

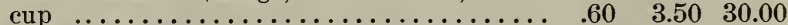
Staten General. Large, white flower... $\quad .60 \quad 3.50 \quad 30.00$ The above can be grown in bowls of water and pebbles or in our prepared fiber. Pebbles $15 \mathrm{cts}$. per qt.

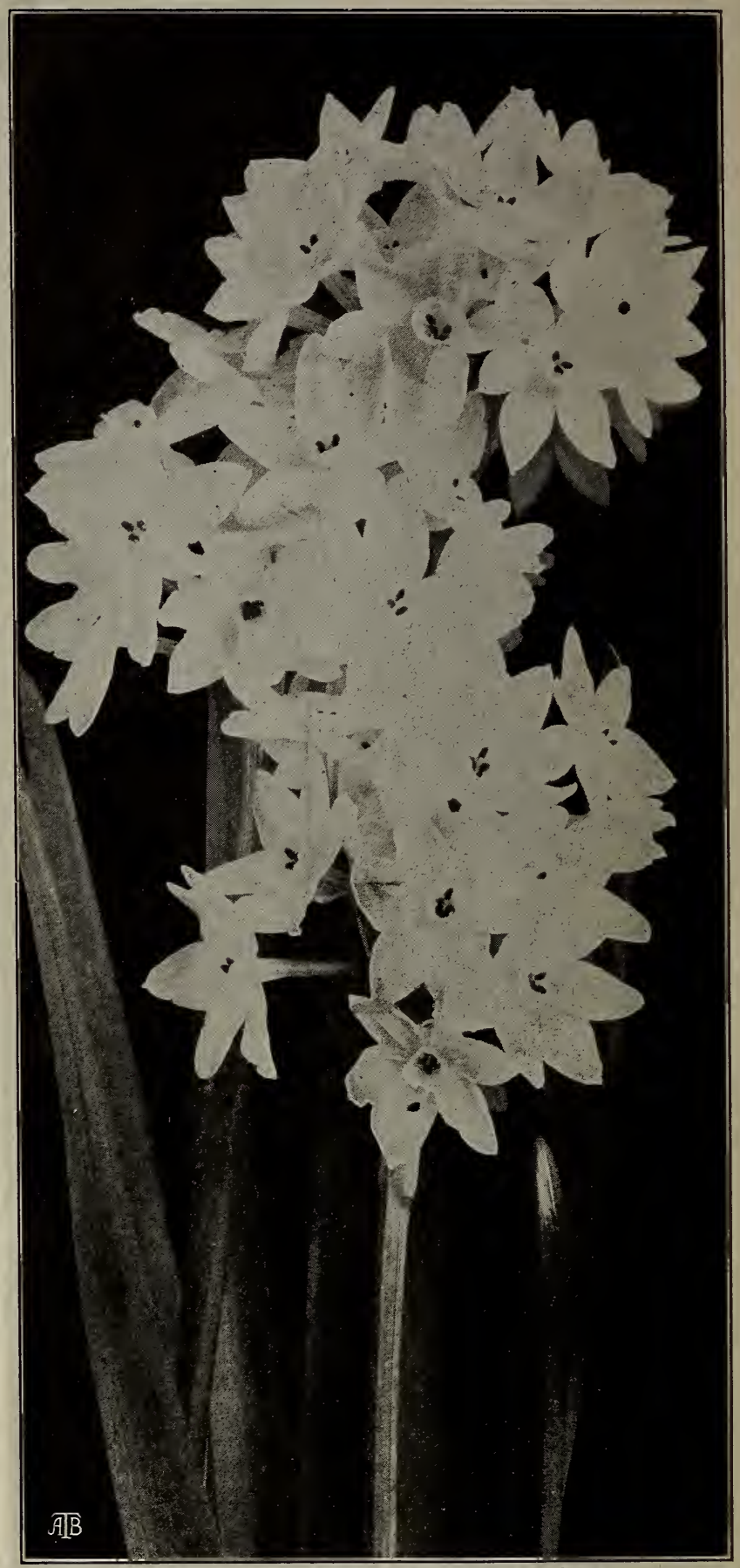

Boddington's Quality Paper-White Narcissus

\section{Boddington's Dutch Roman, or Miniature Hyacinths}

These are small bulbs, or Miniature Dutch Hyacinths, and are now very largely used for growing in pans or pots. They are also used extensively for bedding purposes, as they produce large spikes of flowers. We can specially recommend our "Quality" Dutch used extensively for bedane never grown them, and therefore do not know their value. They consist of mamed sorts, similar to regular first-size Dutch Hyacinths, of the finest grade and true to name. 12 to 15 centimeters in circumference.

Czar Peter. Light porcelain-blue.

Gigantea. Daybreak-pink.

Grand Maitre. Deep porcelain-blue.

Grandeur a Merveille. Blush-white.
La Grandesse. Pure white.

L'Innocence. White; one of the best.
Moreno. Waxy pink.

Queen of the Blues. Sky-blue ; fine.

Schotel. Pale blue.

Yellow Hammer. Finest golden yellow. 


\section{Boddington's Extra-Selected Dutch Hyacinths}

\section{CULTURAL DIRECTIONS}

HYACINTHS IN POTS. It is important in the pot culture of Hyacinths to have rich, light soil. If the bulbs are to be potted singly, pots 5 inches in diameter are the proper size. Cover the hole in the pot with a piece of broken pot, and over this place a layer of moss, which will keep the soil from clogging the drainage thus provided. Break off any offsets which appear at the base of the bulbs, and, in potting, place each bulb so that its top shall be half an inch below the surface of the soil and an inch below the rim of the pot. The soil should be of usual natural moisture, and should be pressed moderately firm. The filled pots may be placed in a coldframe where there is protection from frost, or in the coolest part of the cellar, and well watered. An excellent plan is to place them on a bed of moist, sifted coal-ashes, covering the pots to a depth of 6 inches with the same material. When well rooted, which will be in about ten weeks, the bulbs may be brought indoors and forced. For the first two or three weeks they should be kept in a temperature not exceeding 50 degrees. Success in forcing depends much on their having strong roots before being brought to the light. The top grows rapidly, and unless the roots are started much in advance they are unable to nourish the plant, and failure results.

Hyacinths for early use may be potted in September or October; when desired for late use, it is better to pot them in October and keep them in a coldframe or cellar just above freezing point until it is desired to force them into bloom. To obtain dwarf foliage and fine flower-spikes, Hyacinths, when being forced. should have plenty of fresh air, and should have as much light as possible. The blooms last much longer if shaded from the sun after they show color.

\section{PRICES OF DUTCH HYACINTH BULBS}

Boddington's “Top-Root" Named Dutch Hyacinths, purchaser's selection of varieties..\$0.30 $\$ 3.00$ \$20.00

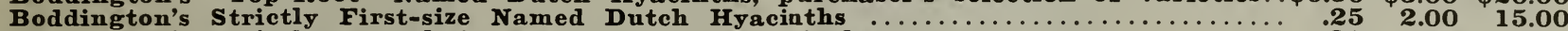

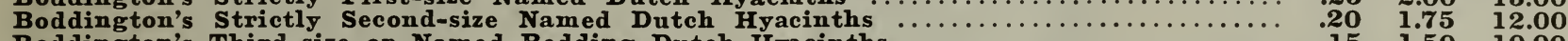

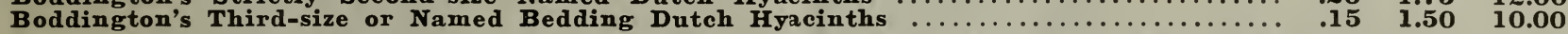

Bedding Hyacinths, Separate Colors, pink, rose, red, white, blush-white, light blue, dark blue, yellow or all colors mixed.

\section{SINGLE WHITE AND TINTED}

Albertina. Pure white; very fine.

ARENTINE ARENDSEN. Early pure white, open petals. British Queen. Very fine, pure white.

Grandeur a Merveille. Finest blush-white; immense truss. Grande Blanche. Blush-white ; very large bells; excellent truss. General Vetter. A beautiful white variety.

L'INNOCENCE. Pure white ; extra large.

LA GRANDESSE. Finest pure white; large bells.

Mme. Van der Hoop. Pure white; large truss; dwarf ; late. QUEEN OF ENGLAND. Pure white; large bells; early.

\section{SINGLE RED, ROSE AND PINK}

CARDINAL WISEMAN. Bright rose; large flower. ETNA. Brilliant pink; very large bells; late.

GENERAL DEWET. Light pink; also called the pink Grand Maitre.

General Pelissier. Deep crimson; fine truss; early.

GERTRUDE. Rosy pink ; compact truss; best of its color. GIGANTEA. Blush-rose; large; close truss; one of the best. Garibaldi. Glossy crimson; good truss; very early.

Jacques. Delicate pink; very large spike.

Kohinoor. Bright pink; extra-large truss; one of the largest flowers; semi-double.

LADY DERBY. Most beautiful light pink.

LA VICTOIRE. Immense, brilliant red truss of the most perfect form.

Moreno. Waxy pink; large bells and truss.

Ornement Rose. Light rose; superb flower.

QUEEN OF THE PINKS. Lively pink. This is a sport of the well-known King of the Blues.

Rosea Maxima. Lovely pink; grand bloom.

Roi des Belges. Fine, deep red.

VICTOR EMANUEL. Brilliant red; large truss; early.

\section{SINGLE BLUE, PURPLE AND VIOLET}

BISMARCK. Light sky-blue; blooms very easily at Christmas. The earliest blue Hyacinth.

Czar Peter. Large ; porcelain-blue, lighter center; grand truss.

ELECTRA. Porcelain-blue ; enormous flower.

ENCHANTRESS. Very delicate porcelain-blue.

Grand Lilas. Light porcelain-blue; good variety for early forcing.

Grand Maitre. Deep porcelain-blue; large truss.

Johan. Pale blue-gray ; large bells; splendid, compact spike.

King of the Blues. Rich, dark blue; splendid, well-finished truss.

L'Esperance. Dark purple; splendid bedding variety.

Lord Balfour. Deep violet; very early ; enormous truss. The best of the violets.

Marie. Deep blue; large truss.

MENELIK. The darkest of all the blues; immense truss.

\section{SINGLE BLUE, PURPLE AND VIOLET-Continued}

PERLE BRILIIANT. Light, brilliant blue; an excellent all-round variety.

Pieneman. Brilliant light blue; large, broad truss.

Potgieter. Light blue; excellent variety.

Queen of the Blues. Porcelain-sky-blue; large bells and fine spike.

Regulus. Porcelain-blue ; large bells.

SCHOTEL. Pale blue; good forcer.

Sir William Mansfield. Violet; splendid truss; one of the best in its color; splendid bedder.

\section{SINGLE YELLOW AND ORANGE}

\section{CITY OF HAARLEM. Golden yellow; extra-large flower ;} one of the best of the yellows.

Ida. Pure, light yellow; large truss ; early

King of the Yellows. Pure, deep yellow; large truss.

MacMahon. Nankeen-yellow; fine.

MARCHIO NESS OF LORNE. Orange-yellow; very fine spike.

Yellow Hammer. Golden yellow; the finest of its color.

\section{DOUBLE WHITE AND TINTED}

Bouquet Royal. Pure white, yellow center; good truss.

GRAND VAINQUEUR. Pure white; early.

Isabella. Blush-white; large bells; very fine.

La Grandesse. The double form of this well-known variety.

La Tour d'Auvergne. Pure white; good bells; large truss; extra.

\section{DOUBLE RED, ROSE AND PINK}

CHESTNUT FLOWER. Rose; large truss; very beautiful. Le Grand Concurrent. Beautiful pale rose; large bells and truss ; extra.

Lord Wellington. Delicate rosy blush; large bells and truss; one of the best.

PRESIDENT ROOSEVELT. Fine, dark pink; a very fine variety ; large bells; early.

Prince of Orange. Rose-red; semi-double ; a beautiful variety.

\section{DOUBLE BLUE AND PURPLE}

Bloksberg. Pale porcelain-blue.

Garrick. Bright blue; very large bells.

GENERAL KOHLER. Bright blue ; extra fine ; an excellent variety.

Van Speyk. Light blue; large bells and truss.

\section{DOUBLE YELLOW}

Goethe. Light yellow; large bells; fine spike.

Jaune Supreme. Deep yellow, salmon tinted.

SIR ROLAND HILL. Pure, dark yellow; large bells; very fine. 


\section{BODDINGTON'S GIANT DARWIN TULIPS}

Darwins form a distinct class of Tulips; they can be easily distinguished from other late Tulips by the cup-shape of the flowers, the robust growth of almost every one of them, and the white, blue or black, but never yellow, markings inside at the base of the flowers. If the base is yellow, it is not a Darwin. Another notable characteristic is that the flowers are just as beautiful, and in some instances, even more beautiful inside the cup than they are outside, which is never so with any other Tulips. With their long stems and their bright colors ranging from white through all the shades of pink and purple to the most fiery scarlet, they are exquisite as cut flowers, and for garden decoration. There are no yellow Darwins. Those that are sold as yellow are either Cottage Tulips or Breeders, and can be found under those heads in our list.

Planted in the herbaceous border, they make a great show in late May and June. Flowers are large and borne upon tall, erect stems. To secure the best effects, plant five to twenty bulbs in a group.

Outdoor Culture.-The bulbs should be planted about 5 inches deep and not less than 5 inches apart. A position sheltered from strong winds should be selected if possible. The best time to plant the bulbs is from October 15 to November 15, though they may be planted later than this, provided the place selected has been protected with a mulching of manure to prevent frost entering the ground. This mulching should not be renewed after the bulbs have been planted, as it tempts mice and moles to make the flower-bed their winter quarters, during which time they devour the bulbs. For the culture of Darwin Tulips in pots and pans. see Early Tulips.

Those marked with a star (*) are especially recommended for forcing

ANTON ROOZEN.* Large-flowering; rosy pink. Height 26 in. 80 cts. per doz., $\$ 6$ per 100 , $\$ 55$ per 1,000 .

ARIADNE. Bright rosy crimson, shaded scarlet; large flower of great substance. Height 28 in. 80 cts. per doz., $\$ 6$ per $100, \$ 55$ per 1,000 .

BARONNE DE LA TONNAYE.* large, well formed. Stems are very of the best Darwins. Height 26 in. per $100, \$ 40$ per 1,000 .

BARTIGON.* Fiery red. Height 26 in. \$1.25 per doz., $\$ 8.50$ per $100, \$ 80$ per 1,000 .

BLEU AIMABLE.* Bright violet-purple, shaded steel-blue inside dark violet-purple with a blue base; very large. Height 26 in. $\$ 3.50$ per doz., $\$ 25$ per 100 .

BLEU CELESTE.* Light blue, very distinct. Height 30 in. $\$ 4$ per doz., $\$ 30$ per 100.

CENTENAIRE.* Rich violet-rose, with a large, blue center ; immense flower of perfect form. Height 32 in. $\$ 1.30$ per doz., $\$ 9.50$ per $100, \$ 90$ per 1,000 .

CITY OF HAARLEM.* The largest of the scarlet Darwins. Brilliant scarlet, with pure white center. Height 32 in. $\$ 4$ per doz., $\$ 30$ per 100.

CLARA BUTT. Beautiful, soft rosy pink. Perhaps the best Darwin of this color. Height 24 in. 65 cts. per doz., $\$ 4.50$ per $100, \$ 40$ per 1,000 .

CREPUSCULE.* Soft rosy lilac, flushed white; a large flower. Height 28 in. $\$ 1$ per doz., $\$ 7$ per $100, \$ 65$ per 1,000 .

DAL ONGARO. Pale lavender-violet; large flower. Height 24 in. $\$ 1.60$ per doz., $\$ 12$ per $100, \$ 100$ per 1,000 .

DREAM. Soft Lilac. Height 27 in. 80 cts. per doz., $\$ 6$ per 100, $\$ 55$ per 1,000 .

EDMEE* (Beauty). A vivid shade of cherry-rose, edged soft old rose. Height 25 in. 75 cts. per doz., $\$ 5.50$ per 100 , $\$ 50$ per 1,000 .

ELECTRA. Soft lilac; a splendid variety. Height 28 in. 70 cts. per doz., $\$ 5.50$ per $100, \$ 50$ per 1,000 .

ERGUSTE.* Soft violet, with a slight silvery flush; white base; inside dark violet. Height 26 in. 80 cts. per doz., $\$ 6$ per $100, \$ 55$ per 1,000 .

EUTERPE. Brilliant, clear lilac. Height 26 in. 85 cts. per doz., $\$ 6.50$ per 100 , $\$ 60$ per 1,000 .

EUROPE. * Fiery salmon-scarlet, white center. Height 22 in. 80 cts. per doz., $\$ 6$ per $100, \$ 55$ per 1,000 .

FARNCOMBE SANDERS.* Fiery scarlet; large. Height 25 in. 90 cts. per doz., $\$ 6.50$ per $100, \$ 62$ per 1,000 .

FAUST. Dark violet, almost black; unique. Height 30 in. $\$ 1.60$ per doz., $\$ 12$ per $100, \$ 100$ per 1,000 .

FEU BRILLANT. Brilliant, clear scarlet; large. Height 24 in. 75 cts. per doz., $\$ 5.50$ per $100, \$ 50$ per 1,000 .

FRA ANGELICO. Deep glossy maroon. One of the finest of this color. Height 26 in. 75 cts. per doz., $\$ 5$ per 100, $\$ 45$ per 1,000 .
FRANS HALS.* Large violet blue flower; tall, strong stems. Height 32 in. $\$ 3.25$ per doz., $\$ 25$ per 100 .

GLOW.* Brilliant glowing vermilion, center blue, margined white. Height 23 in. 80 cts. per doz., $\$ 6$ per 100, $\$ 55$ per 1,000 .

GRYPHUS. Brilliant, dark violet purple; center white, marked blue; a very large flower on a tall, strong stem. Height 28 in. $\$ 1.80$ per doz., $\$ 14$ per 100 .

ISIS. Glowing vermilion ; one of the brightest colored Darwins : very fine. Height 26 in. 75 cts. per doz., $\$ 5.50$ per 100 , $\$ 50$ per 1,000 .

KING HAROLD.* (Mahony.) Purple-red; unique. Height 24 in. 75 cts. per doz., $\$ 5$ per $100, \$ 45$ per 1,000 .

LA FIANCEE. Lilac rose, fading to light rose at the edge ; very large and handsome. Height 26 in. $\$ 6.50$ per doz., $\$ 50$ per 100.

LA TRISTESSE.* Dull slaty blue, with a white base. Height 26 in. 75 cts. per doz., $\$ 5.50$ per 100 . $\$ 50$ per 1,000 .

LANTERN. Pale silvery lilac, passing to white; inside clear lilac with white base; medium sized flower. Height 20 in. 75 cts. per doz., $\$ 5.50$ per $100, \$ 50$ per 1,000 .

LA TULIPE NOIRE.* The historic black Tulip. $90 \mathrm{cts}$. per doz., $\$ 6.50$ per 100 , $\$ 62$ per 1,000 .

LOVELINESS.* Soft, rosy carmine, exquisite color. Height 21 in. 75 cts. per doz., $\$ 5.50$ per $100, \$ 50$ per 1,000 .

MME. JULIE VINOT.* (Princess Elizabeth.) Vivid rosy pink, with white base. A large sized Darwin of sturdy habit. Height 26 in. $\$ 1.25$ per doz., $\$ 8.50$ per 100 . $\$ 80$ per 1,000 . MME. KRELAGE.* Large flower of purplish rose, with a broad margin of blush pink; on a very tall, strong stem. Height 28 in. 85 cts. per doz., $\$ 6$ per $100, \$ 55$ per 1,000 .

MARCONI. Blue-purple, with maroon shading on opening, changing to ashy purple; white base. Height 27 in. 80 cts. 28 in. $\$ 5$ cts. per doz., $\$ 6$ per $100, \$ 55$ per 1,000 .

MARGARET.* (Gretchen.) Beautiful globular flower; outside blush, inside soft blush-rose. The cup-shaped Hower is borne on a strong stem; medium size. Height $2 \cdot 2$ in. 75 cts. per doz., $\$ 5.50$ per $100, \$ 50$ per 1,000 .

MASSACHUSETTS. Beautiful light rose; most attractive. Height 26 in. 80 cts. per doz., $\$ 6$ per 100 , $\$ 55$ per 1,000 .

MASSENET.* (The Dove.) Soft apple-blossom, flushed white, center white; good-sized flower of very delicate beauty. The latest bloomer of all. Height 24 in. $\$ 5$ per doz., $\$ 35$ per 100.

MAY QUEEN. Beautiful soft rose; one of the finest of its color. Height 26 in. 75 cts. per doz., $\$ 5.50$ per $100, \$ 50$ per 1,000 .

MORALIS. * Glossy violet purple, center shaded white; distinct and handsome. Height 32 in. $\$ 1.30$ per doz., $\$ 9.50$ per 100 , $\$ 90$ per 1,000 .

MRS. GROVER CLEVELAND.* Beautiful delicate fleshcolor; on a tall stem. Height 24 in. 70 cts. per doz., $\$ 5$ per $100, \$ 45$ per 1,000 . 
MRS. POTTER PALMER. (Fashion.) Bright purplish violet; large flower. Height $2 \$$ in. 80 ets. per doz., $\$ 6$ per 100. \$ड̃ per 1,000 .

NAUTICUS.* Dark rose, center clear violet, shaded bronze ; large Hower. Height 30 in. 75 cts. per doz., \$5.50 per 100, $\$ 50$ per 1,000 .

NORA WARE.* Beautiful silvery lilac, shaded white. Height 22 in. 75 cts. per doz., $\$ 5.50$ per 100 , $\$ 50$ per 1.000 .

PAINTED LADY.* Creamy white, flushed light lilac. Very effective when used as a border around a bed of one of the scarlet varieties. Height 27 in. 75 cts. per doz., $\$ 5.50$ per $100, \$ 50$ per 1,000 .

PHILIPPE DE COMMINES.* Velvety dark purple; large Hower on strong stem. Height 24 in. 90 ets. per doz., $\$ 6.50$ per 100 , \$62 per 1,000 .

PRIDE OF HAARLEM.* Old-rose flowers of great size and tine form. Most flowers have more than six petals, which gives them a semi-double form. The best Darwin Tulip of its color. Height $3 \mathrm{ft}$. The most popular of all Darwin Tulips. 80 cts. per doz., $\$ 5.50$ per $100, \$ 50$ per 1,000 .

PRINCE OF THE NETHERLANDS. Hushed salmon-rose; extra-large Hower. Height 30 in. $\$ 1.70$ per doz., $\$ 12$ per $100, \$ 115$ per 1,000 .

PROF. RAUWENHOFF.* Splendid salmon-red. Early forcer, and beautiful bedding variety. Height 28 in. $\$ 1$ per doz., $\$ 7.50$ per 100 , $\$ 66$ per 1,000 .

PSYCHE.* Soft rose ; enormous, long-stemmed flower. This is one of the Darwins which is even more beautiful inside than outside the flower. It is one of the earliest forcers. Height 26 in. 75 ets. per doz., $\$ 5.50$ per 100 , $\$ 50$ per 1,000 .

PURPLE PERFECTION. An extra-fine dark purple. Height 23 in. 85 cts. per doz., $\$ 6.50$ per $100, \$ 60$ per 1,000 .

PYGMALION. Purplish red; large flowers. $\$ 1$ per doz., $\$ 7.50$ per $100, \$ 70$ per 1,000 .

QUEEN OF BRILLIANTS. Large, deep; full rose, shaded scarlet. Height 25 in. $\$ 0$ cts. per doz., $\$ 6$ per $100, \$ 55$ per 1,000 .

REV. EWBANK.* Heliotrope-lilac, flushed silver-gray. Height 22 in. 75 cts. per doz., $\$ 5.50$ per 100 , $\$ 50$ per 1,000 .

REV. HARPER CREWE. Amaranth-red, edged deep mauve; inside brilliant crimson-carmine, with blue base. Height 25 in. $\$ 1$ per doz., $\$ 7$ per $100, \$ 65$ per 1,000 .

RONALD GUNN. * Clear violet, with white centers; extralarge flower. Height 23 in. $\$ 1.60$ per doz., $\$ 12$ per 100 .

SCYLLA. Fiery red; a striking variety. Height 26 in. 75 cts. per doz., $\$ 5.50$ per 100 , $\$ 50$ per 1,000 .

SIERAAD VAN FLORA.* Bright red with a blue base; magnificent flower of a distinct color. Height 28 in. $85 ̛$ cts. per doz., $\$ 6.50$ per $100, \$ 60$ per 1,000 .

SIR HARRY VEITCH. Rich blood-red, blue base; large, bold flower; very good forcer. Height 22 in. 80 cts. per doz., \$6 per 100, \$5๊ per 1,000.

SUZON.* Center of petals buff-rose, shading to blush at the margin, with white base, delicately marked blue. Height 25 in. $\$ 1$ per doz., $\$ 7$ per 100 , $\$ 65$ per 1,000 .

THE SULTAN. Maroon-black. Height 25 in. 75 cts. per doz., \$5 per 100 , \$45 per 1,000 .

VALENTIN. Light violet, with electric-blue center; large and bold flower. Height 30 in. $\$ 1.60$ per doz., $\$ 12$ per 100 , $\$ 100$ per 1,000 .

WEDDING VEIL. Creamy white, slightly flushed lilac, with a clear white base and black anthers. Height 24 inches. 75 cts. per doz., $\$ 5.50$ per 100 , $\$ 50$ per 1,000 .

WHITE QUEEN. or LA CANDEUR. White. Can be called the only white Darwin. It opens rosy white, but passes to pure white. One of the most popular varieties; forces easily. Height 24 in. 75 cts. per doz., $\$ 5.50$ per 100 . $\$ 50$ per 1.000 .
WILLLAM COPELAND.* The best early forcing Darwin. May be flowered to perfection early in January; its color. when forced, is a delicate lavender. Height $25 \mathrm{in.} \$ 1$ per doz., $\$ 7$ per $100, \$ 65$ per 1,000 .

WILLIAM PITT.* Very dark crimson, with purplish bloom on the outer petals. Height 24 in. $\$ 1$ per doz., $\$ 7.50$ per $100, \$ 70$ per 1,000 .

ZANZIBAR. Rich glossy maroon; large fine flower. Height ¿১ 1u. \$1.10 per doz., \$\$ per 100 .

ZULU.* Blue-black ; very distinct form ; a splendid and very remarkable flower. Height 32 in. $\$ 1$ per doz., $\$ 7.50$ ver $100, \$ 70$ per 1,000 .

BODDINGTON'S QUALITY MIXED. A fine mixture of all the best named varieties. 75 cts. per doz., $\$ 5$ per 100 ,
45 per 1,000 .

BODDINGTON'S MIXED. 55 ets. per doz., $\$ 3.75$ per 100 , $\$ 35$ per 1,000 .

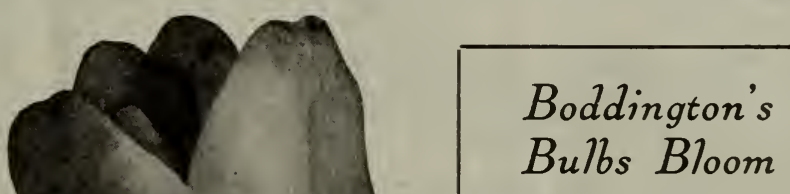




\section{OLD ENGLISH, FRENCH AND FLEMISH COTTAGE TULIPS (May-Flowering) "Expecially desirable for the}

\section{NEW LILY-FLOWERED TULIPS}

These new Tulips are the result of hybridizing Tulipa retroflexa with a pink Darwin variety. The result is a sturdy growing form with large, substantial flowers that still retain the form and elegance of retroflexa, all segments reflexing a little at the tips.

ADONIS. Long flower with reflexed petals, vivid rosy red.

ARTEMIS. Long stemmed, elegantly reflexed petals, bright carmine rose with pure white base.

MARVEL. Very distinct, sweet scented variety, inside old gold, outside salmon-rose edged yellow.

SIREN. First Class Certificate R. H. S. London. A very beautiful flower. The color is rich cerise pink with pale pink at the margins of the segments and a white base.
All the above $\$ 1.10$ each, $\$ 12$ per doz., $\$ 95$ per 100.

AVIS KENNICOTT. A large, long, chrome yellow flower; one of the best; height 25 in. 80 cts. per doz., $\$ 6$ per 100 , $\$ 55$ per 1,000 .

BIZARRES MIXED. Handsome flowers, feathered and striped with crimson, brown, purple or black on a yellow
ground. Height averaging about 20 in. 75 cts. per doz., $\$ 5.50$ per 100 , $\$ 50$ per 1,000 .

BOUTON D'OR. Has deep, clear yellow, globular, mediumsized blossoms, with curious, black-anthered stamens. Height 20 in. 70 cts. per doz., $\$ 5$ per $100, \$ 45$ per 1,000 .

BYBLOEMS, ROSE SHADES MIXED. Remarkably beautiful Tulips, blotched, striped and feathered with rose and crimson on a white ground. Heights average about 20 in. 75 cts. per doz., $\$ 5.50$ per $100, \$ 50$ per 1,000 . BYBLOEMS, VIOLET SHADES MIXED. Curious and purple, violet, blue or black on a white ground. Heights averaging about 20 in. 75 cts. per doz., $\$ 5.50$ per $100, \$ 50$ per 1,000 .

CALEDONIA. Bright orange. Height 20 in. 75 cts. per doz., $\$ 5$ per $100, \$ 45$ per 1,000 .

CARNATION. White, changing to rose. An improved form of Picotee; larger and more handsome. Height 22 in. 75 cts. per doz., $\$ 5$ per $100, \$ 45$ per 1,000 .

CHAMELEON. Pale heliotrope, flaked maroon on a canaryyellow ground. Height 20 in. \$6 per doz., \$45 per 100.

COLUMBUS. (Gala Beauty.) Blotched vermilion and golden jellow. Height 20 in. $\$ 1.60$ per doz., $\$ 12.50$ per 100.

CYCLOPS. Scarlet, with yellow center and black anthers. Height 24 in. 70 cts. per doz., $\$ 5$ per $100, \$ 45$ per 1,000 . CYGNET. White, with black anthers, very distinct. Height 20 in. 70 cts. per doz., $\$ 5$ per $100, \$ 45$ per 1,000 .

DORIS. Large globular flower, lilac-rose; suffused silver grey. Height 24 in. 75 cts. per doz., $\$ 5.50$ per 100, $\$ 50$ per 1,000 .

ELEGANS. Dark crimson, beautifully reflexed. Height 15 in. 75 cts. per doz., $\$ 5$ per $100, \$ 45$ per 1,000 .

ELEGANS ALBA. (White Crown.) Large white reflexed petals, margined rosy red. Height 20 in. 80 cts. per doz., $\$ 6$ per $100, \$ 55$ per 1,000 .

ELEGANS LUTEA PALLIDA. (Leghorn Bonnet.) Large Primirase yellow flowers, slightly reflexed. Height 20 in. 75 cts. per doz., $\$ 5$ per $100, \$ 45$ per 1,000 .

FAIRY QUEEN. Rosy heliotrope, broadly margined yellow, very large. Height 20 in. 75 cts. per doz., $\$ 5$ per 100, $\$ 45$ per 1,000 .

FLAVA. Beautiful soft lemon-yellow. Hine for massing in beds of a single color. Height 25 in. $\$ 1.60$ per doz., $\$ 12$ per 100 .

FULGENS. Bright crimson with white center, long and reflexed. Height 24 in. 60 cts. per doz., $\$ 4$ per 100 , $\$ 35$ per 1,000 .
GESNERIANA SPATHULATA. Beautifully curved flowers brilliant scarlet, with a bluish black center, on tall stems. Height 24 in. 75 cts. per doz., $\$ 5$ per $100, \$ 45$ per 1,000 .

GESNERIANA MACROSPEILA. Urimson-scarlet, blapk and yellow center. Height 24 in. 75 cts. per doz., \$5 per $100, \$ 45$ per 1,000 .

GESNERIANA LUTEA. Chrome yellow; tall and handsome. Height 24 in. 75 cts. per doz., $\$ 5$ per $100, \$ 45$ per 1,000 .

GESNERIANA IXIOIDES. Pale yellow, with black center. Height 22 in. $\$ 1$ per doz., $\$ 7.50$ per $100, \$ 70$ per 1,000 .

GLARE OF THE GARDEN. A large flower of glowing dark crimison-scarlet; petals very long, the outer ones reflexing. Height 18 in. $\$ 1$ per doz., $\$ 7$ per $100, \$ 65$ per 1,000 .

HOBBEMA. (LeReve, Sara Bernhardt.) Old rose suffused with buff, a very large globular flower with rounded petals carried on a strong stem. Height 13 in. $\$ 1$ per doz., $\$ 7.50$ per $100, \$ 70$ per 1,000 .

INGLESCOMBE SCARLET. Brilliant scarlet, black base. Height 20 in. 75 cts. per doz., $\$ 5$ per 100 , $\$ 45$ per 1,000 .

INGLESCOMBE YELLOW. Large, canary-yellow. Height 21 in. 75 cts. per doz., $\$ 5$ per $100, \$ 45$ per 1,000 .

INGLESCOMBE PINK. Une of the best pink sorts. Height 24 in. 75 cts. per doz., $\$ 5$ per 100. $\$ 45$ per 1.000 .

ISABELLA. (Shandon Bells.) Rose color, flaked with white, changing to a suffused deep rose and red. Height 20 in. 75 cts. per doz., $\$ 5$ per $100, \$ 45$ per 1.000 .

JOHN RUSKIN. A large apricot-pink with a border of yellow, blending softly into the petals. Height 18 inches. $\$ 1$ per doz., $\$ 7.50$ per 100 , $\$ 70$ per 1,000 .

LA MIFRVEILLE. Large, sweet-scented blossoms. Salmonrose, overlaid with orange-red. Height 20 in. 75 cts. per doz., $\$ 5$ per $100, \$ 45$ per 1,000 .

LEGHORN BONNET. (Elegans lutea pallida.) Large primrose yellow flowers, slightly reflexed. Height 20 in. 60 cts. per doz., $\$ 4$ per 100, $\$ 35$ per 1,000 .

MAIDEN'S BLUSH. (Picotee.) Clear white. margined on the edge with pink, changing to a deep rose. Height 20 in. 75 cts. per doz., $\$ 5$ per $100, \$ 45$ per 1,000 .

MISS WILMOTT. The flowers open canary yellow, gradually changing to bright golden yellow. Height 18 in. 75 cts. per doz., $\$ 5$ per $100, \$ 45$ per 1.000 .

MOONLIGHT. Bright canary yellow, large oval flower, outer petals reflexed at tip. Height 22 in. 85 cts. per doz., $\$ 6.50$ per $100, \$ 60$ per 1,000 .

MRS. KERRELL. Light rose, with delicate amber tinge : center white, bordered electric-blue. Height 18 in. $\$ 4$ per doz., $\$ 30$ per 100 .

MRS. MOON. Golden yellow; beautifully reflexed petals. Height 25 in. 75 cts. per doz.. $\$ 5.50$ per 100 , $\$ 50$ per 1.000 . DRANGE KING. Deep orange, shaded rose, sweet scented, a globular flower of great size. Height 23 in. 75 cts. per doz., $\$ 5$ per $100, \$ 45$ per 1,000 . 
OLD ENGLISH, FRENCH AND FLEMISH COTTAGE TULIPS (May-Flowering)-Continued

PARISIAN YELLOW. (Annie.) Bright yellow with orange yellow edge, large pointed flower. Height $20 \mathrm{in}$. 75 cts. per doz., $\$ 5$ per 100 , $\$ 45$ per 1,000 .

PARISIAN WHITE. (La Candeur.) White, passing to light pink. Height 16 in. 75 cts. per doz., $\$ 5$ per 100 , $\$ 45$ per 1,000 .

PRIMROSE BEAUTY. Soft primrose, changing to white. Height 16 in. 75 cts. per doz., $\$ 5$ per $100, \$ 45$ per 1,000 .

QUAINTNESS. Old gold flushed deep rose, a large tlower with very long petals. Height 24 in. $\$ 4$ per doz., \$30 per 100 .

ROYAL WHITE. Pure white with yellow center. Height 15 in. 75 cts. per doz., $\$ 5.50$ per $100, \$ 50$ per 1,000 .

STRIPED BEAUTY. Rose, flaked deep crimson and white. Height 18 in. 75 cts. per doz., $\$ 5.50$ per 100 , $\$ 50$ per 1,000 .
THE FAWN. Very large, oval flower; light grayish rose, changing to soft rosy white. Height 20 in. 75 cts. per doz., $\$ 5$ per $100, \$ 45$ per 1,000 .

THE LIZARD. Purple and yellow tiamed and feathered. Height 18 in. 70 cts. per doz., $\$ 5$ per 100 , $\$ 45$ per 1,000 .

UNION JACK. (Distinction.) Light violet, feathered purple, with a few white stripes. Height 20 in. $\$ 1$ per doz., $\$ 7$ per $100, \$ 65$ per 1,000 .

VITELLINA. Pale primrose, passing off to pure white. Height 20 in. 75 cts. per doz., $\$ 5$ per $100, \$ 40$ per 1,000 .

BODDINGTON'S “QUALITY” SUPERFINE MIXTURE OF MAY-FLOWERING TULIPS, for acclimating and for planting in herbaceous or shrubbery borders. 60 cts. per doz., $\$ 4.50$ per 100 , $\$ 40$ per 1,000 .

\section{REMBRANDT TULIPS}

Rembrant Tulips are simply queerly striped and feathered Darwin Tulips. 'They resemble Bybloems, but are larger, and there is more variety in the colors. They range in height from 18 to 22 in.

APOLLO. Lilac-rose and white, striped dark carmine. 80 cts. per doz., $\$ 6$ per 100 , $\$ 55$ per 1,000 .

CARACALLA. White, striped and feathered carmine-red; a very attractive variety. 80 cts. per doz., $\$ 6$ per 100 , $\$ 55$ per 1,000 .

EROS. Soft lilac, feathered dark violet; not a large, but an

JULIENNE. Rose, striped and feathered carmine-purple and white. Edges of petals broadly blotched white; makes splendid contrast with the rich mlor of the flower. $80 \mathrm{cts}$. per doz., $\$ 6$ per 100 , $\$ 55$ per 1,000 .

LA COQUETTE. Violet, flamed purple and white; not a large but an exquisite flower. 80 cts. per doz., $\$ 6$ per 100 , $\$ 55$ per 1,000 .

MARCO SPADO. White, flamed bright carmine-red; large flower. 80 cts. per doz., $\$ 6$ per $100, \$ 55$ per 1,000 .

SEMELE. White, heavily striped and feathered vivid rosy pink. A Tulip of exquisite coloring; large flower. 80 cts. per doz., $\$ 6$ per 100 , $\$ 55$ per 1,000.

VICTOR HUGO. Brilliant carmine, feathered white; large flower. 80 cts. per doz., $\$ 6$ per $100, \$ 55$ per 1,000 .

REMBRANDT TULIPS, CHOICE MIXED VARIETIES. 75 cts. per doz., $\$ 5$ per $100, \$ 45$ per 1,000 .

\section{PARROT TULIPS}

Three-Year-Old Flowering Bulbs

Parrot Tulips flower in May. 'Their marvelously striped and colored petals have slashed edges. The bulbs should be planted not more than 4 inches apart, as they are rather shy bloomers.

ADMIRAL DE CONSTANTINOPLE. Large, red flowers, tipped with orange. 75 cts. per doz.. $\$ 5$ per $100, \$ 45$ per 1,000 .

CRAMOISI BRILLIANT. Deep carmine; very handsome. 75 cts. per doz., $\$ 5$ per $100, \$ 45$ per 1,000 .

LUTEA MAJOR. Large; bright yellow, with crimson and green stripes. 75 cts. per doz., $\$ 5$ per $100, \$ 45$ per 1,000 .

MARKGRAVE OF BADEN. Yellow. striped with scarlet and green. 75 cts. per doz., $\$ 5$ per $100, \$ 45$ per 1,000 .

PERFECTA. Yellow and red, striped. 75 cts. per doz., $\$ 5$ per $100, \$ 45$ per 1,000 .

RUBRA MAJOR. Blond-red; handsome. 75 cts. per doz., $\$ 5$ per $100, \$ 45$ per 1.000 .

MIXED PARROT TULIPS. 60 cts. per doz., $\$ 4.50$ per $100, \$ 40$ per 1,000 . exquisite flower. 80 cts. per doz., $\$ 6$ per $100, \$ 55$ per 1,000 .

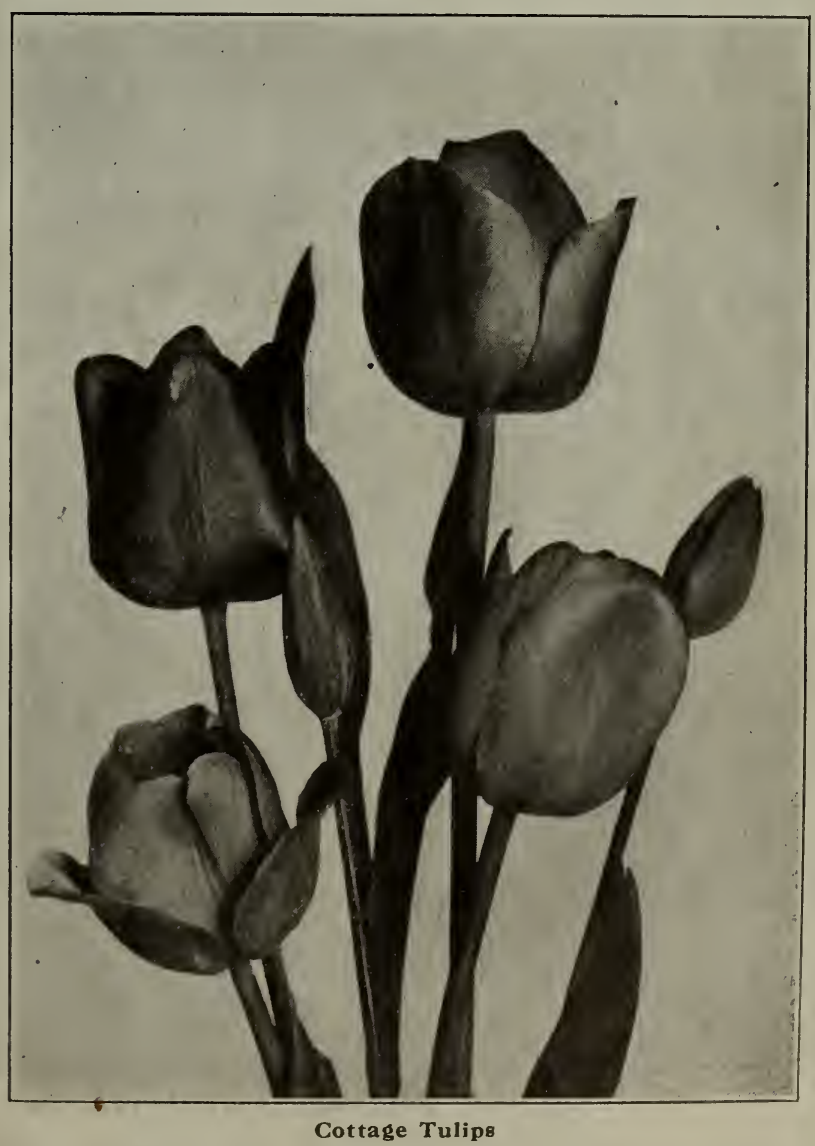




\section{OLD DUTCH BREEDER TULIPS}

To those in search of the unusual for group-planting in the perennial border, the Breeder Tulips (flowering in late May) present a fascinating choice. 'The most refined and artistic color combinations and soft blendings and graduations of purple, butt, bronze, maroon, and terra cotta are here revealed to the garden enthusiast exploring this class.

Breeder Tulips are noticeably sweet scented. 'Lhey are closely allied to the Darwins and some of the varieties bear even larger flowers and are of more vigorous growth than that well-known class. Cultural direction same as for Darwin 'Iulips. Apricot. Dull bronzy buff, shaded deep apricot, base olive-

Bacchus. Dark violet-blue; inside violet-blue with white in late Tulips. Still high in price on account of scarcity. Height 28 in. $\$ 10$ per doz॰, $\$ 80$ per 100.

Bronze Queen. Soft buff, inside tinged golden bronze ; Exquisite color when forced. Height 24 in. 85 cts. per doz., $\$ 6.50$ per $100, \$ 62$ per 1,000 .

Cardinal Manning. Dull wine-red, flushed rosy bronze ; 75 cts. per doz., $\$ 5$ per $100, \$ 45$ per 1,000 .

Chestnut. (La Nuit). Very dark brown, almost black: sorts of the Cottage Tulips. Height 24 in. 85 cts. per doz., $\$ 6.50$ per 100 , $\$ 60$ per 1,000 .

Coridion. Clear yellow, overlaid with stripe of lilac through $\$ 22$ per 100.

Dom Pedro. A unique shade of coffee-brown, shaded maroon, inside rich mahogany; large flower. Height 21 in. $\$ 2.50$ per doz., $\$ 20$ per 100

Faery. (Panorama.) Reddish mahogany, with bronze acter. Height 24 in. $\$ 1.80$ per doz., $\$ 12.50$ per $100, \$ 120$ per 1,000 .

Feu Ardent. Crimson-red, with mahogany shading; large doz., $\$ 10$ per 100 .

General Ney. Dull old-gold, with olive base; large. $\$ 95$ per 1,000 .

Golden Bronze. Light brownish yellow, with a faint flush brown within shadin of helintrope nutside; deep mahogany per doz., \$12 per 100 .

Heloise. Vandyke-brown, shaded old-rose; inside Vandykeolive-green ; large flower. Height 28 in. $\$ 6$ per doz., $\$ 40$ per 100.

\section{BODDINGTON'S “QUALITY"}

The value of Double Tulips lies largely in their lasting qualities. They lack the length of stem and grace of the singles; nevertheless, we know of no Tulips more beautiful than some of the Doubles, especially when flowered in pots or pans. They cannot be flowered so early as the Singles, and no attempt should be made to force them into bloom before the middle of March. F'or cultural directions see Single Early Tulips. When forcing Double Tulips let them come slowly at first, to prevent green tips.

\section{Double Red}

Imperator Rubrorum.* $3 \mathrm{M}$. Handsome scarlet; showy and lasting. $\$ 1$ per doz., $\$ 7.50$ per $100, \$ 70$ per 1,000 .

Vuurbaak.* 3 м. Brilliant scarlet. \$1 per doz., $\$ 7.50$ per 100 . $\$ 70$ per 1,000 .

Le Matador. 3 3 . Brilliant scarlet. $\$ 1$ per doz., $\$ 7$ per 100 , \$65. per 1,000 .

\section{Double Yellow}

Couronne d'Or.* $\overline{\text { (Crown of Gold.) }} 3$ м. Yellow, tinged old-gold; one of the finest for forcing, either for pots or pans. Makes a brilliant effect when massed in a large bed. $80 \mathrm{cts}$. per do $3 .$. \$6 per 100 . $\$ 55$ per 1.000 .

Golden King. $\$ 1.25$ per doz.. $\$ \$$ per 100 , $\$ 76$ per 1,000 .

Tournesol Yellow.* 3 D. One of the best double yellows. Very large flowers; fine for late bedding. $90 \mathrm{cts}$. per doz. $\$ 6.50$ per $100, \$ 62$ per 1.000 .

Tea Rose.* (Safrano. Brimstone.) 3 M. Soft Safrano-yellow shade, light orange at the tips of the petals. $\$ 1$ per doz., \$7 per 100 , \$65 ner 1.000 .

\section{Double Pink}

Couronne des Roses (Crown of Roses). 3 m. Delicate rose. \$1 per doz.. \$7 per 100, \$65 per 1,000.

La Grandesse.* 3 ir. Deep rose. 75 cts., per doz., $\$ 5.50$ per 100 , $\$ 50$ per 1.000 .

Lord Beaconsfield. 3 s. Deep rose. 75 cts. per doz. $\$ 5.50$ per 100 . $\$ 50$ per 1,000 .
Jaune d'Oeuf. Ruddy apricot, inside soft yellow, with variety. Height 21 in. 75 cts. per doz., $\$ 5.50$ per $100, \$ 50$ per 1,000 .

Louis XIV. Dark purple, with a broad margin of golden starred yellow. Height 30 in. \$6 per doz., \$45 per 100.

Lucifer. Clear orange, with a rosy flush and olive base, stem. Height 24 in. \$2 per doz., \$15 per 100.

Madame Lethierry. Crushed strawberry edged and cts. per doz., $\$ 6$ per $100, \$ 55$ per 1,000 .

Plutarchus. Bronze, overlaid with dull lilac, inside shaded Height 26 in. $\$ 2.50$ per doz., $\$ 15$ per 100.

Prince of Orange. Orange-scarlet, edged lighter red ; 85 cts. per doz., $\$ 6.50$ per $100, \$ 60$ per 1,000 .

Queen Alexandra. Canary-yellow, broadly flushed petals, inside clear yellow with black anthers. Height 23 in. 75 cts. per doz., $\$ 5$ per $100, \$ 45$ per 1,000 .

Turenne. Purplish brown, with a broad margin of soft per doz., $\$ 15$ per 100 .

Velvet King. Dark, glossy purple-maroon, with a white ing an extra number of petals and snlendid lasting qualities. Height 28 in. $\$ 3$ per doz., \$22 per 100.

Yellow Perfection. Light bronze-yellow. edged golden yelA large flower. Height 24 in. $\$ 1$ per doz., \$7 per 100.

Dutch Breeder Mixture. A fine mixture of many vaing producer of this type of Tulip. 75 cts. per doz., $\$ 5$ per $100, \$ 45$ per 1,000 .
Lucretia. $3 \mathrm{M}$. Splendid deep pink. $75 \mathrm{cts}$, per doz., $\$ 5.50$ per $100, \$ 50$ per 1,000 .

Murillo.* 3 м. Magnificent blush-white. 75 cts. per doz. $\$ 5.50$ per $100, \$ 50$ per 1,000 .

Rose d'Amoux.* 3 м. Beautiful soft rose. 70 ets. per doz. $\$ 4.75$ per $100, \$ 45$ per 1,000 .

Salvator Rosa.* $3 \mathrm{M}$. Deep rose, striped white. $\$ 1$ per doz.. \$7 per 100. \$65 per 1.000 .

\section{Double Striped and Oddly Colored}

Tournesol, Red and Yellow.* 3 D. 85 cts. per doz., $\$ 6.50$ per $100, \$ 60$ per 1.000 .

El Toreador.* 3 s. Bright, scarlet, margined buff-yellow fine forcer. $\$ 1.50$ per doz., $\$ 10$ per $100, \$ 96$ per 1.000 .

\section{Double White}

Boule de Neige.* 3 м. Pure white; one of the finest. 75 cts. per doz., $\$ 5.50$ per $100, \$ 50$ per 1,000 .

La Candeux. 3 ir. Pure white. 75 cts. per doz., $\$ 5.50$ per $100, \$ 50$ per 1,000 .

Schoonoord. A pure white sport from Murillo; perhaps the best double white. 75 cts. per dnz., $\$ 5.50$ per 100 . $\$ 50$ per 1,000 .

\section{Superfine Mixed Double Tulips}

60 cts. per doz., \$4 per $100, \$ 37$ per 1,000 . 


\section{SINGLE EARLY TULIPS}

Cultural Drections.-Tulips in Pots and Pans. Seven bulbs planted in a 6-inch pan are very satisfactory. It is important in the pot culture of Tulips to have rich, light soil. Cover the hole in the pot with a piece of broken pot, and over this place a half-inch layer of moss or grass roots which will keep the soil from clogging the drainage thus provided. In potting, place each bulb so that its top shall be half an inch below the surface of the soil and an inch below the rim of the pot. The soil should be of usual natural moisture and should be pressed moderately firm. The filled pots may be placed in a coldframe where there is protection from frost or in the coolest part of the celler; keep well watered. An excellent plan is to place them on a bed of moist, sifted coal-ashes, covering the pots to a depth of 6 inches with the same material. When well rooted, which will be in about twelve to fourteen weeks, the bulbs may be brought indoors and forced. For the first two or three weeks they should be kept in a temperature not exceeding 50 degrees. Success in forcing depends much on their having strong roots before being brought to the light. The top grows rapidly, and unless the roots are started much in advance they are unable to nourish the plant, and failure results. Tulips for forcing must be potted in September or October. The varieties followed by a star (*) are the best for forcing.

Outdoor Culture. There is one important difference between Hyacinths and Tulips. Under similar treatment most Hyacinths flower about the same time, while Tulips come into bloom at successive periods. The divergence has frequently been the source of much disappointment, for, in a bed (or even a vase or pot) planted with different Tulips, one variety may be overblown before the others show their colors.

The figures following the varieties indicate earliness in flowering, No. 1 being the earliest; No. 2 following; No. 3 , being still a little later, but coming into bloom before the No. 2 's are out. The height is indicated by " $D$ " for dwarf, " $M$ " for medium, "T" for tall. Tulips for bedding should be planted about 6 inches apart and about 4 inches deep, reckoning from the tops of the bulbs.

Arrangements of Color Schemes for Bedding.-For brilliant bedding effects, solid masses of color are to be preferred, especially for design bedding. We suggest the following combinations:

Prince of Austria and Vermilion Duchesse de Parma and La Reine. Brilliant.

Chrysolora and Belle Alliance.

Couleur Cardinal. Bedded by itself La Reine and Artus.

Maes. Unsurpassed when bedded alone. makes one of the most beautiful beds.

Pottebakker White and Chrysolora.

Pink Beauty and Ophir d'Or.

Rose Gris-de-Lin. Separate in one bed. Keizerskroon. Makes a unique bed. Cramoisi Brilliant and Ophir d'Or.
Apollo.* 3 T. Deep blood-red, changing to Doz. $100 \quad 1000$ claret as the flower ages............ \$1.30 $\$ 10.00 \$ 95.00$ Artus. 2 D. Dark scarlet...........75 $5.00 \quad 45.00$

Belle Alliance* 2 D. Scarlet; good blushing Bride (Mme. Frylink)* $2 \ddot{\mathrm{M}}$. Very bright pink $\ldots \ldots$.................. scarlet; improved Vermilion Brilliant. .

Cardinal Rampolla.* 1 M. Clear yellow, bordered bright orange-red...

Cerise Gris-de-Lin. 3 M. Dark carmineviolet, shaded fawn and margined white.

Chrysolora.* 2 M. Pure yellow......... Color white, striped red. Very early.. Cottage Boy. 2 D. Bronze-yellow. with

Cottage Maid.* 2 D. Pink, white striped .75

Couleur Cardinal. 3 T. Crimson-scarlet 1.00 Cramoisi Brilliant. 3 T. Bright scarlet 1.00

Cullinan.* 2 T. Rosy pink............ orange-scarlet. Real orange when forced.10.00

Duchesse de Parma. 2 M. Orange-red,

yellow shaded; large flower. $\ldots \ldots \ldots \ldots$. . . . .

Duc Van Thol, Red and Yellow. $1 \mathrm{D}$. Fine for very early effects...................

Duc Van Thol, White (Maxima).* $1 \mathrm{D}$. White

Duc Van Thoi, Yellow. $i$ D. Golden..

Dusart. $2 \mathrm{M}$. Deep vermilion; very large Flamingo.* 2 M. Carmine-rose, whiteshaded

Golden Queen.* 2 T. Pure yellow......

Goldfinch.* 2 D. Pure yellow.

Jaune Aplatie. 2 M. Pale sulphurJellow, flushed rose $\ldots \ldots \ldots \ldots \ldots \ldots \ldots \ldots$....

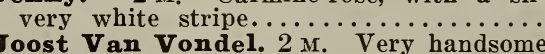
oost Van Vondel. 2 M. Very handsome
red, feathered white. $\ldots \ldots \ldots \ldots \ldots \ldots \ldots$.

Keizerskroon. 2 T. Red, with broad

King of the $\mathbf{Y}$ ellows. 2 T. Deep golden yellow

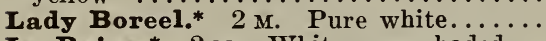

La Reine.* 2 м. White, rose-shaded...

La Reine Maximus. $2 \mathrm{~m}$. White, roseshading off to silvery pink at the edges. $\$ 1.00$ Le Matelas.* $2 \mathrm{M}$. Bright rose, white edge 1.00 Le Reve* (Hobbema; Sarah Bernhardt). 3 T. Old-rose, flushed buff ; a very large globular flower; strong stem. . 1.00

McKinley.* 2 т. Silky rose, shaded car-

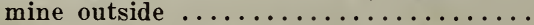

Maes.* 1 M. Bright scarlet; large flower Max Havelaar.* 2 M. Blood-orange, flushed salmon-rose............... 1.00 Mon Tresor.* 2 M. Pure yellow; large cup 1.00

Ophir d'Or. 2 м. Rich golden yellow.. .80

Pink Beauty. $3 \mathrm{~T}$. Deep glowing rose, with white flush on outer petals....... 1.00

Pottebakker Scarlet.* 2 T. Bright scarlet .75

Pottebakker White.* 2 T. Pure white. 1.00

Pottebakker Yellow.* 2 T. Large.... .75

President Lincoln.* 2 M. Clear magentaviolet; large flower; very effective when grown beside a light yellow Tulip......

Prince of Austria.* $3 \mathrm{~T}$. Orange-vermilion; large ; fine for forcing or bedding Proserpine.* 2 M. Large, rich, silky rose ; early forcer $\ldots \ldots \ldots \ldots \ldots \ldots \ldots \ldots$ order of early Tulip Flamingo, but of greater substance and keeping qualities.

Queen of the Netherlands.* 2 M. Deli-

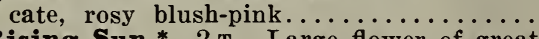

Rising Sun.* $2 \mathrm{~T}$. Large flower of great substance on tall stem; color deep golden yellow

Rose Gris-de-Lin. 2 D. Delicate pink.

Rose La Reine (Cherry Tulip).* $3 \mathrm{M}$. Deep carmine-rose .....................

Rose Luisante. $3 \mathrm{M}$. Deep pink.......
Rosa Mundi Huyckman. $3 \mathrm{M}$. Bright pink; feathered white...............

Sir Thomas Lipton. 2 T. Brilliant scarlet

Stanley.* 3 M. Rosy carmine ; large flower
Fred. Moore. 2 T. Apricot-orange ; fine

Fred. Moore. 2 T. Apricot-orange ; fine

Vermilion Brilliant.* 2 D. Bright ver-

milion $\ldots \ldots \ldots \ldots \ldots \ldots \ldots \ldots \ldots$ Pure white ; early.

White Swan. (True.) 2 T. Pure white

Wouverman. 2 $\mathrm{M}$. Dark violet.......

Yellow Prince.* 2 D. Pure yellow.....

Boddington's Fine Mixed Single Tulips. An extra-fine mixture.......
$100 \quad 1000$

$\$ 7.00 \$ 65.00$

8.0078 .00

$\begin{array}{ll}7.50 & 70.00\end{array}$

$5.50 \quad 50.00$

$5.00 \quad 45.00$

$7.50 \quad 70.00$

$7.50 \quad 72.00$

$6.00 \quad 53.00$

$\begin{array}{ll}7.50 & 66.00\end{array}$

$5.00 \quad 45.00$

$7.00 \quad 65.00$

$5.50 \quad 50.00$

$\begin{array}{lll}.80 & 6.00 & 53.00\end{array}$

$\begin{array}{lll}75 & 5.00 & 45.00\end{array}$

$\begin{array}{lll}1.50 & 9.50 & 92.00\end{array}$

7.00

65.00

$\begin{array}{lll}.60 & 4.50 \quad 40.00\end{array}$

$2.00 \quad 16.00$

$5.00 \quad 45.00$

1.00
1.00

7.00

65.00

$7.00 \quad 65.00$

$\begin{array}{lll}.60 & 4.50 & 45.00\end{array}$

$\begin{array}{lll}.75 & 5.50 & 50.00\end{array}$

$\begin{array}{lll}70 & 5.00 & 45.00\end{array}$

.75

$5.00 \quad 45.00$

$6.50 \quad 60.00$

$6.50 \quad 60.00$

$5.00 \quad 45.00$

$5.00 \quad 45.00$

$5.00 \quad 45.00$

$3.50 \quad 30.00$ 


\section{MISCELLANEOUS BULBS}

The varieties marked with an asterisk $\left({ }^{*}\right)$ are not hardy, and must not be subjected to frost

\section{AMARYLLIS}

On receipt of the bulbs in the autumn they should be placed where they will be always slightly moist and warm, under the benches of a greenhouse, for example; do not pot up the bulbs before the flower buds appear; when first potted, give very little water, and promote growth by giving moderate bottom heat; increase the supply of water as the plants progress. Very often the mistake is made that bulbs are potted up too early; the consequence is that only leaf-growth is made. The proper soil for Amaryllis is turfy loam enriched with rotten manure.

Vittata Hybrids, Boddington's Seedlings.* These seedlings contain some wonderful varieties, almost equal to named sorts. We can recommend them with the utmost confidence. Large bulbs $\$ 1.50$ each, $\$ 15$ per doz., $\$ 100$ per 100.

Hallii. (Hardy.) (The Magic Lily of Japan.) A perfectly hardy Amaryllis, producing beautiful pink flowers. In early spring attractive green foliage appears which grows until July, when it ripens off and disappears, and anyone not familiar with its habits would think the bulb had died; but about a month later. as if by magic, the flower stalks spring from the ground to a height of 2 or 3 feet, developing an umbel of large and beautiful lily-shaped flowers, 3 to 4 inches across, and from eight to twelve in number, of a delicate lilac-pink, shaded with clear blue. As the bulb is perfectly hardy without any protection, it can be planted either in the fall or spring. Cover the crowns about 4 inches. Very useful for the hardy border or among shrubbery. Strong, flowering bulbs, 60 cts. each, $\$ 6$ per doz., $\$ 40$ per 100 .

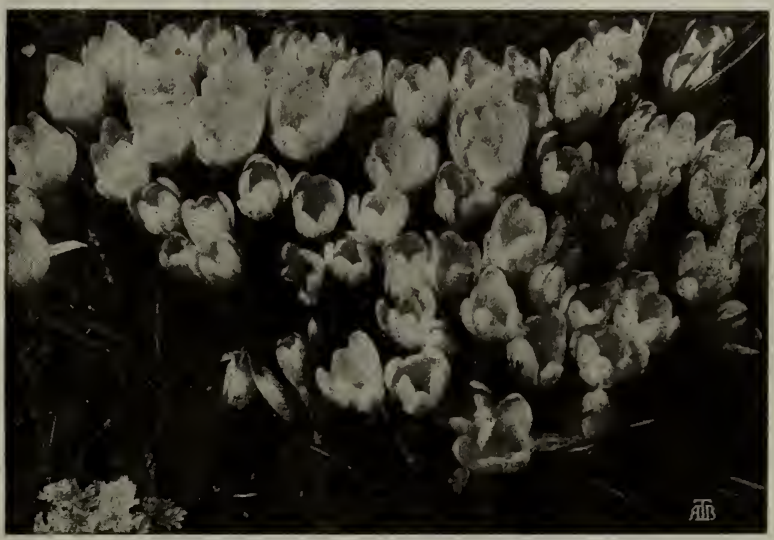

Boddington's Spring-blooming Crocuses

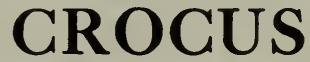

\section{SPRING-BLOOMING}

The bulbs should be set 3 inches deep, and should be planted in October or early in November to insure success. For a natural effect in the lawn they can be scattered in handfuls and planted where they lie.

\section{Boddington's "Quality" Crocuses \\ Doz. $100 \quad 1000$}

Albion. Blue. striped white......\$0.35 $\$ 2.60 \$ 23.00$

Baron von Brunow. Dark blue... $35 \quad 2.60 \quad 23.00$

Caroline Chisholm. White...... .35 2.60 23.00

Cloth of Gold. ............. . .35 $2.60 \quad 23.00$

Julia Culp. Large purple........ $.50 \quad 4.00 \quad 35.00$

Kathleen Parlow. Pure white.... $.50 \quad 4.00 \quad 35.00$

King of the Blues. Large blue. . $\quad .50 \quad 4.00 \quad 35.00$

$\begin{array}{lllll}\text { King of the Whites. Iargest white } & .35 & 2.60 & 23.00\end{array}$

La Majestueuse. White, violet

stripes $\ldots \ldots \ldots \ldots \ldots \ldots \ldots$

Mammoth Golden Yellow. Top

roots $\ldots \ldots \ldots \ldots \ldots \ldots \ldots \ldots \ldots \ldots \ldots$

Mont Blanc. Pure white......... .35 $2.60 \quad 23.00$

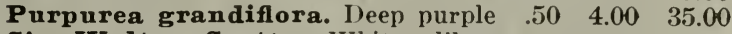

Sir Walter Scott. White, lilac-

striped .................... $35 \quad 2.60 \quad 23.00$

\section{Mixed Crocuses}

Large Golden Yellow. Very fine. $\begin{array}{llll}25 & 1.75 & 15.00\end{array}$

$\begin{array}{lllll}\text { Large Golden } \text { Yellow. } & & & \\ \text { Large Striped. Various shades.... } & .25 & 1.75 & 15.00\end{array}$

Large White. Various shades.... . . .25 $1.75 \quad 15.00$

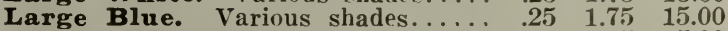

Large Mixed. All colors............. $.25 \quad 1.75 \quad 15.00$

DIELYTRA spectabilis (Bleeding-Heart). One LL I flowering plants, with elegant green foliage and long, drooping racemes of heart-shaped flowers of deep pink. 30 cts. each, $\$ 3$ per doz., $\$ 20$ per 100 . 


\section{6 $\quad$ Arthur T. Boddington Co., Inc., 128 Chambers St., New York City}

\section{LILY-OF-THE-VALLEY}

CULTURAL DIRECTIONS

New crop Lily-of-the-Valley should always be frozen before forcing.

If they are not to be forced immediately, they must be stored in a temperature as near freezing as possible and a natural condition of moisture maintained about the roots. New crop Lilyof-the-Valley may be forced into bloom in a temperature of 60 to 65 degrees in twenty-five days. Plant the roots half an inch apart, in sand or our prepared fiber. The propagating bench in the greenhouse may be used for this purpose, or 6 in. pots. Lily-of-the-Valley can be flowered by the amateur very satisfactorily in the living-room. We however recommend Coldstorage Pips for this purpose.

Outdoors Lily-of-the-Valley will succeed and always look well in shady places where it is difficult to get other plants to grow. "Boddington's "Wedding Bells." New crop-Novemdelivery. We offer extra strong pips of the German crowns grown in Holland. $\$ 2$ per bundle of $25, \$ 7.50$ per $100, \$ 70$ per 1,000 .

\section{Lily-of-the-Valley from Cold Storage}

Will flower in eighteen to twenty-one days after planting. Soak in water for six or eight hours, then pot or box up, and place in a temperature of 60 to 70 degrees, as directed above.

For many customers we ship a small quantity weekly. $\$ 3$ per bundle of $25, \$ 9$ per $100, \$ 80$ per 1,000 .

\section{GALLAS*}

Athiopica and The Godfrey may be successfully flowered in a sunny window in the early spring, if potted in the autumn. Elliottiana may be flowered in March and April under the same conditions, or may be planted in the open ground early in May and will produce a profusion of bloom throughout the summer. The roots must be lifted in the autumn and stored in a frost-free, dry place over the winter.

Calla Ethiopica (White Calla Lily). Too well known to need description. Dry roots, with center shoots ready for forcing. $13 / 4$ to 2 inches in diameter........\$0.25 $\$ 2.50 \quad \$ 20.00$

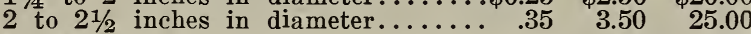
Monster .................. $45 \quad 4.50 \quad 35.00$ The Godfrey. A miniature white Calla ;

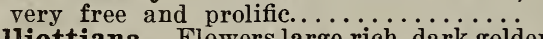
Elliottiana. Flowers large rich, dark golde

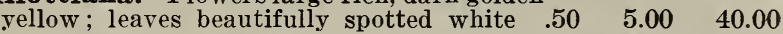

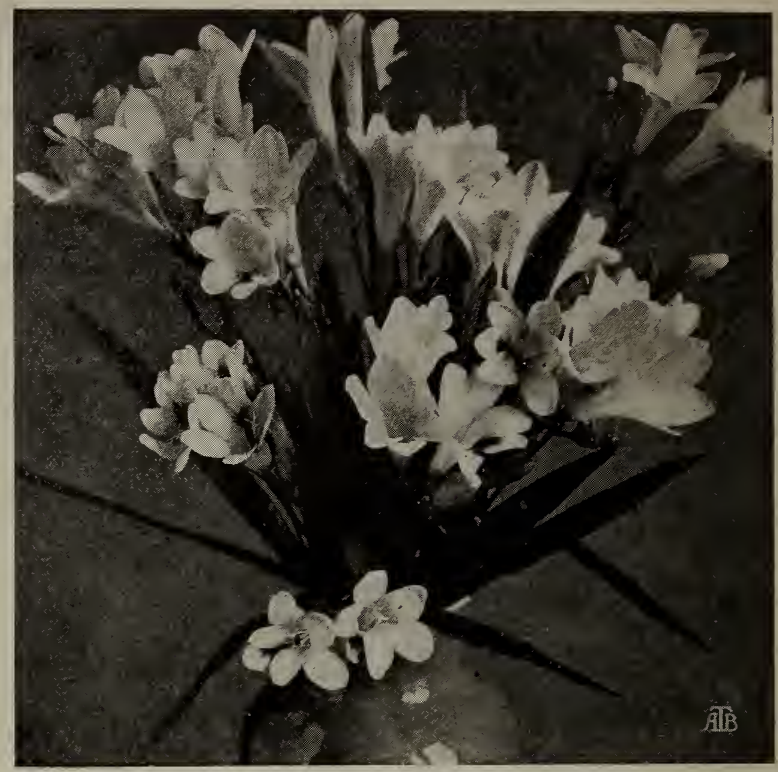

Boddington's Rainbow Freesias

\section{FREESIAS*}

If planted early, they may be had in bloom by Christmas. Plant eight or ten bulbs in a 6-inch bulb pan, covering them 1 inch.

FREESIA FISCHERI. (New.) The larg-

est pure white Freesia in cultivation. This

variety represents the result of 14 years

hybridization and selection by Mr. Fischer, Doz. $100 \quad 1000$

the celebrated Freesia specialist......... \$1.00 $\$ 8.00 \$ 75.00$

Fischer's Blue-Lavender .......... 1.3510 .00

Fischer's Mauve-Lavender . . . . . . . 1.3510 .00

Mrs. Chas. Hamilton. Soft Lavender-pink 2.0015 .00

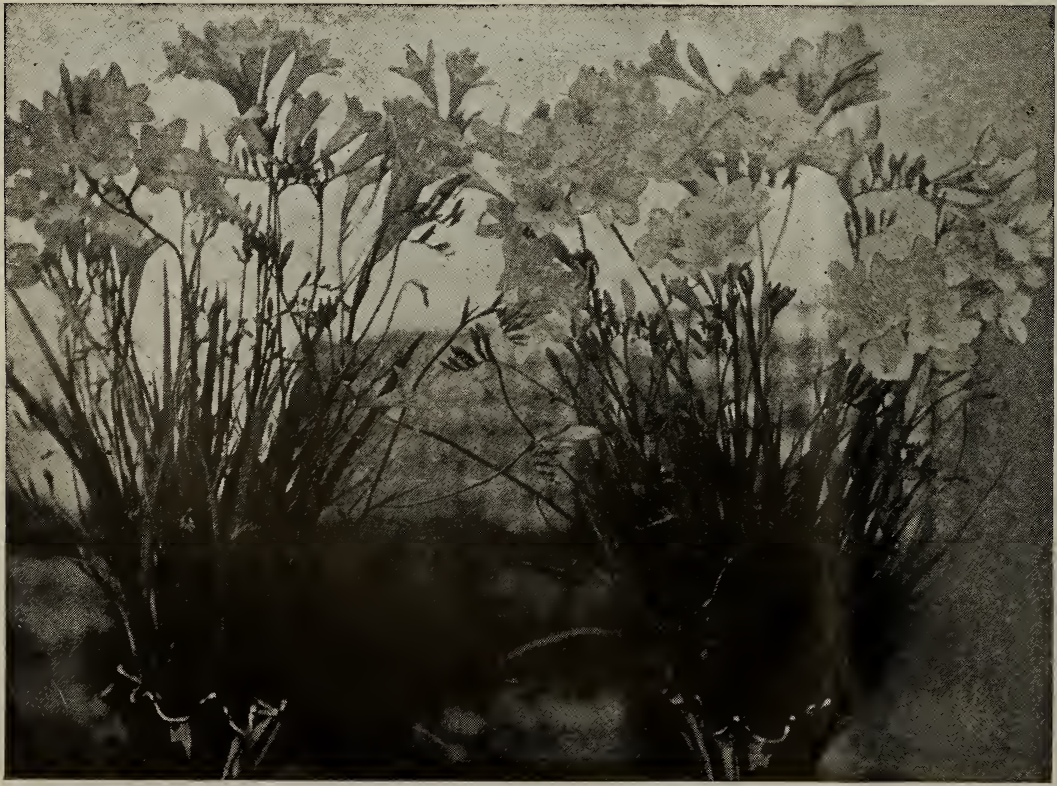

Blue-Lavender Fischer's Freesias
Mauve-Lavender
Mrs. Chas. Pike. Large, wide open flower. A half-inch band of mauvelavender encircles the edge of the white ground. $\$ 2$ per doz., $\$ 15$ per 100 .

Katharine Watkins. Not quite so large as the above, but of good substance; color salmon-buff. $\$ 2$ per doz., $\$ 15$ per 100 .

\section{Boddington's Rainbow}

A new race of colored Freesias which has created a sensation wherever shown. A mixture of various shades of lavender, orange, pink, yellow, etc. $\$ 1$ per doz., $\$ 7.50$ per 100 .

In separate shades. Yellow. blue and violet, mauve, pink, lavender. $\$ 1.35$ per doz., $\$ 10$ per 100 .

\section{Freesia, Fischer's Purity}

The flowers, which are snowy white, of large size, are borne in great profusion on stems 2 to $21 / 2$ feet, which grow upright and stiff; are excellent for cut flower purposes. First size, 40 cts. per doz., $\$ 2.50$ per $100, \$ 20$ per 1,000 . Mammoth bulbs, 60 cts. per doz., $\$ 4$ per $100, \$ 35$ per 1,000 . 


\title{
POT-GROWN STRAWBERRY PLANTS
}

\author{
SET OUT THIS SUMMER, WILL BEAR A FULL CROP OF BERRIES NEXT SPRING
}

Pot-grown Strawberry Plants are much superior to the ordinary ground layers usually sold, as there is no loss of fine roots in taking them up, consequently transplanting scarcely checks their growth; the earlier the pot-grown plants can be planted after July 20 , the larger they will grow, and the more they will produce the next Spring. We do not offer a long list of varieties in Strawberries, but only such as may be considered the best of existing sorts.

\section{ABOUT FORWARDING, TIME TO ORDER AND WHEN READY}

Strawberry plants are sent by express only at customer's expense, orders filled in rotation. Our first crop of plants will be ready about July 20, and if set out any time before September 15 they should grow into fine plants and bear a full crop of luscious fruit the next season.

Culture.-Strawberries require rich, well-tilled soil, the plants should be set 15 inches apart, in rows 2 feet apart; 100 plants will plant 4 rows, 30 feet long. Firm the plants well in the soil, keep thoroughly cultivated and cut off all runners. In the middle of December cover the beds to a depth of 3 inches with salt-meadow hay, straw or leaves. In April, as soon as the plants show an indication of growth, push the covering away from the plants to allow them to come up through. This mulching protects the plants from the cold in Winter and the heat in Summer, keeps the fruit clean, and prevents the growth of weeds.

PERFECT AND PISTILLATE STRAWBERRIES. The blossoms of Stawberries are either staminate (perfect-flowering) or are destitute of stamens and are termed pistillate (imperfect-flowering). Pistillate varieties must have a row of some perfect-flowering sort, flowering at the same time, planted every 10 or 12 feet apart among them, or, better yet, every third or fourth plant in the row to pollenize their blossoms. When properly pollenized, the pistillate varieties are usually the most prolific. Those marked with $\mathrm{P}$, are pistillate.

VARIETIES FOR FORCING -UNDER GLASS. We recommend for forcing under glass Marshall, Nick Ohmer and Chesapeake.

Abington. Midseason, vigorous habit. Bright red berries, solid and well flavored. $\$ 1.00$ per doz., $\$ 7.00$ per 100 .

Americus. Fall bearing. This variety fruits on Spring set plants, and on new runners from July to cold weather. If Autumn fruit is wanted the runners should not be removed. $\$ 1.50$ per doz., $\$ 10.00$ per $^{-1} 100$.

August Luther. Extra early, very prolific, dark red, firm berries, vigorous plant, succeeding on any soil. $\$ 1.00$ per doz., $\$ 7.00$ per 100 .

Bederwood. Early, immensely productive, berries large, bright red, deliciously flavored. $\$ 1.00$ per doz., $\$ 7.00$ per 100 .

Brandywine. Mid-season to late. Large, firm, solid, crimson berries, vigorous plant, succeeding on any soil. \$1.00 per doz., $\$ 7.00$ per 100 .

Chesapeake. Mid-season, large, one of the best in shape, flavor, size and color, dark color like Marshall. $\$ 1.00$ per doz., $\$ 7.00$ per 100 .

Early Jersey Giant. (Van Fleet No. 10). Early, perhaps the best of the early varieties, berries large, scarlet crimson, colors all over at once, vigorous grower and of finest flavor. $\$ 1.00$ per doz., $\$ 7.00$ per 100 .

Edmund Wilson. (Van Fleet No. 13). Mid-season, large globular berries of deep maroon color and finest flavor, enormously prolific. On good soil the plants attain a height of 12 to 15 inches. $\$ 1.00$ per doz., $\$ 7.00$ per 100 .

Commonwealth. Late, of the largest size, broadly coneshaped, fine flavored, juicy and dark colored. One of the best. $\$ 1.00$ per doz., $\$ 7.00$ per 100 .

Gandy. Late, in fact the standard late variety; a strong compact grower, large bright crimson, fruit firm and of finest flavor. $\$ 1.00$ per doz., $\$ 7.00$ per 100 .

Glen Mary. Mid-season. A standard market variety, fruit luscious, large, dark red. A strong grower. $\$ 1.00$ per doz., $\$ 7.00$ per 100 .

Joe. (Joe Johnson, Big Joe). Mid-season to late, resembles Chesapeake but unlike that variety, will succeed on almost any soil, deliciously flavored. $\$ 1.00$ per doz., $\$ 7.00$ per 100 .
Kellogg's Premier. Early, the large fruits begin ripening with the earliest varieties and continue until the latest varieties are at their best. Firm, richly colored, lusciously flavored. $\$ 1.00$ per doz., $\$ 7.00$ per 100 .

Kellogg's Prize. (P). A pistillate variety with a long fruiting season. Thrives on almost any soil, yielding very prolifically large highly colored berries with golden seeds. $\$ 1.00$ per doz., \$7.00 per 100 .

Marshall. Mid-season, one of the richest flavored Strawberries in existence, large size, dark colored. One of the best for greenhouse forcing. $\$ 1.00$ per doz., $\$ 7.00$ per 100 .

Nick Ohmer. Mid-season, one of the best for greenhouse forcing, vigorous, productive, deliciously flavored fruit of large size. $\$ 1.00$ per doz., $\$ 7.00$ per 100 .

Progressive. Fall bearing. Plants set out in August and September, fruit the next Spring and on the new runners formed, from July until frost. Berries deep crimson, firm, of high quality and flavor, about 1 inch in diameter. $\$ 1.50$ per doz., $\$ 10.00$ per 100 .

Senator Dunlap. Mid-season to late, very prolific, fruit large, dark red, and richly flavored. $\$ 1.00$ per doz., $\$ 7.00$ per 100 .

Success. Early, perhaps the earliest, large Strawberry, bright scarlet color of excellent flavor, abundantly productive and a vigorous grower. $\$ 1.00$ per doz., $\$ 7.00$ per 100 .

Sharpless. Mid-season. Demands a strong rich soil, strong grower, bearing large crimson, irregularly shaped berries, moderately firm and of good flavor. $\$ 1.00$ per doz., $\$ 7.00$ per 100 .

Steven's Late Champion. Late, it makes heavy foliage, affording ample protection to the fruit, which is bright red and of luscious flavor. $\$ 1.00$ per doz., $\$ 7.00$ per 100 .

Warren: Mid-season, strong grower, fruit large, well flavored and of handsome appearance. $\$ 1.00$ per doz., $\$ 7.00$ per 100 .

William Belt. Mid-season. A continuous cropper, berries large, handsome and full-flavored. $\$ 1.00$ per doz., $\$ 7.00$ per 100 . 


\section{- SEASONABLE FARM SEEDS}

Prices f. o. b. boat or railroad, New York, and are subject to market changes, bags extra at cost

\section{Winter Wheat}

JONES' CLIMAX. A hybrid originated by Mr. W. B. Jones, the famous wheat specialist of Batavia, New York. For four years this variety has proved to be especially adapted to Eastern conditions of soil and climate. It produces ten to twenty side shoots which all mature ears. The ears are both broad and long and bear frequently three and four grains to the mesh. Ears are smooth (not bearded) grain red, hard, rich in gluten and of the highest milling qualities. Sow $11 / 2$ bus. to the acre, may be sown as late as November 1st in New York State. Pk. $\$ 1.70$, bus. $\$ 5.75$.

JONES' RED WAVE. Smooth (not bearded) straw long, strong and clean, grains amber color, nearly round and of excellent milling qualities; very productive and the leading variety in $\mathrm{New}$ York and New England. Sow 2 bus. to the acre. Pk. $\$ 1.50$, bus. $\$ 5.25$.

LEAP'S PROLIFIC. Very strong straw, beardless; does not lodge down in storms, does well on light or heavy soils; large, hard. red berries, heavy yielder of excellent milling qualities. Sow 2 bus. to the acre. Pk. $\$ 1.50$, bus. $\$ 5.25$.

RUDY. This is perhaps the most popular of the bearded varieties of wheat for culture in New York and New England. By many farmers it is believed that this variety resists "smut" and other grain diseases in localities where the beardless varieties become affected with these troubles. The grain is red, hard, rich in gluten and of tlie highest milling quality. Sow $13 / 4$ bus. to the acre. Pk. $\$ 1.40$, bus. $\$ 4.50$

\section{Rye}

ROSEN RYE. Selected and improved by the Michigan Agricultural College. It is superseding common rye all over Michigan. The college reports following comparative yields: "Common rye, 4-year average for state, 16 bus.; Rosen rye, 25 bus.; Common, 4-year average, best growers, 20 bus.; Rosen, 32 bus. Rosen rye frequently yielded 40 bus. per acre." $\mathrm{Pk}$. $\$ 1.25$, bus. $\$ 4.50$.

MAMMOTH WINTER RYE. The heads average 6 to 8 in. in length and are filled from end to end with large, plump, heavy grains. The straw is giant in length and strength and of extraordinary stiffness, resisting severe wind and rain storms to a remarkable degree without lodging. Pk. $\$ 1.10$, bus. $\$ 4.00$; in 10 -bus. lots, $\$ 3.75$ per bus.

\section{Clovers}

ALFALFA, or LUCERNE (Dakota grown). Requires well-drained land, an abundance of lime in the soil and inoculation with the Alfalfa bacteria. Given these three essentials, it can be grown anywhere in the United States. It can be sown alone as late as September 1st in thoroughly prepared, deeply plowed soil, at the rate of 25 to $30 \mathrm{lbs}$. to the acre, in drills, if sown broadcast 30 to 40 lbs. per acre. The crop should be cut when the plant is coming into bloom. In suitable soil it is perennial, and several crops may be cut every year. Height 1 to $3 \mathrm{ft}$. Lb. $\$ 1.20,10$ lbs. $\$ 10.00,100$ lbs. $\$ 80.00$.

GRIMM ALFALFA. Is said to be much hardier than the regular Western variety, due to the fact that a large proportion of the plants have a crown which is a trifle submerged so that it is not so easily heaved out of the ground by the alternate freezing and thawing of our Eastern winters. It is also said to outyield the common Western Alfalfa. A considerable percentage of the plants of this variety bear a peculiar greenish, yellow flower. Lb. $\$ 1.25$, 10 lbs. $\$ 12.00,100$ lbs. $\$ 100.00$.

ALSIKE, or SWEDISH (Trifolium hybridum). Hardiest of all Clovers, and on rich, moist soil yields an enormous quantity of hay or pasture. Lasts many years. Sow 10 lbs. per acre when used alone. Lb. $\$ 1.00,10 \mathrm{lbs} . \$ 8.00,100 \mathrm{lbs} . \$ 75.00$.

RED CLOVER, MEDIUM (Trifolium pratense). Medium Clover The leading variety of Clover for pastures or meadows. Finest quality. Sow 20 lbs. per acre alone, or 15 lbs. where other gras or hay crops are standing. Lb. $\$ 1.00,10 \mathrm{lbs} . \$ 8.00,100$ lbs. $\$ 75.00$.

CRIMSON CLOVER (Trifolium incarnatum). Economical cover crop for using green or ploughing under. Lb. 45 cts., 10 lbs. $\$ 4.00,100$ lbs. $\$ 35.00$.

\section{GRASS SEEDS}

Grass seeds are sold in the trade by sample, and each sort is divided into three or four grades of quality, according to purity, germination and weight. The price of the best grade is often double that of the ordinary. The Grass seeds offered by us are in every case the very highest grade. We do not carry the lower grades, but can quote, if requested. Prices subject to change without notice. Special quotations on large quantities. $\begin{array}{llrrr}\text { BERMUDA GRASS (Cynodon dactylon) } \ldots . . \$ 1.25 & \$ 10.00 & \$ 95.00 \\ \text { CANADA BLUE GRASS (Poa compressa) } & . & .35 & 3.00 & 27.00\end{array}$ $\begin{array}{llllll}\text { ENGLISH RYE GRASS (Lolium perenne) .. } & .25 & 2.25 & 20.00\end{array}$ $\begin{array}{lllll}\text { ITALIAN R YE GRASS (Lolium Italicum)... } & .25 & 2.25 & 20.00\end{array}$ KENTUCKY BLUE GRASS (Poa pratensis). $.60 \quad \begin{array}{llll}6.00 & 45.00\end{array}$ MEADOW FESCUE (Festuca pratensis) ..... $\quad .65 \quad 6.00 \quad 50.00$ $\begin{array}{lllll}\text { MEADOW FOXTAIL (Alopecurus pratensis).. } & .70 & 6.50 & 60.00\end{array}$ $\begin{array}{lllll}\text { ORCHARD GRASS (Dactylis glomerata)..... } & .60 & 5.50 & 50.00\end{array}$ RED TOP FANCY, RECLEANED (Agrostis vulgaris)

RED TOP ÜNHÜLLED (Agrostis vulgaris). ROUGH STALKED MEADOW GRASS (Poa trivialis)

SWEET VERNAL (Anthoxanthum odoratum).

True perennial.

TALL FESCUE (Festuca elatior)

TALL OAT GRASS (Avena elatior)

TIMOTHY, or HERDS GRASS

$\begin{array}{lll}.40 & 3.50 \quad 30.00\end{array}$

$\begin{array}{lll}.40 & 3.50 & 30.00 \\ & 2.50 & 20.00\end{array}$

$\begin{array}{lll}.70 & 6.50 & 60.00\end{array}$

$\begin{array}{lll}.90 & 8.00 & 75.00\end{array}$

$\begin{array}{lll}70 & 6.50 & 60.00\end{array}$

$\begin{array}{lll}.70 & 6.50 \quad 60.00\end{array}$

$25 \quad 2.20 \quad 20.00$

\section{REGLEANED TIMOTHY}

Our stock of this is unusually large and of very good quality. Sow 25 lbs. per acre alone, or 15 lbs. with wheat or grasses. Lb. 25 cts., 10 lbs. $\$ 2.30,100$ lbs. $\$ 20.00$ (bus. 45 lbs.)

\section{GRASS MIXTURES FOR HAY AND PERMANENT PASTURE}

We make special mixtures, following the formulæ of the highest agricultural authorities to meet the following conditions:

HAY MIXTURE FOR LIGHT, MEDIUM OR HEAVY SOILS. PASTURE MIXTURE FOR LIGHT, MEDIUM OR HEAVY SOILS

Sow $50 \mathrm{lbs}$. to the acre, or more if land is poor. $10 \mathrm{lbs}$. $\$ 4.00$, 100 lbs. $\$ 35.00$.

\section{WINTER VETCH $\begin{gathered}\text { Vicia villosa } \\ \text { Sand, or Hairy Vetch }\end{gathered}$}

Extensively used as a soil renovator or for dry or green feed in the early Spring. It may be sown alone or with Winter rye or oats; perfectly hardy. When sown with rye, etc., it will attain a height of 4 to $5 \mathrm{ft}$.; it requires one-half bushel to sow an acre, or one bushel if sown alone. Sow as early as possible in the Fall or Summer and get a good growth before cold weather sets in. 60 lbs. per bus. Lb. 50 cts., 10 lbs. $\$ 4.50,100$ lbs. $\$ 40.00$.

\section{Millets For Summer Sowing}

\section{Excellent for Hay}

HUNGARIAN MILLET. The variety that matures most quickly Sow 1 bus. ( 50 lbs.) per acre. Lb. $\$ 0.25,10 \mathrm{lbs}$. $\$ 2.00,100$ lbs. $\$ 19.00$. GOLDEN MILLET. Coarser grower than Hungarian, heavier yielder but does not mature so quickly. Sow, 1 bus. (50 lbs.) per acre. Lb. 25 cts., 10 lbs. $\$ 1.80,100$ lbs. $\$ 15.00$.

JAPANESE MILLET. The coarsest of all the varieties and the heaviest yielder, but the latest of all to mature. Sow $12 \mathrm{lbs}$. per acre in drills 12 to 18 in. apart, or $15 \mathrm{lbs}$. per acre broadcast. Lb. 40 cts., 10 lbs. $\$ 3.50,100$ lbs. $\$ 30.00$.

\section{Buckwheat, Japanese}

The best variety. Sow 1 bus. to the acre. Peck $\$ 1.35$, bus. (50 lbs.) $\$ 5.00$. 
BODDINGTON'S "QUALITY" FLOWER SEEDS-Continued

\section{CENTAUREA IMPERIALIS Giant Sweet Sultan}

Magnificent flowers of brilliant color; for table decoration. Pkt. The Bride. Pure white $\ldots \ldots \ldots \ldots \ldots \ldots \ldots \ldots \ldots \ldots .25$

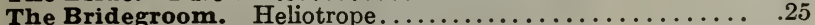

The Bridesmaid. Lemon-yellow ................. .25

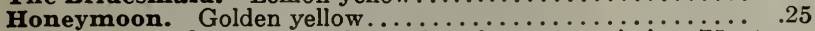
Collection. One pkt. each of the above 4 varieties, 75 cts.

\section{CYCLAMEN Boddington's}

Belle of Boston. (Roseum giganteum.) Bright rosy pink with cherry eye; we believe this to be the finest pink to date.

Bush Hill Pioneer. A beautiful feathered Cyclamen

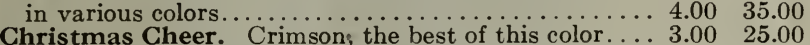

Daybreak. An exquisite shade of soft pink; very early. $3.00 \quad 25.00$

Eileen Low. A lovely shade of pink (Rose du Barri), with a distinct blush-white margin and blush-white crest on each petal. The plants are good growers and

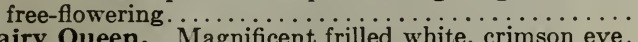

Fairy Queen. Magnificent frilled white, crimson eye.

Glory of Wandsbek. Shades of salmon......... 4.00

Lavender. Dark and light æsthetic shades.......... 3.00

Magnifica. Dark rose pink, very popular............. 3.00

$\begin{array}{lr}100 & 1000 \\ S e e d s & \text { Seeds }\end{array}$

Mrs. Buckston. Real salmon color, similar to the famous Carnation Enchantress. Produces most freely profusion of immense flowers with beautifully frilled petals. Strongly recommended...

Pride of New York. Semi-double salmon, large, free

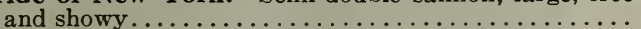

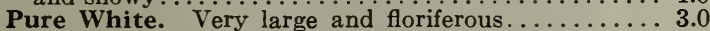

Rose of Marienthal. Soft shell-pink......

Rosea Superba. Deep shell-pink................. $3.00 \quad 25.00$

Victoria. White, tipped pink, fringed edge......... $3.00 \quad 25.00$

Wine Red. Immense flowers, very floriferous....... $3.00 \quad 25.00$

White, Pink Eye. Fine, large flower, very early and

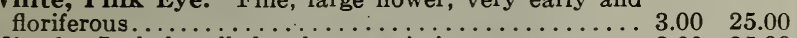

Mixed. Includes all the above varieties............ $3.00 \quad 25.00$

\section{MIGNONETTE For Greenhouse Culture}

Boddington's Majesty. The best of all Mignonettes for indoor forcing Easy to grow; strong constitution, throwing up a quantity of flower spikes which grow to an immense size. Seed saved from selected spikes grown under glass. Half pkt. 60 cts., pkt. containing about 500 seeds, $\$ 1.00,1 / 8$ oz. $\$ 1.50$.

Allen's Defiance. A popular variety for indoor culture, long spikes, very fragrant and fine for cutting Pkt. 25 cts., $1 / 8 \mathrm{oz} . \$ 1.00$.

\section{MYOSOTIS (Forget-Me-Not)}

Boddington's Pot. For flowering indoors at Christmas time. Sown in July and potted on, they produce fine free-growing specimen plants for Christmas. Pkt. 50 cts., 3 pkts. $\$ 1.25$.

Ruth Fischer Compact bushes, 12 in. in diameter, and literally covered with sprays of beautiful, heavenly blue Forget-me-not flowers. Pkt. 35 cts., 3 pkts. $\$ 1.00$.

Boddington's Royal Blue. Early and free blooming; flowers of the deepest indigo-blue produced in long sprays which are excellent for cutting Height 12 in. Pkt. 50 cts

\section{PRIMULA OBCONICA GIGANTEA}

This type of Primula outrivals the old Obconica type, the flowers being considerably larger, of ten measuring $11 / 2$ in. in diameter Kermesina. Rich crimson.\$0.25

Rosen

Alba...................... .25

Lilacina.. Lilac........\$ $\$ 0.25$

Eureka. Shades of crimson.

Forbesi (Baby Primrose). Beautiful rosy lilac flowers in seemingly never-ending profusion. Pkt. $25 \mathrm{cts}$.

Kewensis. Pleasing bright yellow flowers borne on long stems. It is delightfully fragrant and stands well as a house-plant. Pkt.

PRIMULA MALACOIDES (The Giant Baby Primrose). Light lilac can be had in bloom in four or five months after sowing. Pkt. $\$ 0.50,3$ pkts $\$ 1.25$.

Malacoides Superba. Deep rosy pink. Pkt. 50 cts., 3 pkts. .\$1.2.5 Malacoides Alba. Pkt. 25 cts., 5 pkts.

1.00

\section{PENTSTEMON GLOXINOIDES $\begin{gathered}\text { Boddington's } \\ \text { Hybrids H.H.P. }\end{gathered}$}

The varieties we offer are saved from large Gloxinia-shaped flowers, comprising the most varied colors from white to deepest crimson, with intermediate shades of rose-pink and lavender. Sow in fall for summer blooming. Pkt. 50 cts., 3 pkts. $\$ 1.25$.

Boddington's Pink Shades. On white grounds only. Pkt. 75 cts., 3 pkts. $\$ 2.00$.

\section{PANSIES Boddington's Giants}

Boddington's Challenge. This Challenge Mixture contains all the finest Giant strains of the leading Pansy specialists in the worldthe Giant self-colors, the Giant striped and margined, and the Giant blotched-all carefully mixed in proportion. Pkt. 50 cts., $1 / 4$ oz. $\$ 2.50,1 / 2$ oz. $\$ 4.25$, oz. $\$ 8.00$.

Boddington's English Exhibition Mixed. Contains some very unusual colors and markings. Pkt. 50 cts., $1 / 4$ oz. $\$ 7.50$.

Bugnot's Exhibition. Extra choice mixture. Pkt. $50 \mathrm{cts}$., $1 / 4 \mathrm{oz}$. $\$ 3.75$.

Cassier's. A fine strain of large flowers. Pkt. 50 cts., 1/4 oz. $\$ 2.50$.

Knott's Winter-Flowering Mixed. Giant flowers on long stems; good substance and beautiful colors. Pkt. 75 cts., 3 pkts. for $\$ 2.00,1 / 4$ oz. $\$ 7.50$

Masterpiece (Frilled Pansies). Petals beautifully waved. Exquisite colors. Pkt. 75 cts., $1 / 4$ oz. $\$ 2.50$.

Sim's Gold Medal Mixture. Was awarded the First Prize and Gold Medal at the International Horticultural Exhibition. Is undoubtedly the finest achievement in Pansy mixtures. Pkt. 75 cts., $1 / 4$ oz. $\$ 5.00$.

Trimardeau. Mammoth flowering mixed. Pkt. 25 cts., $1 / 4 \mathrm{oz}$. $\$ 2.00$.

Triumph of the Giants. A superb mixture of exceedingly large and beautifully marked Pansies. Pkt. 50 cts., $1 / 4$ oz. $\$ 3.00$.

Bath's Empress. A new mixture of fancy blooms of giant size. Colors brilliant and varied. Pkt. 75 cts., $1 / 4 \mathrm{oz}$. $\$ 5.00$. GIANT PANSIES IN SEPARATE COLORS

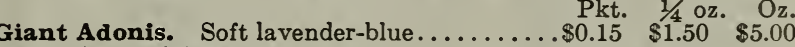

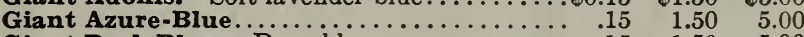

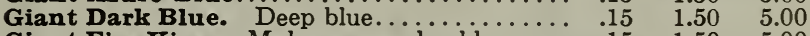

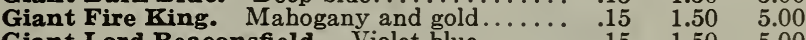

Giant Lord Beaconsfield. Violet-blue...... $.15 \quad 1.50 \quad 5.00$

Giant Purple ....................... $15 \quad 1.50 \quad 5.00$

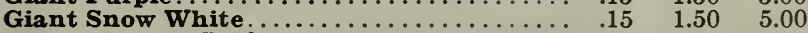

Giant White. Dark eye................... $15 \quad 1.50 \quad 5.00$

Giant Pure Golden Yellow............... $15 \quad 1.50 \quad 5.00$

Giant Yellow Dark eye.................... $15 \quad 1.50 \quad 5.00$ STOCKS, WINTER-FLOWERING

Abundance. Carmine-rose. Pkt. 25 cts., $1 / 8$ oz. $\$ 1.00$.

Empress Elizabeth. Splendid winter stock. Carmine rose. Pkt. 25 cts. $1 / 8$ oz. $\$ 1.00$.

Beauty of Nice. Daybreak-pink; one of the best. Pkt. 25 cts. $1 / 8$ oz. $\$ 1.00$.

Almond Blossom. Another fine new color of this splendid class. Pkt. 25 cts., $1 / 8$ oz. $\$ 1.00$.

Canary-Yellow. Undoubtedly the finest yellow stock yet raised. Height, 15 in. Pkt. 25 cts., $1 / 8$ oz. $\$ 1.00$.

Crimson King. Height 2 to $21 / 2 \mathrm{ft}$. Fragrant flowers of a brilliant, fiery crimson. Pkt. $25 \mathrm{cts}$., $1 / 8$ oz. $\$ 1.00$.

Empress Augusta Victoria. Color silvery lilac. Pkt. 25 cts., $1 / 8$ oz. $\$ 1.00$.

Princess Alice (Cut-and-Come-Again). Pure white. Pkt. 25 cts., $1 / 8$ oz. $\$ 1.00$.

Queen Alexandra. A splendid variety; flowers rosy lilac, Pkt. 25 cts., $1 / 8$ oz. $\$ 1.00$

WHITE LADY. Pkt. 25 cts., $1 / 8$ oz. $\$ 1.00$.

\section{FOUR NEW GIANT STOCKS Greenhouse}

The Lenox stocks are great improvements on the Beauty of Nice strain. They bloom in four to five months from sowing and under good cultivation (disbudded), attain a height of $21 / 2$ to $3 \mathrm{ft}$., producing a gigantic flower spike bearing beautiful large double flowers, the actual seed offered above has produced as much as 85 per cent doubles.
Lenox Pink
Lenox Mauve
Lenox White
Lenox Purple
Each color separate. Pkt. 25 cts., $1 / 8$ oz. $\$ 2.50$.

SCHIZANTHUS

Boddingtonii. Invaluable for cutting and excellent as a potplant. This strain is superior to any of the Schizanthus in cultivation. It has been for years the sensation of the International

Flower Show held in New York in the Spring. Pkt. \$1.00.

Wisetonensis. Mixed. Pkt. $75 \mathrm{cts}$.

Wisetonensis Rose and Amber Shades. Pkt. $\$ 1.00$. 


\section{Arthur T. Boddington Co., Inc., 128 Chambers St., New York City}

\section{WINTER-FLOWERING SPENCER SWEET PEAS}

CULTIVATION.- White-seeded varieties must be sown in sand in small pots, not in earth, or they will rot or "damp off;" later, transplant to the permanent position. Winter-flowering Sweet Peas should not be sown too thickly, about one ounce to 100 feet is sufficient. Thin out to about 3 inches apart when plants are about 6 inches high; if wanted for Christmas, sow before the end of August; if wanted during January, February and March, about the middle of October; if wanted for Easter, about the first of December. For successful growing a temperature of 40 to 45 degrees at night and 10 degrees higher in the day is considered best. Watch out for red spider, thrips, and green fly. Feed when plants are in full bloom.

\section{Australian Winter-Flowering Sweet Peas}

\section{ALBURY LAVENDER. Beautiful shade of lavender. ........} BLUE FLAKED. Rich deep blue, lavishly penciled over a delicate gray-white ground. One of the best CONCORD CHARM. White and blue-white wings, light heliotrope standard, shading to nearly white, of the best form.

CONCORD COUNTESS IMPROVED. Shell pink, graduating to a lighter tint at the base of the standard and wings.

CONCORD COQUETTE. White ground, faintly marked and mottled light rosy carmine, the standard showing the color rather than the wings; good stems, carrying three and four blooms

CONCORD DAYBREAK. On opening the bud is cream with standard heavily edged buff-pink. As the flower opens the cream changes to almost white, and the cream-pink edging to a faint rosy tinge; largest size and finest Spencer form. Stems long and wiry, carrying three and sometimes four on a stem. CONCORD EXQUISITE. Pale pink on rich cream ground three on stem, of perfect form.

CERULEA. A glorious Sweet Pea of the most delightful shades of delicate sky-line. Good open form, three on a stem..

CONCORD PURPLE. On first opening, a delightful shade of mauvy purple, changing, as the flower ages, to purple-blue. The flowers are enormous, of perfect Spencer form

CONCORD RADIANCE IMPROVED. A very striking shade of rosy magenta. First class as regards size, form, substance, and

CONCORD sNowBird. Pure white, largest size. Pkt. of 50 seeds $1 / 4 \mathrm{oz}$.

RUBY. A glowing light crimson-scarlet, blooms of good size, Spencer form, carried in threes, well placed on good, wiry stems, especially useful for Christmas flowering..

$\$ 0.50 \$ 1.00 \$ 3.00$

SALMONEA. A rich rosy salmon. Very freeflowering, it bears three and sometimes four blooms on a stem, of good size and form. CHRISTMAS PINK SHADES, CONCORD. A Spencer strain of the Christmas Pink coloring. Rosy cerise standard, creamy white wings, slightly tinted blush. There is at times some variation in these; so we offer as shades.

YARRAWA. (Originator's seed, Australiangrown.) Bright rose-pink, with lighter wings. Perhaps the most floriferous and popular variety

\section{American Varieties}

ASTA OHN, EARLY. Identical in color and
size of blossom to the well-known Summer-

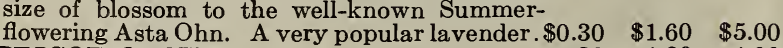

APRICOT ORCHID

SNOWFLAKE. Pure white. White seeded... $\quad .30 \quad 2.00 \quad 7.00$

CHRISTMAS PINK. Standard bright pink, wings white.

BOHEMIAN GIRL. Self pink, with light scarlet blush

GIANT EARLY LAVENDER (Early Songster)

CREAM. Identical in color and size of blossom to Dobbie's Cream.

MORNING STAR, EARLY. Deep orange scarlet

LIBERTY. Brilliant red.

MRS. WILLIAM SIM. Apricot pink

MRS. A. A. SKACH. Clear, bright pink

BLANCH FERRY SPENCER. Extra Early. Standard bright pink, wings white.
$.50 \quad 1.50$ 5.00

$\begin{array}{lll}.30 & 1.20 & 4.00\end{array}$

seeds $1 / 4 \mathrm{oz} . \quad \mathrm{Oz}$. $0.50 \$ 1.00 \$ 3.00$

$\begin{array}{lll}.50 & 1.00 & 3.00\end{array}$

$\begin{array}{lll}50 & 1.00 & 3.00\end{array}$

$\begin{array}{lll}50 & 1.00 \quad 3.00\end{array}$

$\begin{array}{lll}50 & 1.20 \quad 4.00\end{array}$

$\begin{array}{lll}.50 & 1.00 & 3.00\end{array}$

$\begin{array}{lll}.50 & 1.00 \quad 3.00\end{array}$

$\begin{array}{lll}50 & 1.00 & 3.00\end{array}$

$.50 \quad 1.00$

3.00

$50 \quad 1.00$

3.00

$\begin{array}{lll}50 & 1.00 & 4.00\end{array}$

\section{$\begin{array}{lll}.50 & 1.00 \quad 3.00\end{array}$}

$\begin{array}{lll}.50 & 5.00 \quad 18.00\end{array}$

$\begin{array}{lll}.30 & 1.00 & 3.00\end{array}$

$\begin{array}{lll}.30 & 1.60 & 5.00\end{array}$

$\begin{array}{lll}.40 & 1.00 \quad 3.00\end{array}$

$\begin{array}{lll}30 & 1.60 & 6.00\end{array}$

$\begin{array}{lll}.50 & 1.70 & 5.00\end{array}$

$\begin{array}{lll}.40 & 1.30 & 4.00\end{array}$

$\begin{array}{lll}.30 & 1.30 & 4.00\end{array}$

$\begin{array}{lll}.50 & 5.00 & 18.00\end{array}$ seeded. ter whiter.

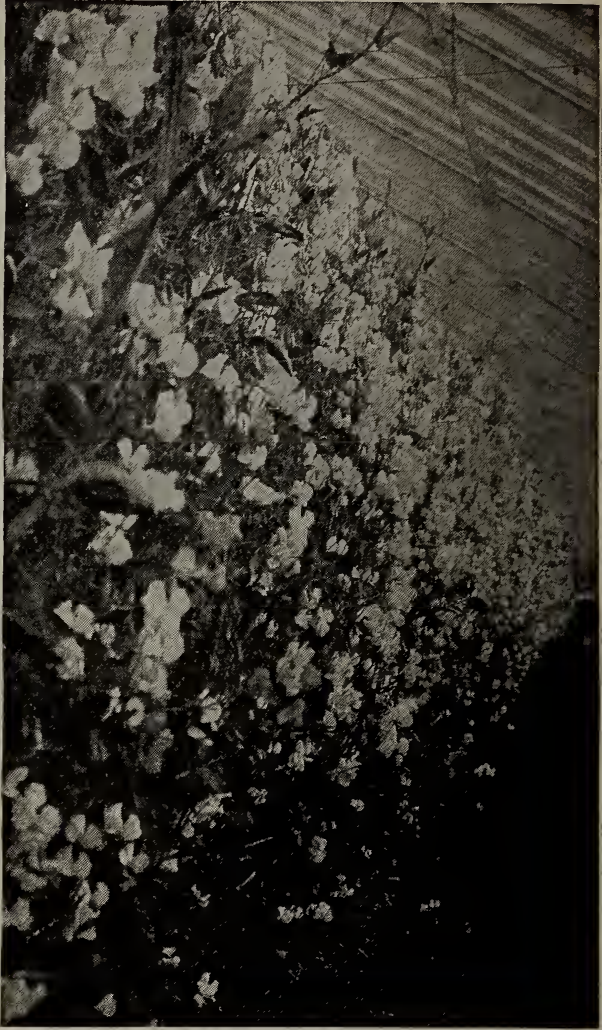

Boddington's Re-selected Winter-Flowering Spencers

HEATHERBELL EARLY. Rich lavender-

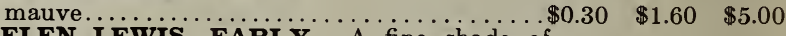

HELEN LEWIS, EARLY. A fine shade of salmon pink

HERCULES EARLY. Bright pink, large flower, long, heavy stem, heavy producer.

MELODY EARLY. Soft rose.

SONG BIRD EARLY. Light pink

SPRING MAID EARLY. Light pink on a cream ground

WEDGWOOD EARL Y. Bright clear blue...

MRS. M. SPANOLIN. Double, white. Black-

PINK-AND-WHITE ORCHID

ROSE QUEEN. A pink of sterling merit and of most pleasing shade. Size, length of stem, cannot be improved upon.

VENUS. Standard slightly blush-pink; in Win-

WHITE ORCHiD. Pure white; has stood the most critical tests.

$\begin{array}{lll}.30 & 1.60 & 5.00\end{array}$

$\begin{array}{lll}.30 & 1.60 & 5.00\end{array}$

$\begin{array}{lll}.30 & 1.60 & 5.00\end{array}$

$.30 \quad 1.60 \quad 5.00$

$\begin{array}{lll}.30 & 1.60 & 5.00\end{array}$

$\begin{array}{lll}.30 & 1.60 & 5.00\end{array}$

$\begin{array}{lll}.30 & 1.30 & 4.00\end{array}$

$\begin{array}{lrr}.50 & 5.00 & 18.00\end{array}$

$\begin{array}{lll}.50 & 2.00 \quad 7.00\end{array}$

$\begin{array}{lll}.30 & 1.30 & 4.00\end{array}$

$\begin{array}{lll}.30 & 1.30 & 4.00\end{array}$

\section{The New Crimson Spencer Sweet Pea} "EARLY AVIATOR"

This is the finest winter-flowering crimson-scarlet for Christmas cutting. An improvement on all existing varieties. True open Spencer form, a large flower of splendid substance on stout long stems carrying three and four blooms Pkt. (50 seeds) 50 cts., $1 / 4$ oz. $\$ 1.50$, oz. $\$ 5.00$.

\section{Mixed Spencers, Winter-Flowering}

Containing many of the best and most expensive sorts in a wide range of color. Pkt. (50 seeds) $30 \mathrm{cts}$., $1 / 4 \mathrm{oz} . \$ 1.00$, oz. $\$ 3.00$, $1 / 4$ lb. $\$ 11.00$. 


\section{Hardy Perennial and Old-Fashioned Flowers}

\section{THAT CAN BE PRODUCED FROM SEED SOWN IN SUMMER AND FALL}

Cultural Directions.-Penennial seeds sown in the summer and fall will flower the following year-spring, summer, or fall, according to the variety. The seed should be sown carefully, the same as any choice seed, in well-drained pots, or shallow boxes or pans. Soil should be light and fairly rich, with about one-eighth coarse sand added; after sowing, cover lightly with well-sifted soil. When the plants have become large enough to handle, "prick out" about 2 inches apart, more if you have the room, in shallow boxes or frames, and again, when large enough, set out in the open in well-prepared ground. If this is done in the fall, the young plants should be lightly covered with leaves or short stable manure; this will act as a slight protection, and will be conducive to their thriftiness and next season's growth.

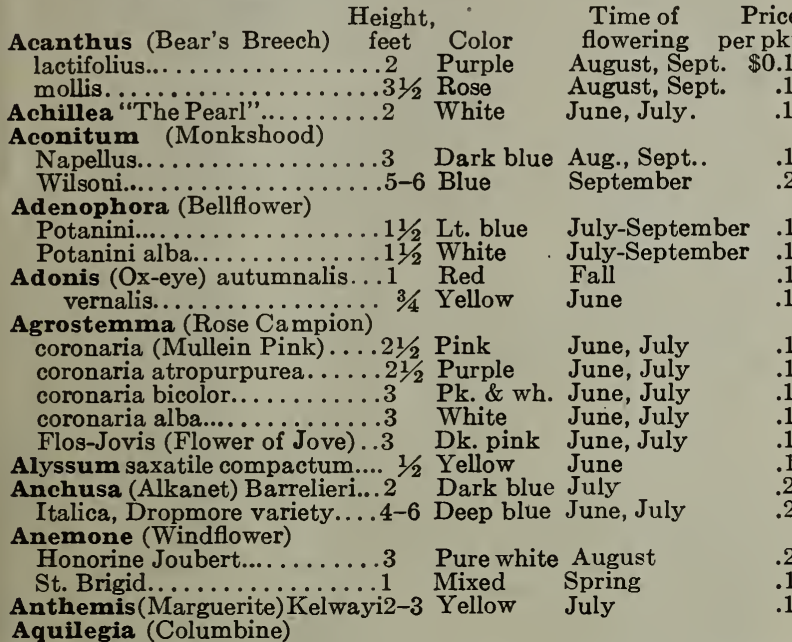

Boddington's Long-spurred

Hybrids..............

Californica hybrida..............

chrysantha...............

chrysantha grandiflora alba. .3

cærulea (Rocky Mt. Col)......3

Mrs. Scott Elliot's long spurred

Hybrids................

nivea grandiflora..........

Rose Queen...............

Skinneri hybrida $\mathrm{f}$. pl..........

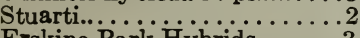

Erskine Park Hybrids.........

Arabis (Rock Cress) alpina......

Armeria (Thrift) formosa......

formosa alba ................

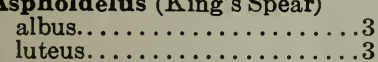

Aster (Michælmas Daisy)

Bessarabicus.............

Novæ-Angliæ..............

Novi-Belgii...............

Novi-Belgii, Purity........... .

subcæruleus.............

Townsendii...............

Astilbe Davidii...
Aubrietia (False Wall Cress)

Græca (trailing)........... 1/2 Purple Farly summer

Græca (trauling $\ldots \ldots \ldots \ldots \ldots \ldots \ldots \ldots \ldots \ldots \ldots 1 / 2$ Rosy car. Early summer $\quad .10$

Baptisia Australis.............

Mixed Summer 5 pkgs. 1.25

Mixed Summer $\quad .15$

Canary Summer $\quad .15$

$\begin{array}{lll}\text { White } & \text { Summer } & .15 \\ \text { Pale blue } & \text { Summer }\end{array}$

Mixed Summer $\quad .50$

Pure white Summer $\quad .15$

Rose Summer $\quad .30$

$\begin{array}{ll}\text { Dbl. crim. Summer } & .25 \\ \text { Pale blue Summer } & .50\end{array}$

Mixed col. Summer $1 / 40 z . \$ 1 \quad .15$

$\begin{array}{ll}\text { Pure white Spring } & .10 \\ \text { Rosy pink.Spring to Fall } \quad .10\end{array}$

White Spring to Fall .10

White Summer $\quad .10$

Yellow Summer

.10

Violet Fall

Blue, pur. Fall

Blue Fall

White Fall

Pale helio. Summer

Lilac July-October .15

Mauve Summer $\quad .15$

Bocconia (Plume Poppy)

Japonica.....................
Boltonia (Chamomile)

asteroides.............

latisquama.. Beilli.....

Carpatica colestina......

Media (Canterbury Beil)

White Summer

Flesh-color Fall

Pink, lav. Fall

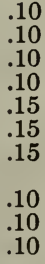

.10

Double White............. 3

Media, Double Blue............

Media, Double Lavender. ... 3

Media, Double Rose..........

Media, Double Mixed........

Media, Single Rose...........

Media, Single Blue...........

\begin{tabular}{|c|c|}
\hline $\begin{array}{l}\text { Blue } \\
\text { White }\end{array}$ & $\begin{array}{l}\text { Summer } \\
\text { Summer }\end{array}$ \\
\hline White & Summer \\
\hline Blue & Summer \\
\hline Lavender & Summer \\
\hline Rose & Summer \\
\hline All colors & Summer \\
\hline Rose & Summer \\
\hline Blue & Summer \\
\hline
\end{tabular}

\begin{tabular}{|c|c|c|c|}
\hline $\begin{array}{l}\text { Height, } \\
\text { feet }\end{array}$ & Color & Time of & $\begin{array}{r}\text { Price } \\
\text { per pkt. }\end{array}$ \\
\hline Media, Single white.... & White & Summer & $\$ 0.10$ \\
\hline Media, Single Striped... & Striped & Summer & .10 \\
\hline Media, Single Mixed. & All colors & Summer & 10 \\
\hline Media, Single Rosy Carmine. & Rose & Summer & .20 \\
\hline calycanthema(Cup andSaucer) 2 & Blue & Summer & 10 \\
\hline calycanthema alba..........2 & White & Summer & .10 \\
\hline calycanthema rosea..... & Bright rose & Summer & .10 \\
\hline calycanthema, Mixed.. & Various & & .10 \\
\hline persicifolia grandiflora.... & Blue & June, July & .25 \\
\hline $\begin{array}{l}\text { persicifolia grandiflora alba...4 } \\
\text { persicifolia grandiflora Mœr- }\end{array}$ & White & June, July & .25 \\
\hline aimi & $\mathrm{Dl}$ & Jul & .5 \\
\hline
\end{tabular}

pyramidalis (Chimney Bell-

flower)............... $\ldots \ldots \ldots$

pyramidalis compacta........

pyramidalis compacta alba...3

Catananche

Candytuft

Gibraltarica...

Sempervirens.

Blue

White

Blue
White

Late summer

Late summer

Late summer

11/2 Pale violet Summer

Centaurea (Cornflower)

montana.....................

Chelone (Turtle Head)

barbata coccinea............

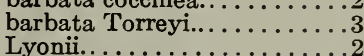

Chrysanthemum (Moonpenny Daisy)

maximum, Shasta..........11/2 White Summer

maximum, Triumph.......... 2 Pure white Summer

maximum, King Edward Vï...2 Glist.white Summer

White July
White

ematis (Virgin's Bower)

paniculata...........10-30

Coreopsis lanceolata grandiflora2

Cowslip (Primula officinalis) .... 1

Delphinium (Larkspur)

Belladonna (true) $\ldots . \ldots . \ldots 5$

Chinense..................

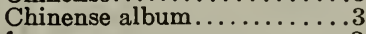

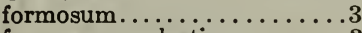

formosum cœlestinum.........

Dictamnus (Gas Plant, or

Burning Bush), Fraxinella..2

Fraxinella alba....

gloxiniæflora alba.

gloxiniæflora purpurea........

gloxiniæflora rosea..........

gloxiniæflora lutea.

gloxiniæflora, mixed..........

lanata....................

monstrosa, mixed..........

maculata Iveryana.

Echinacea-Helianthus

Hardy Red Sunflower.

Eremurus Himalaicus. . . . . . .

Bungei...............

Elwesianus..............

Robustus...

White Summer

Rich yel. Summer

Yellow Spring

Silvery bl. Summer

Mixed Sum. 5 pkts. $\$ 1$

Light blue Midsum.

White Midsum.

Dark blue Sum. Oz. $\$ 1.50$

Sky-blue Summer

$\begin{array}{ll}\text { Rosy lilac } & \text { June, July } \\ \text { White } & \text { June, July }\end{array}$

White

Purple

Rose

Summer

Yellow

Summer

Mixed Sum. Oz. 60c.

Purplish

Mixed

Spotted

Summer

Sum. Oz. 75c.

White Summer

Yellow Summer

White Summer

Rosy Pink Summer

Erinus alpinus.
Eryngium (Sea Holly)

amethystinum............ Amethyst Summer

Eupatorium (Thoroughwort)

ageratoides............. White

Gaillardia (Blanket Flower)

kermesina splendens........11/2 Crimson

sulphurea oculata.............11/2
Yellow

All colors
Aug., Sept.

Summer

Summer

Summer Oz.\$2
Late Summer
.15 
PERENNIAL SEEDS-Continued

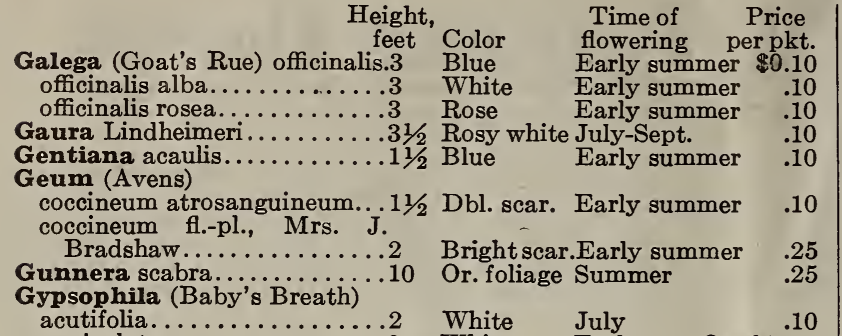

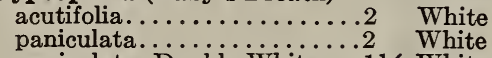
paniculata. ....
paniculata Double White....11/2 White
repens.................. White

Helenium (Sneezeweed) autumnale.............6 Yellow autumnale superbum.........6 Yellow Bigelowi.................. Yellow Hoopesii...................

Helianthus (Sunflower)

Perennial, Mixed............3-6 Various

Heliopsis (Orange Flower)

Pitcheriana.......................
Hesperis (Sweet Rocket)

matronalis, White.......... 3-4 White

matronalis, Lilac........... 3-4 Lilac matronalis nana candidissima.2 White matronalis, Mixed.........2 Mixed

Early sum.Oz. $\$ 1.10$

Jun.,Jul. 6pkts. $\$ 1.20$

Early summer .10

Heuchera (Alum Root)

sanguinea...................

Africanus, Crimson Eye......4

Golden Bowl. . .

moscheutos roseus.

Hollyhock (Mallow)

Boddington's Quality DoubleApple Blossom...........6

Bright Pink............6

Blood-red..............

Canary-yellow.............

Crimson.............6

Golden yellow........... 6

Lilac. .............6 6

Rose.................6.

Salmon.................

Scarlet..............

Snow-white...........6

Mixed.

Allegheny Mixed.

Single Finest Mixed

Chater's Choice Double Mxd.6

Iberis Gibraltarica............ 1

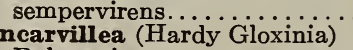

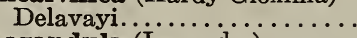

Lavandula (Lavender) vera. . . 11

latifolius, Pink Beauty.......10

latifolius roseus.............

Leontopodium (Alpine Sunflower, or Edelweiss)

alpinum

Linum (Flax) perenne...

Lobelia (Cardinal Flower)

cardinalis...... fulgens, Queen Victoria.......

Lupinus (Lupine) arboreus....4 arboreus, Snow Queen.......4 arboreus, New Hybrids Mixed4 polyphyllus. . . . . . . . . . . . $\ldots \ldots 4$

polyphyllus, Mixed polyphyllus, NewHybridsm $x d .4$

Lychnis (Campion)

Arkwrightii... .

Chalcedonica.

i...

$\ldots \ldots \ldots 2$

Haageana...............

Haageana fol. atropurpurea..1 Or.-scarlet May, June

viscaria splendens.........11/2 Deep pink May, June

Lythrum (Loosestrife)

roseum superbum.........31/2 Rose July-Sept.

moschata flora-alba........5 White $\begin{array}{ll}\text { Crimson July-Sept. } \\ \text { July-Sept. }\end{array}$
Late summer

Late summer

Late summer

June-Sept.

Midsummer

Midsummer

Midsummer

Coral-red Midsummer

Wh.\&crim. Midsummer

Yellow Midsummer

Midsummer

\section{.10 \\ .15}

.15

.10

Midsummer

Midsummer

Midsummer

Midsummer

Midsummer

Midsummer

Midsummer

Midsummer

Midsummer

Midsummer

.10

White July $1 / 8$ oz.50c..10

White July

Rose Midsummer

Midsummer

.10

Midsum. oz. 75c. .10

Midsum. oz. 75c. .10

Midsum. oz. 75c. .10

Midsumme

.10

Fiery red Au.,Sep.1/40z.\$1. .10

Scarlet August, Sept. $\quad .25$

Yellow June-Sept.

White June-Sept.

July-Sept.

Blue June-Sep. oz.50c. .10

Rose-pink June-Sep. oz. \$1. .10

Various June-Sep.oz.25c .10

June-Sept.

.25

.50

.10

.10

.10

.10

.10

.10
Late summer

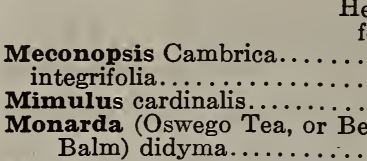
Balm) didyma...........

alpestris............. alpestris, Eliza Fonrobert......1/2 alpestris, Victoria......... dissitiflora................... semperflorens.............. Royal Blue............... Ruth Fischer..............

CEnothera (Evening Primrose)

Fraseri.................. fruticosa major.............

Lamarckiana................

rosea Mexicana............11/2

taraxacifolia alba.

Papaver (Poppy)

alpinum, Mixed.

bracteatum hybridum.

bracteatum Liverme

involucratum maximum......

Nudicaule (Iceland Poppy)

album .......................

croceum.................

Mixed.

orientale, Brightness.........

orientale, Brilliant............

orientale, Colosseum........4

orientale, Goliath........... 3

orientale, Grand Mogul.......3

orientale, Mammoth.........4

orientale, Parkmanni........ 3

orientale, Prince of Orange...3

orientale, Royal Scarlet......3

orientale, Salmon Queen.....3

orientale, Trilby...........3

Pentstemon (Beard-Tongue)

Boddington's Gloxinioides..... 3

Boddington's Pink Shades....3

Digitalis..................

pubescens.................

Phlox (Flame-Flower)

decussata, newest hybrids.....3
Physalis (Chinese Lantern Plant)

Franchetti................

Physostegia (False Dragon Head)
speciosa.................. speciosa................

Pink (Clove Carnation)

Mrs. Sinkins....... ; Ladder) $^{1}$

cæruleum album...........1 cæruleum grandiflorum.......1 Richardsonii...............

Polyanthus (Primula elatior)

Blue ................. 10 in

English (selected strain)...... 10 in. Mixed

Gold-laced, extra choice.... 10 in. Mixed

Giant White..............

Giant Yellow...............

Giant Crimson................

Giant Mixed.............

Polyanthus-Primrose (Bunchflowered). Large-fl'd., mixed.1 Munstead Giant Strain......1

Primrose, (Large-flowered).....1 English (Primula vulgaris)...1 Inglescombe.............

Primula

Japonica............. White officinalis (Cowslip).......... Yellow rosea.................. Ro in. Ro

Pyrethrum roseum.......... Rose Boddington's Hybrids, Single.2 Mixed Boddington's Hybrids, D'ble.2 Mixed

Rudbeckia (Coneflower) laciniata.............. J-5 Yellow July-September Neumannii...............

purpurea hybrida............ Purple July-September
Time of Price

flowering perpkt.

August, Sept. $\quad .50$

Summer

July-Sept.

.10

Blue Spring $\quad .10$

Spring $1 / 80 z .50$. 10

Blue Spring 10

Deep blue Spring 1/80z.50c. .15

blue Spr.Aut1/80z.40c. .10

$\begin{array}{lll}\text { Blue } & \text { Spring } 1 / 80 z .75 c . & .50 \\ & .35\end{array}$

Yellow June-Sept.

Gold. yel. June-August

Summer

Summer

Summer

Summer

Sum. 1/2 .10

oz. $\$ 1 . \quad .10$

Summer

Summer

Summer

Summer

Mix. colors Sum. oz. $\$ 1.50$

Scarlet Summer

Crimson Summer

Crimson Midsummer

Midsummer

Midsummer

Sum. 3 pkts. $\$ 2.00 .75$

wite June-August

Mixed June-August

.25

Or.-scarlet Fall

10

Midsummer

.10

Midsummer

White Summer

.50

White June-October

.10

Deep blue June-October

.10

pring $\quad .15$

Spring 1/4 oz. 50c. .10

Spring

Spring

Spring

Spring

Spring

Various Spring

Various Summe

Spring

Spring

Summer

Spring

Spring

Spring

Spring

Spring

Spring

.25
.15
.15

.15
.15
.25
Yellow June-August

Midsummer 


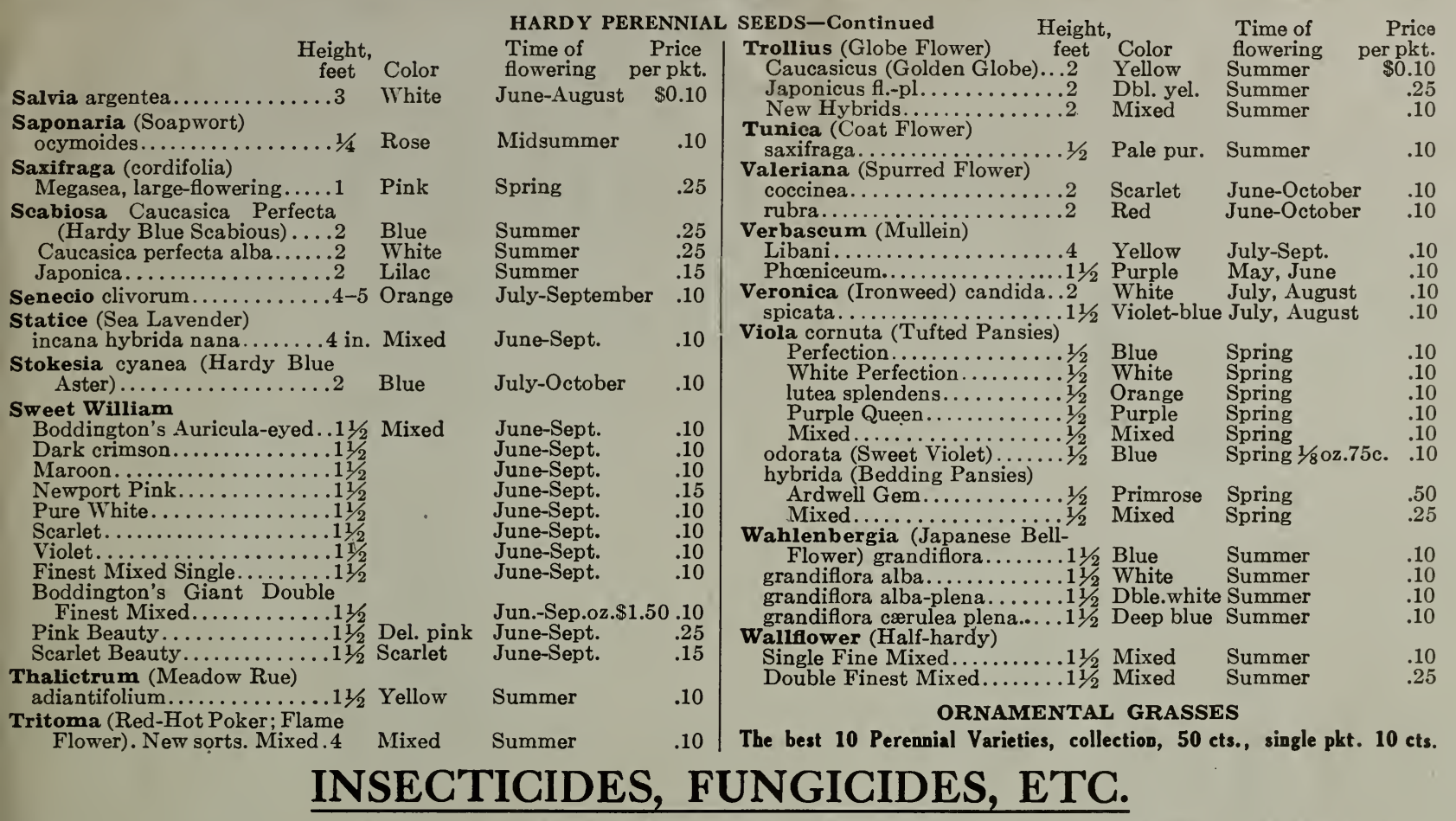

Aphine. $1 / 4$ pt. 25 cts., $1 / 2$ pt. 40 cts., pt. 65 cts., qt. $\$ 1.00$, gal. $\$ 3.00$. Aphis Punk. Carton, 12 rolls, 85 cts. (mail weight, $1 \mathrm{lb}$ ), case of 12 cartons $\$ 8.50$.

Arsenate of Lead Paste. 1-lb. tin 45 cts., 5 lbs. $\$ 2.00,121 / 2$ lbs. $\$ 4.15$, 25 lbs. $\$ 6.50,50$ lbs. $\$ 12.50,100$ lbs. $\$ 24.00$.

Asbestos Torches. Each 75 cts. (mail weight, without pole, 1 lb.), pole, 30 cts. extra.

Black-Leat 40. $1 / 2$-lb. tin, $\$ 1.00,2$ lbs. $\$ 3.25,10$ lbs. $\$ 13.75$.

Bordeaux, Dry. 1 -lb. box 55 cts., 5 lbs. $\$ 2.50,10$ lbs. $\$ 4.00$.

Bordeaux, Paste. Pt. 45 cts., qt. 75 cts., gal. $\$ 200,5$ gals. $\$ 8.50$.

Cut-Worm Killer. 1 lb. 30 cts. (parcel post weight, 2 lbs.), 5 lbs. tin $\$ 1.50$ (parcel post weight, 6 lbs.), 25 lbs. $\$ 5.00$.

Copper Solution, Ammoniated. Qt. \$1.15, gal. \$3.50.

Fish-Oil Soap. Lb. 30 cts. (mail weight 2 lbs.), 5 lbs. $\$ 1.40,10$ lbs. $\$ 2.60,25$ lbs. $\$ 6.75,100$ lbs. $\$ 25.00$.

Flowers of Sulphur. Lb. $15 \mathrm{cts}$. (mail weight $2 \mathrm{lbs}$.), $10 \mathrm{lbs} . \$ 1.00$, 25 lbs. and over at 8 cts. per lb.

Fungine. $1 / 2$ pt. 40 cts., pt. 65 cts., qt. $\$ 1.00$, gal. $\$ 3.50$.

Grape Dust. 5-lb. pkge. 85 cts. (mail weight 6 lbs.), 10 lbs. $\$ 1.60$, 25 lbs. $\$ 3.75,100-1 b$. keg $\$ 14.50$.

Hellebore Powder. 1-lb. box 80 cts., 2-lb. box $\$ 1.50,25$ lbs. $\$ 15.50$

Herbicide. Qt. 60 cts., gal. $\$ 1.75,2$ gals. $\$ 3.25,5$-gal. keg $\$ 7.00$. 10 -gal. keg $\$ 12.50,25$-gal. cask $\$ 27.50,48$-gal. bbl. $\$ 47.50$.

Imp Soap Spray. Qt. 65 cts., gal. $\$ 2.50,5$ gals. $\$ 11.25,10$ gals. $\$ 22.00$.

Kerosene Miscible Oil. Pt. 40 cts., qt. 65 cts., gal. $\$ 1.65,5$ gals. $\$ 6.00,50$ gals. $\$ 50.00$.

Key Weed (Weed Killer). Qt. 60 cts., gal. $\$ 1.75,5$ gals. $\$ 7.00$ 10 gals. $\$ 12.50,50$ gals. $\$ 47.50$.

Lemon Oil. $1 / 2$ pt. 40 c., pt. 60 c., qt. $\$ 1.00,1 / 2$ gal. $\$ 1.75$, gal. $\$ 3.00$.

Nico-Fume Tobacco Paper. 24 sheets (mail weight 1 lb.) $\$ 1.25$, 144 sheets (mail weight 4 lbs.), $\$ 5.00,288$ sheets, $\$ 9.50$.

Nico-Fume Liquid. $1 / 4$ lb. 65 c., lb. $\$ 2.00,4$ lbs. $\$ 7.50,8 \mathrm{lbs} . \$ 14.50$. Nicoticide. $1 / 4$ pt. 80 cts., $1 / 2$ pt. $\$ 1.25$, pt. $\$ 2.75$, qt. $\$ 5.00,1 / 2$ gal. $\$ 9.50$, gal. $\$ 18.00$.

Nikoteen. $1 / 4$ pt. 40 cts., $1-$ lb. bottle $\$ 1.50,10$ lbs. $\$ 14.00$.

Pyrox. Lb. 50 cts., 5 lbs. $\$ 2.00,10$ lbs. $\$ 3.50,25$ lbs. $\$ 6.75,50$ lbs. $\$ 12.25,100$ lbs. $\$ 23.00$.

Readeana. 8 ozs. 50 cts., 24 ozs. $\$ 1.25$, qt. $\$ 1.50$, gal. $\$ 4.50$.

Scalecide. Qt. 65 cts., gal. $\$ 1.60,5$ gals. $\$ 6.80,10$ gals. $\$ 11.70$, 30 -gal. bbl. $\$ 28.85$.

Slug-Shot. Lb. 20 cts. (mail weight, 2 lbs.), 5 lbs. 65 cts., 10 lbs. $\$ 1.10,125$ lbs. $\$ 13.00$.

Sodium Cyanide (Cyanegg). Lb. $\$ 1.50$.

Tobacco Dust. 5 lbs. 50 cts., 25 lbs. $\$ 1.50,100$-lb. bag $\$ 5.00$

Tobacco Stems. 100 -lb. bale $\$ 2.50,300$ lbs. $\$ 7.00$.

X-L-All Liquid Insecticide. Qt. $\$ 1.75,1 / 2$ gal. $\$ 3.25$, gal. $\$ 6.00$.

X-L-All Vaporizing Compound. $15 \mathrm{cts}$. cake, each cake sufficient for 1,000 cubic feet. Box of 80 cakes for $\$ 10.50$.

\section{Liquid Form}

No. $1, \$ 8.00$ bottle contains sufficient for 40,000 cubic feet of space. No. $2, \$ 5.00$ bottle contains sufficient for 20,000 cubic feet of space. No. $3, \$ 2.50$ bottle contains sufficient for 10,000 cubic feet of space. No. 4, $\$ 1.50$ bottle contains sufficient for 5,000 cubic feet of space.

\section{SPRAYERS, VAPORIZERS and}

\section{BELLOWS FOR APPLYING INSECTICIDES,}

Auto-Spray. When properly charged, holds three gallons of solution and one gallon of compressed air. The "Auto-Pop" Nozzle cannot clog. No continuous pumping; twelve strokes of the plunger will compress the air, and two pumpings will empty the entire contents. It works entirely automatically from six to fifteen minutes, according to the nozzle opening.

Auto-Spray, No. 1 B. Brass tank, with "Auto-Pop" Nozzle. $\$ 11.00$ Auto-Spray, No. 1 D. Galvanized tank, "Auto-Pop" Nozzle. 7.50

\section{EXTRA ATTACHMENTS}

Brass Strainer. Necessary for the proper preparation of

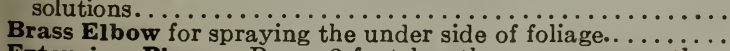
Brass Elbow for spraying the under side of foliage..........
Extension Pipes. Brass, 2 -foot lengths; as many as three can be used for reaching trees. Each length..............

Auto-Spray (Robinson's Hand). Galvanized pump and tank, $\$ 1.50$ each.

Auto-Spray (Robinson's Hand). Brass pump and tank, $\$ 2.50$ each.
Auto-Spray No. 5. Double acting (making a continuous spray), $\$ 5.50$ each.

Alpha Hand Sprayer. The premier English compressed-air Hand Sprayer. No. 3 (holds 4 qts.), $\$ 10.75$ each; No. 1 A (holds 2 qts.), $\$ 9.00$ each.

Sprayer, Muratori's Hand. Invaluable for spraying orchids and other plants hanging from the rafters of a greenhouse; $\$ 12.00$.

Vaporizer, Campbell's Sulphur. No. $1, \$ 7.00$ each; No. $2, \$ 8.50$ each. Glass Balls, per box of 6,15 cts. Yellow Powder, per tin, 20 cts. Hollow or Solid Wicks, 15 cts. each. Each Vaporizer for Tobacco Extracts ..................\$0.75

$\mathbf{X}$-L-All Vaporizer. Lamp and stand complete......... 1.75

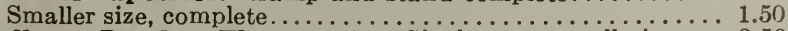

Bellows, Powder, Woodason's. Single-cone, small size..... 2.50 Single-cone, large size........................ 3.50

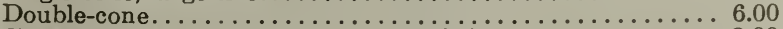

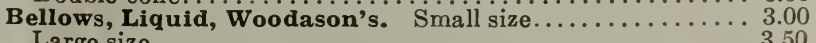


Boxes, Cutflower Cardboard. Manilla or Mist Gray color. Regular weight.

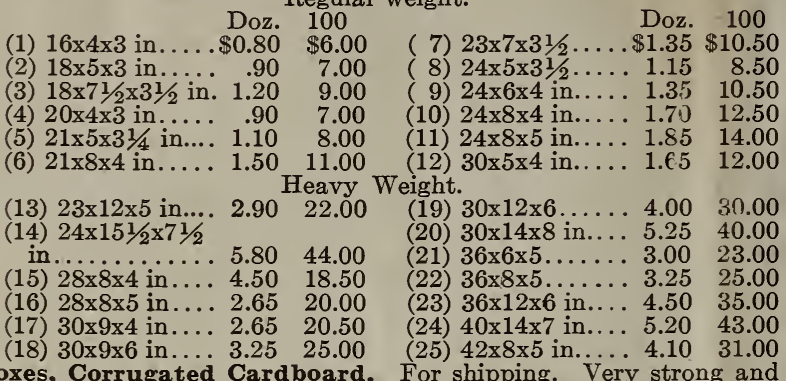

Boxes, Corrugated Cardboard. reinforced. Shipped flat.

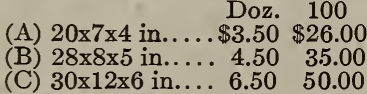

(D) $36 \times 14 \times 8$ in . . $\$ 7.75$, 100

(D) $36 \times 14 \times 8$ in $\ldots \$ 7.75 \$ 60.00$

(E) $42 \times 13 \times 6$ in ... $8.75 \quad 79.00$

$\begin{array}{llll}\text { (C) } 30 \times 12 \times 6 \text { in ... } 6.50 & 50.00 & \text { (F) } 48 \times 18 \times 8 \text { in ... } 10.50 \quad 80.00\end{array}$ Boxes, Leatheroid, for Shipping Cut-Flowers. Very strong.

Flower-Pots. Sizes, height and width inside.

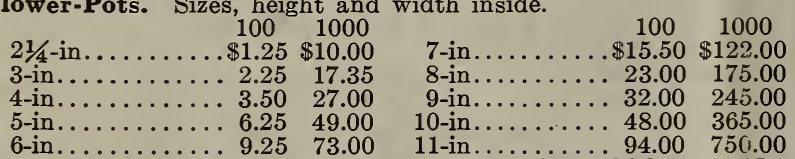

Glazing Points, Peerless. No. 1, for small, single-thick glass; No. 2 , for medium, double-thick glass; No. $2 \frac{1}{2}$, for large, doublethick and skylight glass. 70 cts. per 1000 .

Glazing Points, Siebert's. Made of zinc and will not rust. Two sizes $5 / 8$ and $7 / 8$ inch long. 50 cts. per lb.

Grape Protecting Bags. They protect fruit from insects, rust, etc. $\begin{array}{rrrr}100 & 1000 & & 100 \\ \text { No. 2. Small.....\$0.75 } \$ 6.50 & \text { No. 3. Medium.... } \$ 0.90 & \$ 8.00\end{array}$ No. 4. Large...................... 1.009 .00

Melon Nets. Imported. $\$ 4.00$ per doz., $\$ 35.00$ per 100 .

Sprinklers, Scollay, Straight-neck. Large, $\$ 1.50$; small, 75 . cts. Angle-neck, $\$ 1.50$.

Summer Cloud. A greenhouse shading, 1/2-lb. pkt. 50 cts.

Tubs, Boddington's Cedar Plant-(With feet, $\$ 1.50$ extra). Outside top Outside Outside top Outside

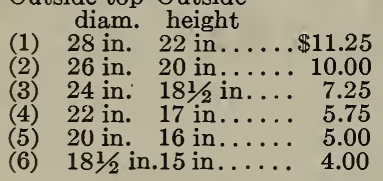

(7) 17 in. 14 in....

(8) 16 in. 13 in.

(10) 12 in. $91 / 2$ in.

(11) $101 / 2$ in. 9 in...

(12) $91 / 2 \mathrm{in} .8 \mathrm{in}$.

(13) 8 in. 7 in

STAKES AND PLANT SUPPORTS

Bamboo Canes, Chinese. Very strong and heavy. $100 \quad 1000$ $4 \mathrm{ft}$. , heavy....... $\$ 2.25 \$ 19.00$

$6 \mathrm{ft}$. , heavy. $\$ 3.50 \$ 28.00$

$5 \mathrm{ft}$., heavy....... $3.00 \quad 24.00$

Bamboo Canes, Japanese. Painted green.

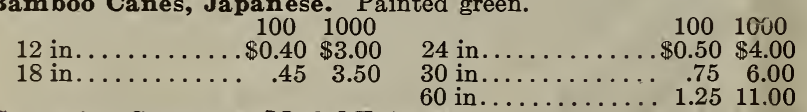

Carnation Supports, Model Extension

Two-ring, doz. $\$ 1.25 ; 100 \$ 8.00$. Three-ring, doz. $\$ 1.50 ; 100 \$ 10.00$ Stakes, Galvanized Wire. No. 8 wire.

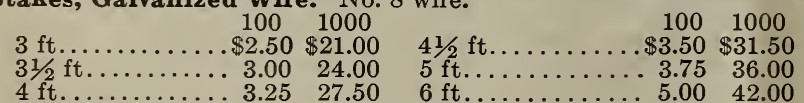

Labels, Wooden, Pot or Garden-Plain $4 \ldots \ldots \ldots \ldots .5 .0042 .00$

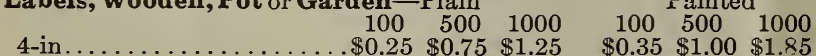

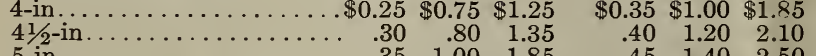

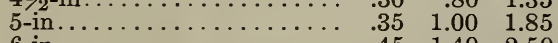

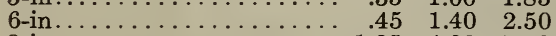

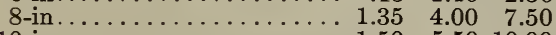

10 -in

$\begin{array}{lll}1.50 & 5.50 & 10.00\end{array}$

$\begin{array}{ccc}1.75 & 6.50 & 12.00\end{array}$

$\begin{array}{lllllll}\text { Copper Wired-31/2-in... } & .30 & 1.20 & 2.00 & .40 & 1.50 & 2.50\end{array}$

Lever Clip, Blake's. For fastening rose wires to stakes. $\$ 1.00$ per box (500 to the box), $\$ 1.75$ per 1000 .

Raffia, White. 50c. per lb. Green. $\$ 2.00$ per lb.
Baskets, Bamboo, Garden. Light and very strong. Splint bottom, handles over. Galvanized strapped. Six in bundle.

No. Each Doz. No. Nach Doz.

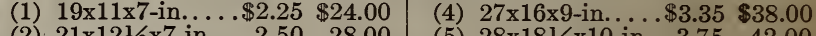

(2) $21 \times 121 / 2 \times 7-$ in... 2.5028 .00

(3) $251 / 2 \times 141 / 2 \times 8$-in. 3.0032 .00

(5) $28 \times 18 \frac{1}{2} \times 10$-in.. $3.75 \quad 42.00$

Silkaline. Very largely used for tying. Three sizes, fine, medium and coarse, F, FF and FFF. 50 cts. per spool, $\$ 3.50$ per box of 8 spools.

\section{RUBBER HOSE, NOZZLES, ETC.}

Boston Graduating Nozzle. Throws a coarse or fine spray, or a solid stream. $3 / 4$-in. $75 \mathrm{cts}$. each.

Boston Rose Hose Sprinkler. A wide-face Nozzle, like the rose of a watering pot. 3 -in. face, $\$ 1.25$ each; 4 -in. face, $\$ 1.50$ each.

Stott Sprayer. Single-spray $\$ 1.50$ each; double-spray $\$ 2.50$ each.

Hose, Rubber, Boddington's "Rainbow." Cut any length desired and fitted with couplings. $3 / 4$-in. $25 \mathrm{cts}$. per ft.; $1 / 2$-in. $22 \mathrm{cts}$. per $\mathrm{ft}$.

Hose Menders, Cooper's. 1/2-in. and 3/4-in. $\$ 1.20 \mathrm{per} \mathrm{doz}$.

Kinney Pump. For distributing liquid manure $\$ 2.50$ each.

Watering Pots, Haw's Pattern-

No.0.3 qts.; shelf; 9 -in. spout, No. 4.8 qts.; jap.; 2 roses. . . . $\$ 6.00$ 1 pot rose and extra joint. $\$ 3.75$ No. 5.10 qts.; japanned; 1

No. 1.3 qts.; jap.; 2 roses... . 4.00 rose and spreader....... 6.50

No. 2.4 qts.; jap.; 2 roses.... 4.50 No. 6.12 qts.; japanned; 1

No. 3.6 qts.; jap.; 2 roses.... 5.00 rose and spreader..... 7.75

THERMOMETERS-Mushroom-bed. $\$ 3.50$ each.

Japanned. Tin case, 10 - and 12 -in., $85 \mathrm{cts}$. and $\$ 1.00$ each.

Self-registering (Maximum and Minimum), $\$ 5.00$.

FERTILIZERS, CHARCOAL, MOSS, ETC.

Ashes, Canada Hardwood. Bbl. of about $200 \mathrm{lbs}$., $\$ 5.50$, ton of 2,000 lbs. in bbls., $\$ 50.00$.

Blood, Dried (16\% Ammonia). 10 lbs. $\$ 1.50,50$ lbs. $\$ 6.00,100$ lbs. $\$ 10.00$.

Blood and Bone (Tankage High Grade,) $9 \%$ Ammonia, $15 \%$ B. P. L. 50 lbs. $\$ 4.50,100$ lbs. $\$ 8.00,200$ lbs. $\$ 15.00$, ton $\$ 145.00$.

Blood and Bone (Tankage Regular Grade), 6\% Ammonia, 30\% B.P.L. 50 lbs. $\$ 2.50,100$ lbs. $\$ 4.50,200$ lbs. $\$ 8.00$, ton $\$ 78.00$.

Bone Dust for Quick Action. 5 lbs. 40 cts., 10 lbs. 75 cts., 25 lbs. $\$ 1.40,50$ lbs. $\$ 2.25,100$ lbs. $\$ 4.25$, ton $\$ 75.00$.

Bone Meal for General Use. 5 lbs. 40 cts., $10 \mathrm{lbs}$. 75 cts., $25 \mathrm{lbs}$. $\$ 1.50,50$ lbs. $\$ 2.75,100$ lbs. $\$ 5.00$, ton $\$ 80.00$.

Bone Meal for Roses. 5 lbs. 50 cts., 10 lbs. 90 cts., 25 lbs. $\$ 2.00$, 50 lbs. $\$ 3.25,100$ lbs. $\$ 6.00$, ton $\$ 100.00$.

Bone, Crushed, Coarse. About $1 / 4$ to $1 / 2$-in. pieces, $5 \mathrm{lbs} .50 \mathrm{cts}$., 10 lbs. 90 cts., 25 lbs. $\$ 1.75,50$ lbs. $\$ 3.00,100$ lbs. $\$ 5.25$, ton $\$ 98.00$. Guano, Ichthemic. An ideal plant food. $28 \mathrm{lbs} \$ 4.00,56 \mathrm{lbs}$. $\$ 7.00,112$ lbs. $\$ 13.00$.

Land Plaster. In 200 -lb. bags only. Bag, $\$ 2.50$, ton $\$ 19.50$.

Odorless Lawn Top Dressing. 5 lbs. 40 cts., 10 lbs. 70 cts., 25 lbs. $\$ 1.40,50$ lbs. $\$ 2.25,100$ lbs. $\$ 4.50,500$ lbs. $\$ 19.00$, ton $\$ 75.00$.

Phosphate Acid. In 200 -lb. sacks only, $\$ 5.00$, ton $\$ 40.00$.

Lime, Agricultural, Hydrated. In 100-lb. bags only. $100-1 \mathrm{~b}$. bag $\$ 1.50,500$ lbs. $\$ 6.50$, ton $\$ 24.00$. In lots of 3 tons or over, $\$ 20.00$ per ton; carload lots, $\$ 18.00$ per ton, f.o.b. New York.

Limestone, Pulverized. Apply two tons to the acre. Put up in 100 -lb. bags, $\$ 1.50,500$ lbs. $\$ 6.00,1000 \cdot$ lbs. $\$ 11.00$, ton $\$ 20.00$. In carload lots, in bags, f.o.b. works, $\$ 18.00$ per ton. In car lots in bags, the bags are returnable at $20 \mathrm{cts}$. each, delivered back to the works. This makes net cost of $\$ 14.00$ per ton.

Nitrate of Soda. 100 to 300 lbs. per acre. Lb. 25 cts., 5 lbs. 80 cts., 10 lbs. $\$ 1.50,25$ lbs. $\$ 3.00,50$ lbs. $\$ 5.50,100$ lbs. $\$ 10.00$.

Nitraco. Substitute for Clay's Fertilizer. 25 lbs. $\$ 2.50,50 \mathrm{lbs}$. $\$ 4.50,100$ lbs. $\$ 8.00,200$ lbs. $\$ 15.00$; ton $\$ 100.00$.

Scotch Soot (Imported). Sold in 100-lb. bags only, $\$ 6.00$ per bag.

Sheep Manure, Unleached. 5 lbs. 45 cts., $10 \mathrm{lbs}$. 75 cts., 100-lb. bag, $\$ 4.00,500$ lbs. $\$ 17.00,1000$ lbs. $\$ 32.00$, ton $\$ 60.00$.

Sulphate of Ammonia (25\% Ammonia, $20 \%$ Nitrogen). 50 lbs. $\$ 5.00,100$ lbs. $\$ 9.00,200$ lbs. $\$ 17.00$, ton $\$ 160.00$.

Thomson's "Special" Chrysanthemum Manure. 28-lb. bag $\$ 7.00,56$-lb. bag $\$ 11.00$,

Thomson's Vine, Plant and Vegetable Manure. 28-lb. bag $\$ 3.50,56$-lb. bag $\$ 6.50,112$-lb. bag $\$ 12.00$.

Charcoal. Per bag of 50 lbs. $\$ 2.25,100$ lbs. $\$ 4.00,1000$ lbs. $\$ 38.00$, ton $\$ 75.00$.

Cocoanut Fiber. 5 lbs. 25 cts., 25 lbs. $\$ 1.00,50$ lbs. $\$ 1.50,100$ lbs. $\$ 2.50$.

Leaf-Mold. Used for preparing Rhododendron beds. Bbl. $\$ 3.50$. Moss, Live Green Sphagnum. Freshly gathered. Bbl. $\$ 3.50$.

Moss, Dry Sphagnum. Large bale $\$ 3.00$.

Moss, Sheet, Natural Green. For covering the pots or tubs of large plants. Bag (10 lbs.) $\$ 5.00$.

Peat (Osmundi). For orchids. Bbl. $\$ 3.00$.

Peat, Rotted, Fibrous. For mixing with potting soil. Bbl. $\$ 2.50$. 